\title{
Patterns and Processes of Alteration in the Lavas and Dykes of the Troodos Ophiolite, Cyprus
}

\author{
KATHRYN M. GILLIS ${ }^{1}$ AND PAUL T. ROBINSON
}

\author{
Department of Geology and Center for Marine Geology, Dalhousie University, Halifax, \\ Nova Scotia, Canada
}

\begin{abstract}
Alteration patterns in the lavas and dykes of the Troodos Ophiolite, Cyprus, record a complex history of axial hydrothermal alteration, crustal aging, and subsequent uplift and emplacement of the ophiolite. Field mapping shows that distribution of five alteration zones, each with distinct mineralogical, geochemical, and hydrologic characteristics, is influenced by igneous stratigraphy, structure, and the nature and thickness of the overlying sediments. Paragenetic sequences of secondary minerals indicate that alteration conditions changed progressively as the crust cooled and moved off-axis. Along spreading axes, low temperatures $\left(\leq 50^{\circ} \mathrm{C}\right)$ were maintained by the rapid flow of seawater in and out of the lavas, and only minimal alteration took place. In contrast, lower water/rock ratios and higher temperatures $\left(>200^{\circ} \mathrm{C}\right)$ in the dykes promoted extensive seawater-rock interaction. Although the sharp rise in temperature between the two regimes generally coincides with the lava-dyke transition, late-stage intrusions or hydrothermal upwelling zones locally cause high-temperature alteration to extend upward into the lavas. As a segment of crust moved off-axis, temperatures remained low in the lavas and progressively decreased, from $>250^{\circ}$ to $<80^{\circ} \mathrm{C}$, in the dykes. High permeability in the uppermost lavas led to the downward migration of an oxidative alteration front whose thickness and spatial distribution was dependent upon the rate and nature of sedimentation and, thus, the original seafloor morphology. Although field relations show that alteration has a consistent vertical pattem in Troodos, the alteration zones are not laterally continuous, and the stratigraphic depth of their boundaries varies considerably.
\end{abstract}

\section{INTRODUCTION}

Early studies of the massive sulfide deposits [Constantinou and Govett, 1973] and alteration patterns within the Troodos ophiolite [Gass and Smewing, 1973] contributed greatly to the development of models for oceanic hydrothermal systems [Spooner et al., 1977; Chapman and Spooner, 1977] and subseafloor metamorphism [Coleman, 1977]. Subsequent discovery of high-temperature vents at mid-ocean ridges [e.g., Edmond et al., 1979], seamounts [Malahoff et al., 1982], and back arc basins [Horbie et al., 1986] showed that hydrothermal circulation is a fundamental process in many oceanic environments.

Mineralogical and chemical zonations within the Troodos massive sulfide ore deposits indicate that they formed from hydrothermal fluids whose compositions were remarkably similar to those venting on the seafloor today [Adamides, 1987; Herzig and Friedrich, 1987; R ichards et al., 1989]. Fluid compositions in Troodos were buffered by epidosites at conditions similar to those inferred for the root-zones of active systems at mid-ocean ridges [Bowers and Taylor, 1985; Richardson et al., 1987; Schiffman et al., 1987; Schiffman and Smith, 1988; Seyfried et al., 1988; Von Damm, 1988]. Because of these and other similarities, the upflow zones of the Troodos hydrothermal systems are thought to be ancient analogues of modern active systems [Oudin and Constantinou, 1984].

Drilling of in situ oceanic crust has revealed vertically zoned alteration patterns in layer 2 [e.g., Bohlke et al., 1981; Alt and Honnorez, 1984]. Alteration is generally pervasive in the upper few tens of meters of basement whereas the underlying rocks are variably altered [Honnorez, 1981]. The alteration

\footnotetext{
${ }^{1}$ Now at Department of Geology and Geophysics, Woods Hole Oceanographic Institution, Woods Hole, Massachusetts.
}

Copyright 1990 by the American Geophysical Union. profile at Deep Sea Drilling Project (DSDP) hole 504B suggests that the transition from the lavas to sheeted dykes marks an abrupt change in alteration conditions, from low to high temperatures and high to low water/rock conditions [Alt et al., 1986a]. Vertical zonation of alteration has also been described for the Sarmiento [Stern and Elthon, 1979], Macquarie Island [Cocker et al., 1982], Samail [Gregory and Taylor, 1981; Nehlig and Juteau, 1988], Del Puerto [Evarts and Schiffman, 1983], Josephine [Harper et al., 1988; Zierenberg et al., 1988] and Troodos ophiolites [Gass and Smewing, 1973]. Of these, Troodos and Macquarie Island are the only ophiolites where low-temperature alteration is preserved [Gass and Smewing, 1973; Gillis and Robinson, 1985]. In most ophiolites, low temperature alteration assemblages have been overprinted either by metamorphism associated with emplacement (e.g., Josephine [Harper et al., 1988]) or by conductive reheating of the crust due to rapid deposition of a continuous cover of impermeable sediments (e.g., Samail [Alabastar and Pearce, 1985]).

The present study was undertaken as part of a major reinvestigation of the Troodos ophiolite by the Cyprus Crustal Study Group (CCSG). A drilling program sampled a nearly complete section from the top of the extrusive sequence to the lower part of the plutonic sequence in three holes. In addition, the stockwork zones of two massive sulfide deposits were sampled in holes CY2 and CY2A [Robinson et al., 1987]. Studies of these cores [Robinson et al., 1987, 1990] and associated outcrops [Gillis and Robinson, 1985; Baragar et al., 1987; Schiffman et al., 1987; Richardson et al., 1987] have shown that regional metamorphic zones are not appropriate to describe hydrothermal alteration in Troodos. Rather, several laterally discontinuous zones are recognized with alteration characteristics similar to those found in DSDP basement cores [Gillis and Robinson, 1988].

In this paper, we present the results of an integrated field, mineralogical, and geochemical study of alteration within the extrusive sequence and sheeted dyke complex of the Troodos ophiolite. Complementary studies of the lava stratigraphy and geochemistry [Bailey, 1984; Mehegan, 1988] allowed us to 
investigate variations in alteration on a cooling unit to regional scale. Our purpose is to develop a spatial and temporal model that describes the formation of alteration zones in Troodos and provides some insights into processes which influence the nature of alteration in oceanic crust.

\section{GEOLOGICSETTING}

The Troodos ophiolite lies at the northwest end of a belt of Cretaceous ophiolites that are discontinuously exposed along the margin of the Arabian plate [Moores et al., 1984]. Although the extensive sheeted dyke complex is unequivocal evidence for a spreading origin [Moores and Vine, 1971], lava compositions suggest formation in an arc or fore-arc environment [Miyashiro, 1973; Robinson et al., 1983; Moores et al., 1984; Thy et al., 1985; Rautenschlein et al., 1985; Mehegan, 1988].

The Troodos ophiolite crops out in an elongate domal structure in south-central Cyprus. Tertiary uplift and erosion of the ophiolite [Robertson, 1977] has produced the annular outcrop pattern with the ultramafic rocks exposed in the central Troodos mountains and the extrusive rocks along the periphery of the massif. Tectonized ultramafic rocks, at the base of the igneous sequence, are overlain successively by ultramafic cumulates, layered gabbros, and isotropic gabbros [George, 1978]. The boundary between the gabbros and the overlying sheeted dykes is both structural and intrusive [Malpas et al., 1987]. The lava-dyke transition is gradational but generally occurs over a $100-200 \mathrm{~m}$ interval. Marine sedimentary rocks that overlie the lavas are Campanian to Miocene in age [Bear, 1960]. Radiolarian fauna in the basal Perapedhi Formation [Blome and Irwin, 1985] and U-Pb zircon ages from the plagiogranites [Mukasa and Ludden, 1987] indicate that the ophiolite formed during the Turonian (88.5-91.5 Ma [Hartland et al., 1982]).

Alteration in the lavas and dykes is related to both axial hydrothermal systems [Spooner et al., 1977; Constantinou, 1980; Schiffman and Smith, 1988; Richards et al., 1989] and crustal aging [Gillis and Robinson, 1985] in a submarine environment. Isotopic and fluid inclusion data [Chapman and Spooner, 1977; Heaton and Sheppard, 1977; Spooner et al.,
1977; Barriga et al., 1987] show that seawater-derived solutions penetrated at least to the base of the plutonic sequence. High-temperature secondary phases in the plutonic and cumulate rocks imply alteration close to a ridge axis; however, the relationship of this alteration to higher-level oreforming hydrothermal systems has not been established. Troodos lacks a pervasive, emplacement-related metamorphic overprint evident in many other ophiolites (e.g., Josephine [Harper et al., 1988]). Deposition of palygorskite and gypsum in the upper few hundred meters of the lava pile during or after the Miocene [Staudigel et al., 1986; Staudigel and Gillis, 1991] is the only evidence to date for emplacement-related alteration.

\section{FIELD AREA, SAMPLING PROGRAM, AND ANALYTICAL METHODS}

Our study area includes the region along the northern flank of the ophiolite between the villages of Peristerona and Margi (Figure 1), extending from the top of the lava pile to the transition between the lavas and sheeted dykes. Several continuous stratigraphic sections, exposed along river sections and road-cuts, were studied in detail as were the CCSG drillcores from holes CY1, CY1A, CY2, and CY2A [see Robinson et al., 1987]. Reconnaissance mapping in the intervening areas showed that the studied sections are representative of the regional alteration patterns.

Secondary mineral assemblages were determined through the examination of more than 500 thin sections, $X$ ray diffraction analyses of over 700 samples, and microprobe analyses of approximately 200 polished thin sections. X ray diffraction analyses were carried out on air-dryed smear mounts of monomineral or multimineral samples which were scanned from 3 to $50^{\circ} 2 \varnothing$ using a Phillips X ray diffractometer. Clayrich samples were treated with ethylene glycol and rescanned to identify the smectite minerals. Selected samples were heated at $500^{\circ} \mathrm{C}$ for 2 hours, cooled slowly, and rescanned. Mineral analyses were obtained with a fully automated JEOL JXA-50A wavelength dispersive microprobe at Memorial University of Newfoundland, a JEOL 733 microprobe at Dalhousie University, and a MARKV Cambridge EDS microprobe at Dalhousie. To minimize loss due to volatization in hydrous

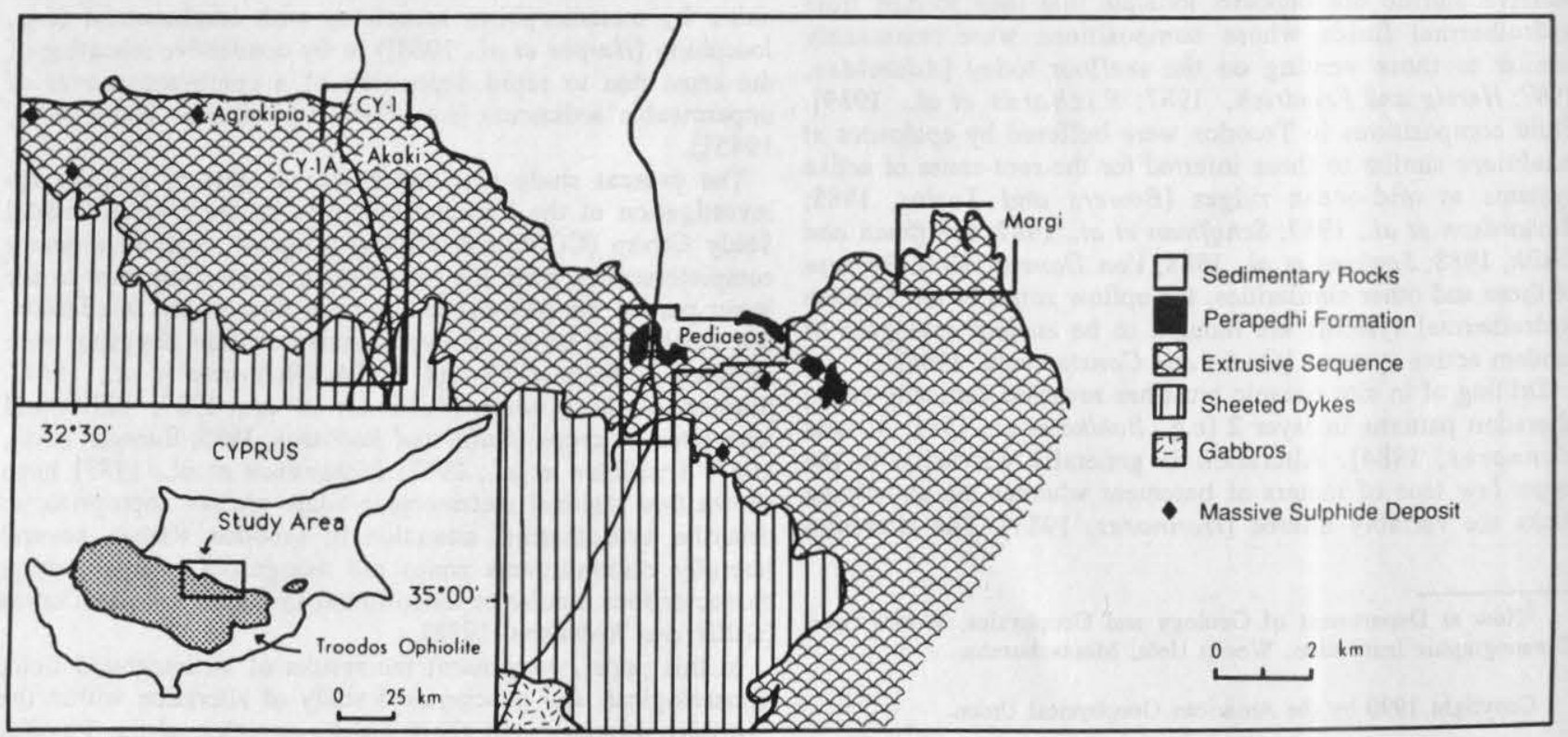

Fig. 1. Simplified geologic map of the northeastem portion of the Troodos ophiolite. Areas studied in detailed are outlined and the Cyprus Crustal Study Group drill sites are shown. 
phases, $\mathrm{Na}, \mathrm{Ca}$, and $\mathrm{K}$ were analyzed first and counted for $10 \mathrm{~s}$ on the wavelength dispersive systems.

Due to the high volatile content of most of the secondary phases and the heterogeneity of the clay minerals, the quality of the microprobe data is difficult to access. Structural formulas were calculated for all minerals; if these were stoichiometric, the analyses were deemed good. Structural formulas for the clay minerals were calculated following the method of Ross and Hendricks [1945].

Bulk rock compositions were determined for 350 samples collected as part of an integrated sampling program by the Cyprus Crustal Study Group (see Robinson et al. [1991]). Major elements were measured at the Geological Survey of Canada (XRF) and Memorial University (AA). Interlab variation is $<3 \%$ for elements $>10 \mathrm{wt} \%,<6 \%$ for elements between 10 and $2 w t \%$, and $<7 \%$ for elements $<2$ wt $\%$. Trace elements were measured at Memorial (XRF). $\mathrm{CO}_{2}$ and $\mathrm{H}_{2} \mathrm{O}$ were measured by $\mathrm{C}-\mathrm{H}-\mathrm{N}$ gas chromotography and ferric iron by titration at the Geological Survey of Canada (CY1) and L'Univeristé de Montréal (CY1A).

Zeolites, clay minerals, and carbonates were separated from vesicles, vugs, and veins for stable isotope analysis. $\delta^{18} \mathrm{O}$ and ${ }^{13} \mathrm{C}$ contents of carbonates were determined by the $\mathrm{CO}_{2}$ gasphosphoric method [McCrea, 1950] using a VG Micromass 602D "online" mass spectrometer at Dalhousie University. The $\delta^{18} \mathrm{O}$ contents of silicate minerals were determined by the $\mathrm{BrF}_{5}$ method [Clayton and Mayeda, 1963; Muehlenbachs and Clayton, 1972] at the University of Alberta. All results are reported as delta $(\delta)$ notation relative to the SMOW standard [Craig, 1957].

The ${ }^{87} \mathrm{Sr} /{ }^{86} \mathrm{Sr}$ ratios of whole rock powders were measured using a modified NBS 12 inch radius mass spectrometer at L'Université de Montréal following the method of Machado et al. [1986]. The ${ }^{87} \mathrm{Sr} /{ }^{86} \mathrm{Sr}$ ratios are normalized to ${ }^{86} \mathrm{Sr} /{ }^{88} \mathrm{Sr}$ $=0.1194$ and 0.70800 for the Eimer and Amend standard.

\section{RESULTS}

\section{Alteration Zones}

Introduction. Five alteration zones are recognized in the lavas and dykes based on secondary mineral assemblages and field appearance (Table 1; Figure 2)[Gillis and Robinson, 1988]: a seafloor weathering zone, a low-temperature zone, a transition zone, an upper dyke zone, and a mineralized zone.

The seafloor weathering zone is characterized by pervasive oxidative alteration and an abundance of interpillow calcareous sediment. Thick glassy pillow margins and interpillow hyaloclastite are pervasively altered to mixtures of green smectite, Fe-hydroxide, phillipsite, analcime, and calcite. Yellowish brown pillow margins, which owe their color to the concentration of Fe-hydroxides, grade into greyish green to greenish grey pillow interiors. Original groundmass textures

TABLE 1. Characteristics of the Alteration Zones

\begin{tabular}{|c|c|c|c|c|}
\hline Zone* & Phenocryst Minerals & Groundmass & Glassy Margins & Void-filling $^{\dagger}$ \\
\hline SWZ & $\begin{array}{l}\text { oliv } \rightarrow \text { goet + calc (T) } \\
\text { cpx } \rightarrow \text { smec (F-M) } \\
\text { spinel (F) }\end{array}$ & $\begin{array}{ll}\text { cpx } \rightarrow & \text { smec }(\mathrm{S}) \\
\text { plag } \rightarrow & \text { smec }(\mathrm{S}-\mathrm{M}) \\
\text { plag } \rightarrow & \mathrm{K}-\mathrm{spar}(\mathrm{T}) \\
\text { timag } \rightarrow & \text { maghem }(\mathrm{S}-\mathrm{M}) \\
\text { mesos } \rightarrow \text { smec, calc }(\mathrm{M}-\mathrm{T})\end{array}$ & smec + phil (T) & $\begin{array}{l}\text { 1. } \text { smec }+ \text { Fe hydro } \\
\text { 2. anal, adularia } \\
\text { 3. calc } \\
\text { 4. paly }\end{array}$ \\
\hline LTZ & $\begin{array}{l}\text { oliv } \rightarrow \text { goet }+ \text { calc }(\mathrm{T}) \\
\text { cpx } \rightarrow \text { smec (F-S) } \\
\text { plag } \rightarrow \text { smec, celad, } \\
\quad \text { calc (F-M) } \\
\text { spinel (F) } \\
\text { timag (F) }\end{array}$ & $\begin{aligned} \begin{aligned} \text { cpx } \rightarrow & \text { smec }(\mathrm{S}) \\
\text { plag } \rightarrow & \text { smec, celad, } \\
& \text { calc (F-M) }\end{aligned} \\
\text { timag } \rightarrow \text { maghem (S-M) } \\
\text { mesos } \rightarrow \text { smec, celad, } \\
\text { calc }(\mathrm{M}-\mathrm{T})\end{aligned}$ & $\begin{array}{l}\text { 1. smec + phil } \\
+ \text { anal } \\
\text { 2. smec + celad } \\
+ \text { clino }\end{array}$ & $\begin{array}{l}\text { 1. smec + celad } \\
\text { 2. Na-Ca zeolites, } \\
\text { qtz, chal } \\
\text { 3. calc } \\
\text { 4. paly }\end{array}$ \\
\hline $\mathrm{TZ}$ & $\begin{array}{l}\text { cpx } \rightarrow \text { smec, sm/chl (S-M) } \\
\text { plag } \rightarrow \text { albite }(\mathrm{M}-\mathrm{T}) \\
\text { timag }(\mathrm{F})\end{array}$ & $\begin{array}{l}\text { cpx } \rightarrow \text { smec, smec/chl }(\mathrm{S}-\mathrm{M}) \\
\text { plag } \rightarrow \text { smec, smec/chl }(\mathrm{S}-\mathrm{M}) \\
\text { plag } \rightarrow \text { albite }(\mathrm{T}) \\
\text { timag }(\mathrm{F}) \\
\text { mesos } \rightarrow \text { smec, smec/chl, } \\
\qquad \text { qtz (M-T) }\end{array}$ & $\begin{array}{l}\text { smec + smec/chl } \\
\text { + laum + qtz + pyr }\end{array}$ & $\begin{array}{l}\text { 1. smec }+ \text { smec/chl } \\
\text { 2. laum }+q t z+p y r \\
\text { 3. calc }\end{array}$ \\
\hline UDZ & $\begin{array}{l}\text { cpx } \rightarrow \text { chl }(\mathrm{S}-\mathrm{M}) \\
\text { plag } \rightarrow \text { albite }(\mathrm{T}) \\
\text { plag } \rightarrow \text { calc, epi, chl (M-T) }\end{array}$ & $\begin{array}{c}\text { cpx } \rightarrow \text { chl }(\mathrm{S}-\mathrm{M}) \\
\text { plag } \rightarrow \text { albite }(\mathrm{T}) \\
\text { plag } \rightarrow \text { epi }+ \text { chl }(\mathrm{M}-\mathrm{T}) \\
\text { timag } \rightarrow \text { sphene }(\mathrm{S}-\mathrm{M}) \\
\text { mesos } \rightarrow \text { chl, qtz, epi, } \\
\quad \text { pyr }(\mathrm{T})\end{array}$ & $\begin{array}{c}\text { chl }+ \text { qtz }+ \text { pyr } \\
+ \text { epi }\end{array}$ & $\begin{array}{l}\text { 1. chl }+ \text { epi }+q t z \\
\quad+\text { pyr } \\
\text { 2. qtz }+ \text { pyr } \\
\text { 3. calc }\end{array}$ \\
\hline MZ\# & $\begin{array}{l}\text { plag } \rightarrow \text { ill }+ \text { qtz }(T) \\
\text { timag } \rightarrow \text { sphene }(T)\end{array}$ & $\begin{array}{c}\text { mesos } \rightarrow \text { chl }+q t z+ \\
\text { pyr }+ \text { sphene }(T)\end{array}$ & $\mathrm{chl}+\mathrm{qtz}+\mathrm{pyr}$ & $\begin{array}{l}\text { 1. jasper pyr } \\
+q u \\
\text { 2. pyr + chal } \\
+ \text { pyrh }\end{array}$ \\
\hline
\end{tabular}

F, fresh; S, slightly altered; M, moderately altered; T, totally altered; oliv, olivine; cpx, clinopyroxene; plag, plagioclase; Timag, titanomagnetite; mesos, mesostasis; smec, smectite; celad, celadonite; chl, chlorite; smec/chl, mixed-layer smectite/chlorite; paly, palygorskite; $\mathrm{Fe}$ hydro, $\mathrm{Fe}$ hydroxides; goet, goethite; maghem, maghemite; calc, calcite; anal, analcime; phil, phillipsite; clino, clinoptilolite; laum, laumontite; epi, epidote; chal, chalcedony; qtz, quartz; pyr, pyrite; chalco, chalcopyrite; pyrnh, pyrrhotite; ill, illite; K-spar, potassium feldspar.

*SWZ, seafloor weathering zone; LTZ, low-temperature zone; TZ, transition zone; UDZ, upper dike zone; MZ, mineralized zone.

$\dagger$ Numbers indicate order of deposition, from oldest to youngest.

\# Summarized from Constantinou and Govette [1973], Constantinou [1980], and Lydon [1984]. These characteristics generally describe the zone of most intense alteration and mineralization in the MZ; for details of specific deposits, see original references. 


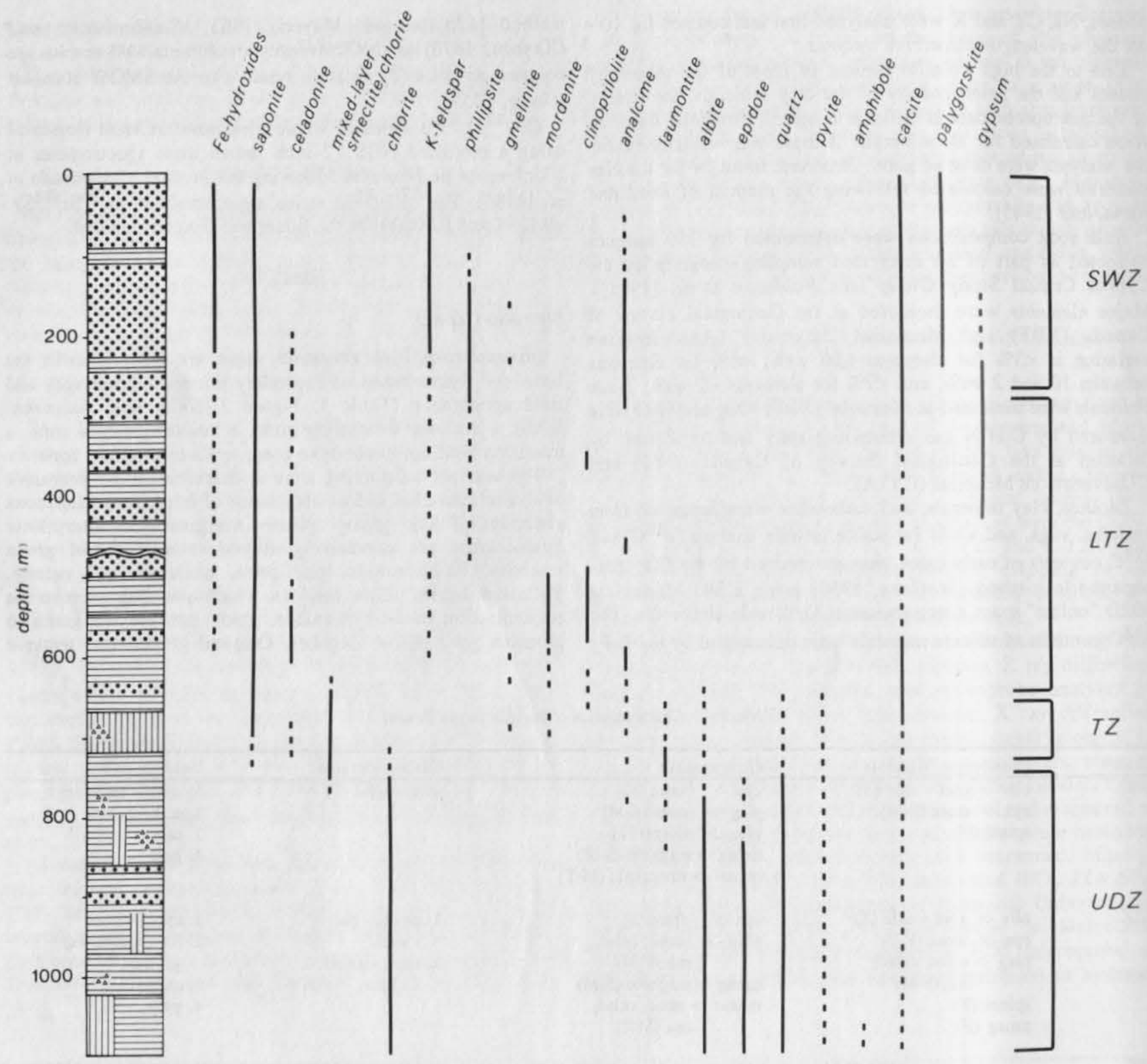

Fig. 2. Distribution of secondary minerals in holes CY1/1A. Stratigraphic column on the left shows the major lithologic units: small dots represent pillows; horizontal lines, massive and sheet flows; vertical lines, dykes; triangles, breccias and hyaloclastites. Alteration zones are outlined on the right. Solid vertical lines indicate the phase is located throughout the unit; dashed lines indicate the phase is locally present. Zone abbreviations are given in Table 1.

are commonly preserved but may be obscured by the reddish brown, fibrous to amorphous smectite which replaces the mesostasis; concentration of this clay mineral within segregation vesicles commonly gives the rocks a spotted appearance.

Several episodes of secondary mineral deposition are recognized from cross-cutting relations and precipitation sequences within filled voids. The following generalizations may be made: (1) smectite mixed with Fe-hydroxides was the earliest phase to form (Figure $3 a$ ); (2) in some samples, zeolites and adularia line voids and project inward toward open cavities; (3) calcite was deposited in re-opened or cross-cutting veins (Figure $3 a$ ). Successive layers of euhedral calcite crystals, mantled by a light dusting of smectite, indicate several stages of growth; (4) palygorskite and calcite veins, commonly with thin zeolite-rich zones, cut across and re-open the earlier veins (Figure $3 b$ ).
The low-temperature zone is distinguished from the seafloor weathering zone by nonpervasive alteration which varies in intensity between, and within, individual lithologic units. Greenish brown pillows and breccias generally lack the pronounced color zonation observed in the seafloor weathering zone. Chilled margins are pale green where pillows are highly altered and are dark green to black where pillows are relatively fresh. Volcanic glass is variably altered to smectite \pm phillipsite \pm analcime and fresh glass is locally preserved. Hyaloclastitic material or breccia fill the pillow interstices.

Most massive flows in this zone are relatively fresh with minor surficial celadonite and/or hematite staining. However, zones of intense alteration locally occur along flow margins and to a lesser extent along joint surfaces. These zones consist of celadonite mixed with smectite, clinoptilolite, mordenite, and calcite and may contain massive jasper nodules. Joint surfaces are lined with mixtures of celadonite and smectite, 
platy brown sepiolite, calcite rhombs, bluish white opal, or pyrite. Hematite locally stains fracture surfaces and penetrates inward along flow margins which have not been "celadonitized."

Discontinuous stringers of smectite and celadonite, with or without zeolite or calcite appear to replace aphanitic or glassy patches within the crystalline portion of some flows whereas in others they fill cracks. Primary igneous textures are typically preserved in this zone. In pillow lavas the mesostasis is partly replaced by smectite whereas in massive flow units both smectite and celadonite are present. Alteration within
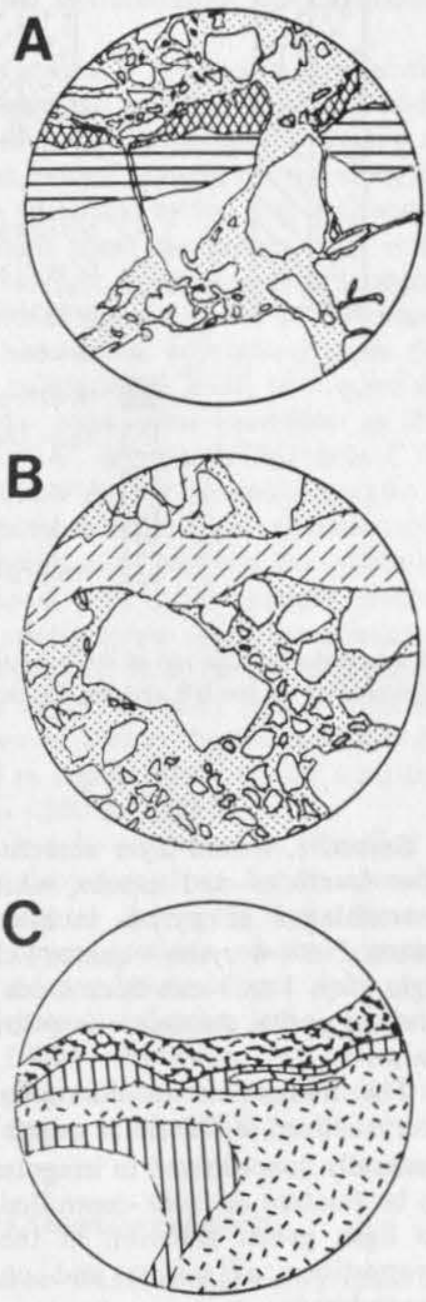

segregation vesicles is similar to that in the seafloor weathering zone. Miarolitic voids, most common in thick massive flows, are partly to completely filled with clay minerals.

The diversity and discontinuous nature of the vein systems reflect the heterogeneous style of alteration in the lowtemperature zone. Despite this heterogeneity, some generalizations may be made: (1) in all cooling-units, smectite $\pm \mathrm{Fe}$ hydroxides is the first phase to form, lining cracks, fractures, vesicles, and vugs (Figure $3 d$ ); (2) assemblages of analcime, phillipsite, gmelinite, natrolite, and chabazite fill
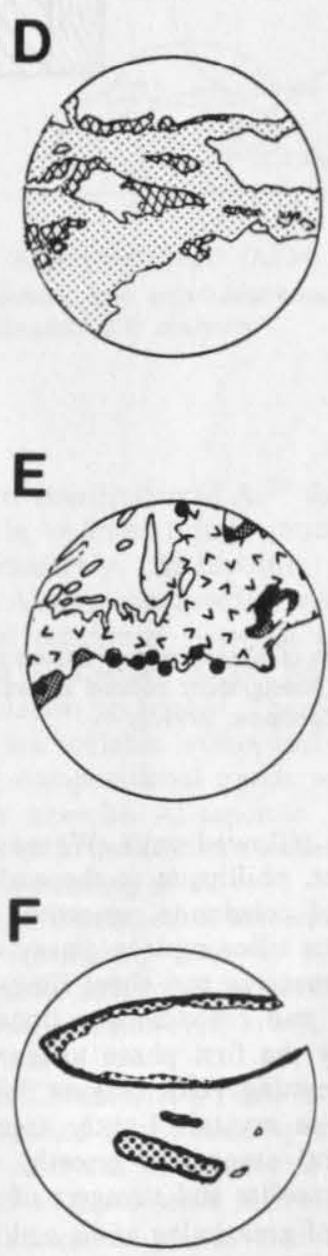

$\overline{2 \mathrm{CM}}$

$\begin{array}{lll}\text { CALC. } & \square \text { CELAD.+SMEC. } & \square \text { QTZ. } \\ \text { SMEC. } & \square \text { LAUM } & \text { EPI. } \\ \text { 目 FE HYDRO. } & \square \text { PYR. } & \square \text { WHOLE ROCK } \\ \square \text { PALY.+CALC. } & \square \text { SMEC./CHL. } \\ & \square \text { CELAD.+SMEC.+CLINO. }\end{array}$

Fig. 3. Sketches of samples showing precipitation sequences in each of the alteration zones. (a) Seafloor weathering zone. Calcite stringers with inclusions of basalt fragments cross-cut a chilled pillow margin. An oxidized halo rims the outer margin of the sample (sample CY1:25.95 m), (b) Seafloor weathering zone. Late-stage palygorskite + calcite vein cross-cuts a heterolitic breccia in a calcite matrix (sample CY1:58.50 m), (c) Low-temperature zone. Upper flow margin altered to celadonite + smectite + clinoptilolite. Glassy margin is partially palagonitized (sample CY1A:45.80 m), (d) Lowtemperature zone. Calcite, with minor analcime, fills re-opened smectite-filled fracture (sample CY1:256.20 m), (e) Transition zone. Laumontite filled vug is lined with mixed-layer smectite/chlorite and pyrite (CY1A:300.45 m), $(f)$ Upper dyke zone. Chlorite-lined vug is coated with quartz and partially filled with epidote (CY1A:432.72 m). Glassy marg., glassy margin; whole rock, variably altered whole rock; other abbreviations are given in Table 1 . 


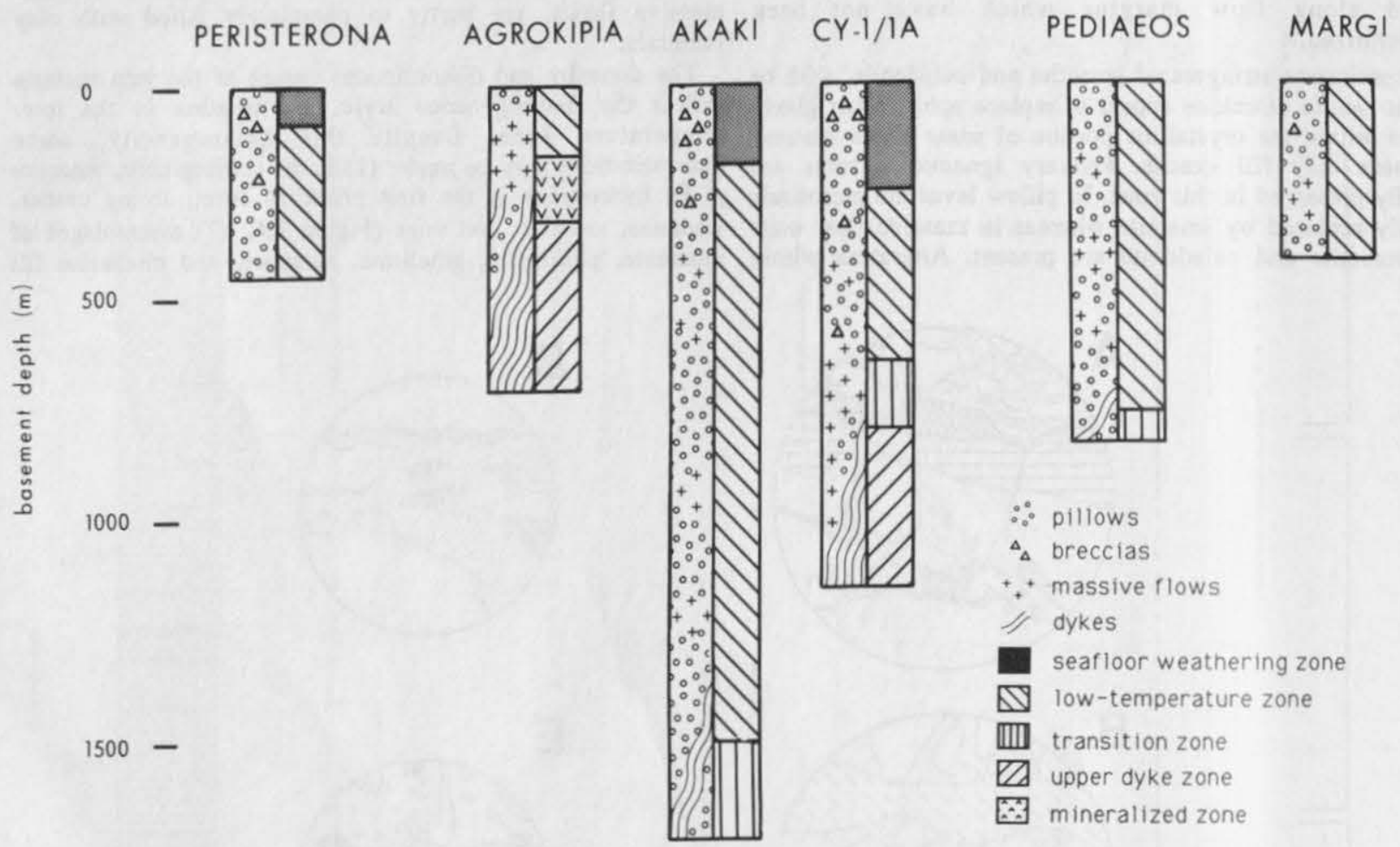

Fig. 4. Distribution of alteration zones along the northern flank of the ophiolite. The top of the extrusive sequence was used as the datum. The stratigraphic column shows the distribution of lithologies on the left and the alteration zones on the right [from Gillis and Robinson, 1991b].

vesicles and fractures in pillowed units. Where analcime and phillipsite occur together, phillipsite is the earliest phase to form; (3) assemblages of celadonite, smectite, clinoptilolite, mordenite, and amorphous silica replace glassy zones and fill fractures and cracks in massive and sheet flows (Figure $3 c$ ). Where clinoptilolite and mordenite occur together, clinoptilolite is generally the first phase to form; (4) calcite fills re-opened or cross-cutting veins (Figure $3 d$ ). Successive layers of euhedral calcite crystals lightly mantled by clay minerals indicate several stages of growth; (5) veins of palygorskite + calcite \pm zeolite and stringers of gypsum were deposited in the centers of preexisting veins and fill clay-lined fractures. Gypsum is generally restricted to the low-temperature zone.

The transition zone has characteristics of both the overlying low-temperature zone and the underlying upper dyke zone. Its upper boundary is marked by the appearance of laumontite and quartz; its lower boundary is marked by the dominance of chlorite + quartz + pyrite assemblages in the groundmass and the appearance of epidote.

Margins of pillows and massive flows and glassy brecciated zones are variably altered to smectite, mixed-layer smectite/chlorite, laumontite, and quartz. Clinoptilolite, mordenite, and celadonite \pm smectite locally replace glassy zones in the upper few tens of meters.

Ovoid, clay-lined vugs are either open or partially to totally filled with assemblages of quartz, laumontite, calcite, pyrite, and clay minerals (Figure $3 e$ ). Prismatic quartz radiates inward from the vug walls; laumontite fills the interstices. Where present, calcite is the latest phase to form and locally appears to replace laumontite. Vesicles are locally filled with mixtures of gmelinite, chabazite, and calcite.
Smectite, mixed-layer smectite/chlorite, or rarely chlorite, line fractures and cracks which are variably filled with assemblages of pyrite, laumontite, calcite, analcime, and quartz. Narrow pyrite + quartz + chlorite stringers are rimmed by light grey, 1 to 3 -mm-thick halos rich in quartz and very finedgrained pyrite. Analcime is restricted to the upper half of the zone.

The mesostasis in the upper dyke zone is completely recrystallized to chlorite + quartz \pm pyrite \pm epidote. Epidote is generally concentrated in irregular patches which do not appear to be fracture or crack-controlled. Distinctive, irregular, purple to light green zonation in the rocks reflects the relative proportions of quartz and chlorite, respectively, in the groundmass.

Flow and dyke margins are completely altered to assemblages of chlorite, quartz and epidote; no fresh glass is preserved. Brecciated textures in flow tops are generally preserved although the fragments are completely recrystallized. Discontinuous, jasper-rich zones overprint zones altered to assemblages of quartz + chlorite + epidote.

Epidosites composed dominantly of epidote with minor quartz, chlorite, magnetite, and jasper are erratically distributed. These irregular zones range from $\mathrm{cms}$ to tens of $\mathrm{cms}$ in size and appear to replace glassy margins.

Igneous textures are generally preserved except in areas of most intense alteration, such as the epidosites. Textures in segregation vesicles are obscured because the groundmass is completely altered to very fine-grained epidote, quartz, and chlorite. Chlorite-lined vesicles and vugs are rimmed with quartz and filled with assemblages of epidote, pyrite, calcite, chlorite, and prehnite (Figure $3 f$ ).

Veins are much less abundant than in the overlying zones. 
Fractures and cracks are lined with mixtures of chlorite, epidote, albite, quartz, and pyrite and are locally coated with Fe-stained calcite. Narrow pyrite and quartz stringers are rimmed by light green, chlorite-rich halos whereas randomly distributed veins of pyrite, $10-15 \mathrm{~mm}$ wide, lack halos. In field exposures, laumontite commonly overprints epidote in the upper dyke zone.

Mineralized zones, which include massive sulfide deposits, mineralized stockwork zones, and smaller zones of mineralization, are located at all stratigraphic levels in the extrusive sequence and sheeted dyke complex [Constantinou, 1980]. These represent subvertical zones of intense, high temperature alteration and their characteristics are summarized in Table 1.

Distribution of alteration zones. The various alteration zones have a consistent vertical pattern in the Troodos ophiolite although they are laterally discontinuous (Figure 4). The seafloor weathering zone, where present, occurs along the lava/sediment boundary. It is underlain by the low-temperature zone followed by the transition zone; the lowest zone is the upper dyke zone. Where the seafloor weathering zone is absent, the low-temperature zone extends upward to the lava/sediment boundary. The mineralized zone forms subvertical pipes that crosscut all but the highest stratigraphic level; it is generally underlain by the upper dyke zone. One exception to this stratigraphy is the Agrokipia "A" deposit (CCSG hole CY2) where the low-temperature zone underlies the outer margins of the mineralized zone because of the shape of the alteration pipe [Sunkel et al., 1987]. The boundaries between the alteration zones are generally gradational over a few meters. Lateral variations in thickness and stratigraphic depth are illustrated by the low-temperature zone (Figure 4 ). It ranges in thickness from 150 to $1200 \mathrm{~m}$ and its upper boundary ranges from the sediment/lava boundary down to $300-\mathrm{m}$ depth and its lower boundary from 150 to $>1400 \mathrm{~m}$ depth. Similarly, the transition zone ranges in thickness from $<200$ to $>500 \mathrm{~m}$.

The lower boundary of upper dyke zone was not identified in our field area. Studies of the subjacent sheeted dyke complex show that alteration equivalent to the upper dyke zone is generally restricted to the upper portions of the complex [Baragar et al., 1987]; at deeper levels, upper dyke zone assemblages are restricted to rocks surrounding large epidosites bodies [Richardson et al., 1987]. Elsewhere, the dykes are typically altered to calcic plagioclase and amphibole with minor chlorite and epidote [Baragar et al., 1987].

\section{Composition and Occurence of Secondary Minerals}

Smectite. Smectite is the most abundant secondary mineral, being characteristic of three of the five alteration zones. Both saponite and $\mathrm{Al}$-saponite have been distinguished on the basis of calculated structural formulas.

Saponite is generally orange-brown to brown with first- to second-order birefringence. Groundmass varieties are finely crystalline, fibrous, radiating, or globular. Saponite that fills voids is usually fibrous to platy and radiates out from the wall of the cavity. A plot of the molar proportions of $\mathrm{Al}_{2} \mathrm{O}_{3}-\mathrm{FeO}$ $\mathrm{MgO}$ shows that the saponites are generally $\mathrm{Mg}$-rich with low $\mathrm{Al}_{2} \mathrm{O}_{3}$ contents (Figure 5). Within individual samples, $\mathrm{FeO} /(\mathrm{FeO}+\mathrm{MgO})$ ratios range from 0.2 to 0.8 . The $\mathrm{MnO}$ content of saponite is generally $<0.5 \mathrm{wt} \%$ (Table 2).

Al-saponite is pale yellow to pale brown with 1st order birefringence and has the same range in habit as saponite. The octahedral occupancy of Al-saponites ranges from 4.4 to 5.3 (Table 2) indicating either that its structure is intermediate or that it is a mixture of dioctahedral and trioctahedral smectite [Alt and Honnorez, 1984]. Al-saponites are more aluminous and slightly more Fe-rich than saponite (Table 2; Figure 5),

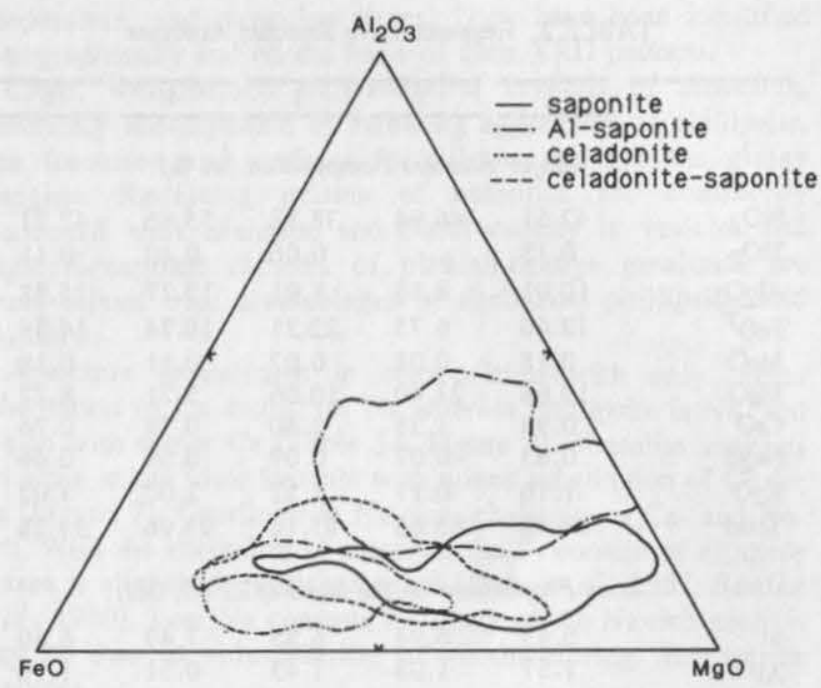

Fig. 5. Molar $\mathrm{Al}_{2} \mathrm{O}_{3}-\mathrm{FeO}-\mathrm{MgO}$ (AFM) proportions of saponite, $\mathrm{Al}-$ saponite, celadonite, and celadonite-saponite in holes CY1/1 A. Fields include approximately 200 analyses.

suggesting that substitution of $\mathrm{Al}^{3+}$ for $\mathrm{Mg}^{2+}$ in the octahedral site resulted in an intermediate structure [Alt and Honnorez, 1984]. Alternatively, Al-saponite may be a mixture of beidellite, an Al-rich, dioctahedral smectite, with saponite. The compositional continuity between saponite and Al-saponite (Figure 5) and the absence of pure beidellite, however, make the former explanation preferable. The $\mathrm{FeO} /(\mathrm{FeO}+\mathrm{MgO})$ ratios of Al-saponites are variable within individual samples; there are no consistent compositional trends with depth. MnO contents are similar to saponite. Al-saponite is generally restricted to the upper $500 \mathrm{~m}$ of the studied sections and is most abundant in the seafloor weathering zone.

Nontronite, a dioctahedral smectite, has been identified in the seafloor weathering zone by $\mathrm{X}$ ray analyses [Elsbree, 1985]. Calculated structural formulas from this study did not confirm its presence; however, low-K dioctahedral clays may in fact be nontronite.

Celadonite. Celadonite, a ferric iron-rich dioctahedral mica, is readily identified in the field by its distinctive bluish-green color. X ray analyses of celadonite generally reveal distinct celadonite and smectite peaks indicating that most samples are physical mixtures of these two minerals. Furthermore, octahedral totals which range from 4.0 to 5.6 indicate that they are generally not true dioctahedral clays (Table 3 ). Interlayering of celadonite with trioctahedral saponite would result in an octahedral total intermediate between dioctahedral and trioctahedral. Further support for this interpretation is the systematic decrease in $\mathrm{K}_{2} \mathrm{O}$ content with increasing octahedral totals and thus saponite component [Gillis, 1987]. An increase in $\mathrm{FeO}$ and $\mathrm{K}_{2} \mathrm{O}$ and a decrease in $\mathrm{Al}_{2} \mathrm{O}_{3}$ contents characterize the transition from pure saponite through celadonite-saponite to celadonite. High octahedral totals reported for celadonites from DSDP leg 37 were also attributed to saponite interlayering [Andrews, 1980]. Excess $\mathrm{Si}$ in the tetrahedral site of a few celadonite samples may be attributed to the close association of celadonite with amorphous or cryptocrystalline silica. Petrographically identified celadonite has therefore been subdivided into two clay types: celadonite and celadonitesaponite, the latter being a physical and/or structural mixture of saponite and celadonite. This should not be considered a strict subdivision, however, as the compositions and structures are continuous between the two endmember components. 
TABLE 2. Representative Smectite Analyses

\begin{tabular}{|c|c|c|c|c|c|}
\hline & 1 & 2 & 3 & 4 & 5 \\
\hline \multicolumn{6}{|c|}{ Major Element Composition (wt \%) } \\
\hline $\mathrm{SiO}_{2}$ & 42.51 & 46.94 & 38.32 & 55.86 & 47.71 \\
\hline $\mathrm{TiO}_{2}$ & 0.13 & - & 0.06 & 0.40 & 0.11 \\
\hline $\mathrm{Al}_{2} \mathrm{O}_{3}$ & 10.01 & 8.86 & 7.91 & 17.77 & 15.88 \\
\hline $\mathrm{FeO}^{T}$ & 12.60 & 6.75 & 22.21 & 10.74 & 14.39 \\
\hline $\mathrm{MnO}$ & 0.18 & 0.08 & 0.02 & 0.11 & 0.18 \\
\hline $\mathrm{MgO}$ & 19.68 & 21.40 & 10.56 & 5.71 & 8.77 \\
\hline $\mathrm{CaO}$ & 0.98 & 1.38 & 2.40 & 0.78 & 0.76 \\
\hline $\mathrm{Na}_{2} \mathrm{O}$ & 0.63 & 0.07 & 0.09 & 0.59 & 0.46 \\
\hline $\mathrm{K}_{2} \mathrm{O}$ & 1.16 & 0.17 & 1.57 & 2.00 & 3.02 \\
\hline Total & 87.88 & 85.65 & 83.14 & 93.96 & 91.28 \\
\hline \multicolumn{6}{|c|}{ Cation Proportions on the Basis of $22(\mathrm{O}, \mathrm{OH})$} \\
\hline $\begin{array}{l}\mathrm{Si} \\
\mathrm{Al}^{\mathrm{iv}}\end{array}$ & $\begin{array}{l}6.43 \\
1.57\end{array}$ & $\begin{array}{l}6.94 \\
1.08\end{array}$ & $\begin{array}{l}6.55 \\
1.45\end{array}$ & $\begin{array}{l}7.49 \\
0.51\end{array}$ & $\begin{array}{l}6.90 \\
1.10\end{array}$ \\
\hline Total & 8.00 & 8.00 & 8.00 & 8.00 & 8.00 \\
\hline $\mathrm{Al}^{\mathrm{vi}}$ & 0.22 & 0.48 & 0.14 & 2.30 & 1.61 \\
\hline $\mathrm{Fe}$ & 1.60 & 0.83 & 3.17 & 1.20 & 1.74 \\
\hline Mn & 0.02 & 0.01 & - & 0.01 & 0.02 \\
\hline $\mathrm{Mg}$ & 4.44 & 4.72 & 2.69 & 1.14 & 1.89 \\
\hline Ti & - & - & 0.01 & - & 0.01 \\
\hline Total & 6.28 & 6.04 & 6.02 & 4.69 & 5.27 \\
\hline $\mathrm{Ca}$ & 0.16 & 0.22 & 0.44 & 0.11 & 0.12 \\
\hline Na & 0.18 & 0.02 & 0.03 & 0.15 & 0.13 \\
\hline K & 0.22 & 0.03 & 0.34 & 0.34 & 0.56 \\
\hline Total & 0.56 & 0.27 & 0.81 & 0.66 & 0.81 \\
\hline
\end{tabular}

Dash indicates not detected; $\mathrm{FeO}^{T}$, total $\mathrm{Fe}$ as $\mathrm{FeO} ; 1$, orangebrown saponite, groundmass (KG:83:018; Pediaeos section); 2 , orange-brown saponite, vein (KG:82:022; Akaki section); 3, orange-brown, $\mathrm{Fe}$-rich saponite, groundmass (KG:83:176; Pediaeos section); 4, yellowish green Al-saponite, vesicle (CY1:72.75 m); 5, yellowish green Al-saponite, groundmass (CY1:75.25 m).
Chlorite and Mixed-layer Smectite/Chlorite. Trioctahedral chlorite and physical and structural mixtures of smectite and chlorite have been identified by $\mathbf{X}$ ray analyses and calculated structural formulas following the methods of Brindley and Brown [1980]. In thin section, chlorite is generally cryptocrystalline to fibrous and pale green. Most chlorites have anomalous blue interference colors although a few display first-order birefringence. Groundmass-replacing smectite/ chlorite is usually petrographically indistinguishable from coexisting saponite or celadonite-saponite. Void-filling varieties, however, are commonly fibrous to platy and pale green to brownish-green with first- to second-order birefringence.

The proportion of chlorite and smectite in the mixed-layer clays varies from smectite with minor chlorite to chlorite with minor smectile, although mixtures dominated by smectite are most common [Gillis, 1987]. Compositionally, the transition from saponite to chlorite is marked by a decrease in $\mathrm{SiO}_{2}$ and an increase in $\mathrm{Al}_{2} \mathrm{O}_{3}$ [Bettison and Schiffman, 1988]. On the basis of $22(\mathrm{O}, \mathrm{OH})$, the cation proportions of $\mathrm{Si}$ and $\mathrm{Al}$ in saponite range from 6.4 to 7.0 and 1.6 to 1.9 , respectively and in chlorites from 4.4 to 4.9 and 3.2 and 3.4 , respectively. Thus clay minerals with $\mathrm{Si}$ and $\mathrm{Al}$ proportions intermediate between smectite and chlorite are considered mixed-layer smectite/chlorite. This approach, however, does not indicate the abundance of the two end-member clays.

The majority of chlorites are pynochlorites with a narrow range in $\mathrm{Fe} /(\mathrm{Fe}+\mathrm{Mg}$ ) cation ratios (Figure 6; Table 4) [Herzig and Friedrich, 1987; Schiffman and Smith, 1988]; chlorites from individual samples are uniform in composition. Chlorite contains up to 1.5 wt\% MnO [Herzig, 1988; Gillis and Robinson, 1991a], with individual samples varying by up to 1 wt\%. The compositions of void-filling and groundmass replacing phases are indistinguishable. Mixed-layer smectite/chlorite is slightly more $\mathrm{Mg}$-rich than chlorite with $\mathrm{Fe} /(\mathrm{Fe}+\mathrm{Mg}$ ) ratios between 0.2 and 0.4 (Table 4; Figure 6).

Zeolites. Several varieties of zeolites fill voids or, rarely, replace groundmass minerals in the seafloor weathering, low-

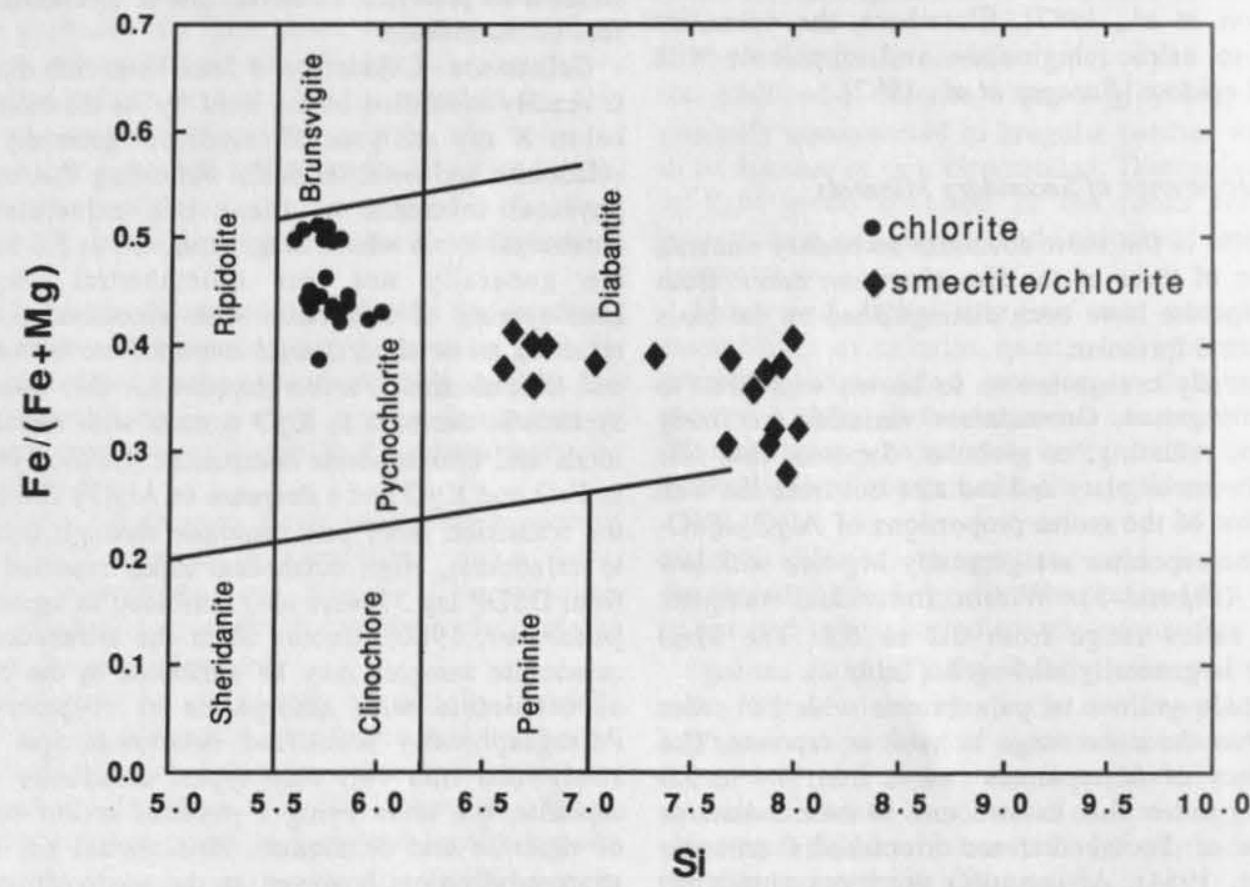

Fig. 6. Compositional classification of chlorite and mixed-layer smectite/chlorite from holes CY1/1A [after Hey, 1954]. Cation proportions of $\mathrm{Si}, \mathrm{Fe}$, and $\mathrm{Mg}$ were calculated on the basis of $28(\mathrm{O}, \mathrm{OH})$. 
TABLE 3. Representative Celadonite Analyses

\begin{tabular}{|c|c|c|c|c|}
\hline & 1 & 2 & 3 & 4 \\
\hline \multicolumn{5}{|c|}{ Major Element Composition (wt\%) } \\
\hline $\mathrm{SiO}_{2}$ & 55.85 & 49.57 & 52.32 & 55.80 \\
\hline $\mathrm{TiO}_{2}$ & 0.16 & 0.23 & 0.11 & - \\
\hline $\mathrm{Al}_{2} \mathrm{O}_{3}$ & 2.32 & 8.14 & 6.16 & 0.77 \\
\hline $\mathrm{Fe}_{2} \mathrm{O}_{3}{ }^{T}$ & 19.69 & 15.16 & 18.70 & 22.24 \\
\hline $\mathrm{MgO}$ & 6.18 & 10.59 & 6.64 & 6.13 \\
\hline $\mathrm{CaO}$ & 0.43 & 0.17 & 0.07 & \\
\hline $\mathrm{Na}_{2} \mathrm{O}$ & 0.10 & 1.35 & 0.13 & 0.04 \\
\hline $\mathrm{K}_{2} \mathrm{O}$ & 9.44 & 2.37 & 8.41 & 8.80 \\
\hline Total & 94.17 & 87.58 & 92.54 & 93.78 \\
\hline \multicolumn{5}{|c|}{ Cation Proportions on the Basis of $22(\mathrm{O}, \mathrm{OH})$} \\
\hline $\mathrm{Si}$ & 7.95 & 7.25 & 7.65 & 8.22 \\
\hline $\mathrm{Al}^{\mathrm{iv}}$ & 0.05 & 0.75 & 0.35 & - \\
\hline Total & 8.00 & 8.00 & 8.00 & 8.22 \\
\hline$A l^{v i}$ & 0.34 & 0.65 & 0.71 & 0.14 \\
\hline $\mathrm{Fe}$ & 2.12 & 1.67 & 2.06 & 1.35 \\
\hline $\mathrm{Mg}$ & 1.33 & 2.30 & 1.45 & 2.47 \\
\hline $\mathrm{Ti}$ & 0.02 & 0.03 & 0.01 & - \\
\hline Total & 3.81 & 4.65 & 4.23 & 3.96 \\
\hline $\mathrm{Ca}$ & - & 0.07 & 0.03 & 0.01 \\
\hline $\mathrm{Na}$ & 0.03 & 0.04 & 0.04 & 0.02 \\
\hline $\mathrm{K}$ & 1.73 & 0.44 & 1.56 & 1.66 \\
\hline Total & 1.76 & 0.55 & 1.63 & 1.69 \\
\hline
\end{tabular}

Dash indicates not detected; $\mathrm{FeO}^{T}$, total $\mathrm{Fe}$ as $\mathrm{Fe}_{2} \mathrm{O}_{3} ; 1$, celadonite, vesicle (CY1A:8.78 m); 2, celadonite-saponite, groundmass (CY1A:49.57m); 3, celadonite-saponite, vein (CY1A:52.32m); 4, celadonite, groundmass (KG:82:165; Akaki section). temperature, and transition zones. They have been identified petrographically and on the basis of their XRD patterns.

Clear, well-formed trapezohedral crystals of analcime, commonly accompanied by radiating aggregates of phillipsite, line fractures and vesicles in pillows and replace glassy margins. Radiating prisms of natrolite are commonly associated with analcime and occur chiefly in vesicles and vugs. Hexagonal clusters of pinkish-orange gmelinite are finely mixed with assemblages of chabazite, phillipsite, and analcime.

Analcime is uniform in composition with only minor substitution of $\mathrm{Ca}$ and $\mathrm{K}$ for $\mathrm{Na}$ whereas phillipsite is $\mathrm{Na}$ - and $\mathrm{K}$-rich with minor $\mathrm{Ca}$ (Table $5 a$; Figure 7). Natrolite analyses are close to the ideal formula with minor substitution of $\mathrm{Ca}$ for $\mathrm{Na}$ (Figure 7). Gmelinite is $\mathrm{Na}$-rich; chabazite is $\mathrm{Ca}$ - and $\mathrm{Na}$ rich. With the exception of natrolite, the Si content of all these phases is slightly higher than usual [Deer et al., 1962; Bohlke et al., 1980]. Low Na contents for many of the Na-rich zeolites may be due to volatilization of alkalis during microprobe analyses.

Yellowish green rosettes of tabular clinoptilolite line the edges of fractures and vesicles in massive and sheet flows and replace hyaloclastite-rich zones. Inclusions of clay minerals are common and partial replacement by calcite is locally evident. Clinoptilolite was distinguished from heulandite by its larger molar $\mathrm{Si} / \mathrm{Al}$ ratio (8.5-10 compared to 6) [Mumpton, $1960]$, higher $(\mathrm{Na}+\mathrm{K}) / \mathrm{Ca}$, and the constancy of the 020 peak upon heating [Boles, 1972] (Table 5b; Figure 7).

Fibrous mordenite is typically associated with clinoptilolite in vesicles and in glassy margins where it is the last of the two phases to form. Higher than normal $\mathrm{Si}$ contents probably reflect intermixing with quartz in the transition zone [Deer et al., 1962]. Samples from hole CY1A are $\mathrm{Na}+\mathrm{K}$-rich, whereas $\mathrm{Ca}$ is the dominant cation in the samples from the Akaki River section (Table $5 b$; Figure 7).

TABLE 4. Representative Chlorite and Mixed-Layer Smectite/Chlorite Analyses

\begin{tabular}{|c|c|c|c|c|c|c|}
\hline & 1 & 2 & 3 & 4 & 5 & 6 \\
\hline \multicolumn{7}{|c|}{ Major Element Composition (wt\%) } \\
\hline $\mathrm{SiO}_{2}$ & 27.37 & 27.05 & 25.97 & 38.11 & 39.19 & 33.98 \\
\hline $\mathrm{Al}_{2} \mathrm{O}$ & 17.87 & 16.64 & 20.31 & 9.47 & 11.77 & 12.50 \\
\hline $\mathrm{FeO}^{T}$ & 25.10 & 30.52 & 24.45 & 17.66 & 19.12 & 8.08 \\
\hline $\begin{array}{l}\mathrm{MnO} \\
\mathrm{MpO}\end{array}$ & 0.86 & 0.42 & 1.10 & 0.24 & 0.28 & 0.23 \\
\hline $\begin{array}{l}\mathrm{MgO} \\
\mathrm{CmO}\end{array}$ & 15.98 & 13.13 & 13.82 & 18.31 & 16.88 & \\
\hline $\begin{array}{l}\mathrm{C} 2 \mathrm{O} \\
\mathrm{Na}_{2} \mathrm{O}\end{array}$ & 0.08 & 0.13 & 0.09 & 1.18 & $\begin{array}{l}0.34 \\
0.68\end{array}$ & $\begin{array}{l}0.32 \\
0.09\end{array}$ \\
\hline $\mathrm{K}_{2} \mathrm{O}$ & $\begin{array}{l}0.18 \\
0.01\end{array}$ & $\overline{0.05}$ & $\begin{array}{l}0.32 \\
-\end{array}$ & $\begin{array}{l}1.08 \\
0.33\end{array}$ & 1.89 & 0.09 \\
\hline Total & 87.45 & 87.94 & 86.06 & 86.14 & 89.87 & 81.30 \\
\hline \multicolumn{7}{|c|}{ Cation Proportions on the Basis of $28(\mathrm{O}, \mathrm{OH})$} \\
\hline $\begin{array}{l}\text { Si } \\
\mathbf{A l}^{\text {iv }}\end{array}$ & $\begin{array}{l}5.80 \\
2.20\end{array}$ & $\begin{array}{l}5.87 \\
2.12\end{array}$ & $\begin{array}{l}5.58 \\
2.42\end{array}$ & $\begin{array}{l}7.75 \\
0.25\end{array}$ & $\begin{array}{l}7.68 \\
0.32\end{array}$ & $\begin{array}{l}6.98 \\
1.02\end{array}$ \\
\hline Total & 8.00 & 8.00 & 8.00 & 8.00 & 8.00 & 8.00 \\
\hline $\mathrm{Al}^{\mathrm{vi}}$ & 2.26 & 2.13 & 2.73 & 0.88 & 1.04 & 0.49 \\
\hline $\mathrm{Fe}$ & 4.45 & 5.53 & 4.40 & 3.00 & 3.13 & 1.38 \\
\hline $\mathrm{Mg}$ & 5.05 & 4.24 & 4.43 & 5.55 & 4.93 & 7.39 \\
\hline Mn & 0.15 & 0.08 & 0.20 & 0.04 & 0.05 & 0.04 \\
\hline a & 0.02 & - & 0.02 & 0.26 & 0.07 & 0.07 \\
\hline $\mathrm{Ne}$ & 0.07 & - & 0.13 & 0.21 & 0.13 & 0.01 \\
\hline $\mathbf{K}$ & - & 0.01 & - & 0.04 & 0.24 & 0.01 \\
\hline Total & 12.00 & 12.01 & 11.91 & 9.10 & 9.59 & 9.39 \\
\hline
\end{tabular}

Dash indicates not detected; $\mathrm{FeO}^{T}$, total $\mathrm{Fe}$ as $\mathrm{FeO} ; 1$, chlorite, groundmass (CY1A:266.60 m); 2, chlorite, groundmass (CY1A:464.00 m); 3, chlorite, groundmass (CY1A:598.15 m); 4, smectite/chlorite, groundmass (CY1A:188.75 m); 5, smectite/chlorite, groundmass (CY1A:250.20); 6, smectite/chlorite, groundmass (CY1A:141.52m) 


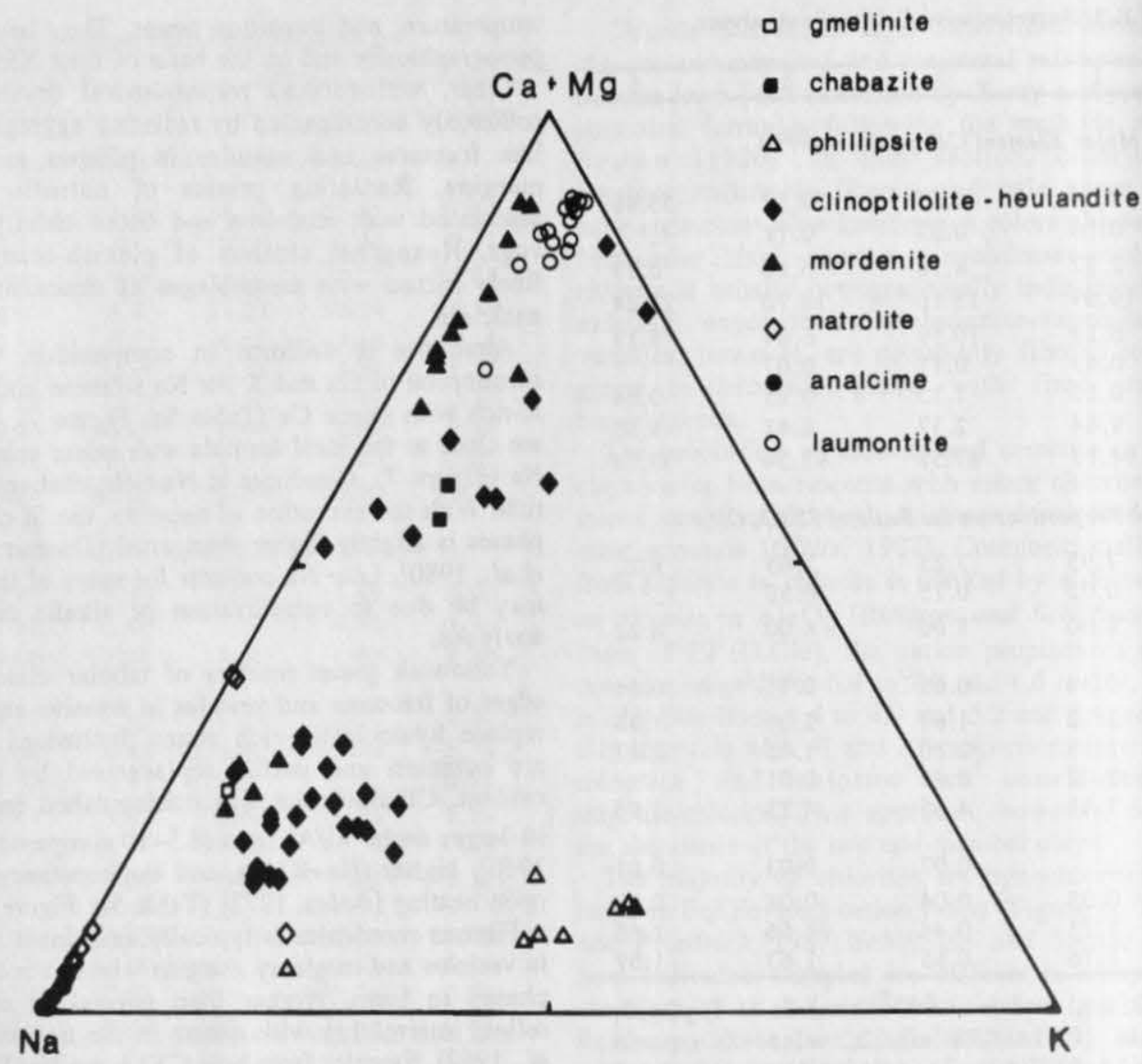

Fig. 7. Molar Na-K-Ca+Mg proportions of zeolites from hole CY1/1A, the Akaki River section, and the Pediaeos River section.

Pinkish white prisms of laumontite, commonly associated with quartz, primarily fill voids and replace glassy margins. XRD analyses indicate that many samples are actually leonhardite, a partially dehydrated variety of laumontite [Coombs, 1952]. Laumontite compositions are close to the ideal formula with minor substitution of $\mathrm{Na}$ and $\mathrm{K}$ for $\mathrm{Ca}$ (Table $5 b$; Figure 7).

Carbonates. Calcite is common throughout the seafloor weathering zone and is locally abundant in the other alteration zones. Generally, the latest phase to be deposited in primary cavities, calcite also forms irregular patches in the groundmass and replaces phenocrysts. Several stages of growth are commonly indicated by successive layers of euhedral calcite crystals, some of which are mantled by clay minerals.

Calcite is generally pure in composition with $<1$ mole \% $\mathrm{MgCO}_{3}$ (Table 6). Manganiferous calcite, containing up to 3.5 wt\% $\mathrm{MnO}$, is present in all alteration zones. Both manganiferous and pure calcites occur within the same veins and vesicles.

Silica. Secondary jasper, chalcedony, opal, and clear colorless quartz form chiefly in the voids of massive flows and dykes. Jasper is commonly associated with celadonite in zones of intense alteration within massive flows. Clear, colorless chalcedony and quartz line or fill vesicles, vugs, and fractures, particularly in the transition zone and upper dyke zone. White to bluish opal-C and opal-CT (classification after Jones and Segnit [1971]) form very thin layers on fractures and coolingjoint surfaces in massive and sheet flows. Quartz is abundant in the groundmass throughout the transition zone and upper dyke zone.

Epidote. Yellowish green, blocky to radiating epidote is a common void-filling phase whereas granular epidote is locally distributed in the groundmass of rocks from the upper dyke zone. It is associated with quartz and chlorite, either mixed or as the latest phase to form. Analyzed epidotes are generally uniform in composition with a narrow range in pistacite component, from 18 to $34\left(\mathrm{Fe} / \mathrm{Fe}+\mathrm{Al}^{\mathrm{iv}}\right.$ ) (Table 7). The pistacite component in the upper dyke zone underlying the mineralized zone of hole CY2A decreases from 36 to 24 with increasing depth over a $300 \mathrm{~m}$ interval [Herzig and Friedrich, 1987]. No compositional change with depth in the upper dyke zone of hole CY1A was noted. Moreover, no compositional differences between groundmass and void-filling phases were noted (Figure 8 ). MnO contents range from 0.03 to $0.70 \mathrm{wt} \%$.

Amphibole. Pale green, prismatic to fibrous actinolite was identified petrographically in the lower $50 \mathrm{~m}$ of hole CY1A. It is commonly intergrown with chlorite in the groundmass and epidote-quartz assemblages in vesicles and vugs.

Prehnite. Tabular grains of prehnite with second order birefringence have been identified in two samples in the upper dyke zone. These grains are associated with quartz in vesicles; a few occurrences in the groundmass were identified petrographically.

$\mathrm{Fe}$-hydroxides. Fe-hydroxides and oxides are present in every alteration zone but are most abundant in the seafloor weathering zone. These phases were identified visually because poor crystallinity prevented XRD identification. Microprobe analyses indicate that they are mixed with clay minerals [Gillis and Robinson, 1991a].

Sulfides and Sulfates. Pyrite is the only secondary sulfide identified outside the mineralized zone. It is most common in the transition zone and upper dyke zone where it is associated 
TABLE 5a. Representative Zeolite Analyses

\begin{tabular}{|c|c|c|c|c|c|c|}
\hline & 1 & 2 & 3 & 4 & 5 & 6 \\
\hline & \multicolumn{6}{|c|}{ Major Element Composition (wt\%) } \\
\hline $\mathrm{SiO}_{2}$ & 59.36 & 55.33 & 47.54 & 57.59 & 50.16 & 53.22 \\
\hline $\mathrm{Al}_{2} \mathrm{O}_{3}$ & 22.61 & 23.24 & 28.77 & 22.24 & 18.64 & 19.39 \\
\hline $\mathrm{FeO}^{T}$ & 0.01 & - & 0.16 & 0.08 & 0.04 & 0.96 \\
\hline $\mathrm{MgO}$ & - & - & - & $\overline{-}$ & 0.06 & 0.05 \\
\hline $\mathrm{CaO}$ & - & - & 0.61 & 0.96 & 3.63 & 4.63 \\
\hline $\mathrm{Na}_{2} \mathrm{O}$ & 12.54 & 11.65 & 9.22 & 2.93 & 11.20 & 2.63 \\
\hline $\mathrm{K}_{2} \mathrm{O}$ & 0.01 & - & - & 4.28 & 1.46 & 1.36 \\
\hline Total & 94.51 & 90.22 & 86.30 & 88.08 & 85.19 & 82.24 \\
\hline \multicolumn{7}{|c|}{ Cation Proportions } \\
\hline Si & 2.43 & 2.38 & 24.43 & 11.43 & 16.15 & 25.53 \\
\hline Al & 1.09 & 1.18 & 17.43 & 5.20 & 7.07 & 10.96 \\
\hline $\mathrm{Fe}$ & - & - & 0.07 & 0.01 & 0.01 & 0.39 \\
\hline $\mathrm{Mg}$ & - & - & - & - & 0.03 & 0.04 \\
\hline $\mathrm{CaO}$ & - & - & 0.34 & 0.20 & 1.25 & 2.38 \\
\hline $\mathrm{Na}$ & 1.00 & 0.97 & 9.19 & 1.13 & 6.99 & 2.45 \\
\hline K & - & - & - & 1.08 & 0.60 & 0.83 \\
\hline $\begin{array}{l}\text { Total } \\
\text { O }\end{array}$ & $\begin{array}{c}4.52 \\
7\end{array}$ & $\begin{array}{c}4.53 \\
7\end{array}$ & $\begin{array}{c}51.46 \\
80\end{array}$ & $\begin{array}{c}19.05 \\
32\end{array}$ & 32.10 & 42.58 \\
\hline & & & & & 48 & \\
\hline
\end{tabular}

Dash indicates not detected; $\mathrm{FeO}^{T}$, total $\mathrm{Fe}$ as $\mathrm{FeO} ; 1$, analcime (KG:82:076); 2, analcime (CY1A:138.0 m); 3, natrolite (KG:83:012); 4, phillipsite (CY1:87.4 m); 5, g melinite (KG:83:204); 6, chabazite (KG:83:204).

TABLE $5 b$. Representative Zeolite Analyses

\begin{tabular}{|c|c|c|c|c|c|c|}
\hline & 1 & 2 & 3 & 4 & 5 & 6 \\
\hline & \multicolumn{6}{|c|}{ Major Element Composition (wt\%) } \\
\hline $\mathrm{SiO}_{2}$ & 63.99 & 66.35 & 69.10 & 66.25 & 56.85 & 54.91 \\
\hline $\mathrm{Al}_{2} \mathrm{O}_{3}$ & 11.26 & 13.59 & 11.99 & 9.36 & 20.19 & 20.51 \\
\hline $\mathrm{FeO}^{T}$ & 0.06 & 0.03 & 0.06 & - & 0.62 & - \\
\hline $\mathrm{MgO}$ & 0.05 & 0.20 & 0.29 & 0.04 & 0.05 & - \\
\hline $\begin{array}{l}\mathrm{CaO} \\
\mathrm{Na}_{2} \mathrm{O}\end{array}$ & $\begin{array}{l}1.96 \\
7.32\end{array}$ & $\begin{array}{l}2.90 \\
3.77\end{array}$ & $\begin{array}{l}3.47 \\
0.93\end{array}$ & $\begin{array}{l}1.62 \\
4.84\end{array}$ & $\begin{array}{l}6.95 \\
1.90\end{array}$ & $\begin{array}{l}7.75 \\
0.34\end{array}$ \\
\hline $\mathrm{K}_{2} \mathrm{O}$ & 0.98 & 1.87 & 0.90 & 0.98 & 1.06 & 0.97 \\
\hline Total & 85.62 & 88.71 & 86.74 & 83.09 & 87.62 & 84.48 \\
\hline
\end{tabular}

Cation Proportions

\begin{tabular}{|c|c|c|c|c|c|c|}
\hline Si & 29.19 & 28.95 & 20.08 & 20.36 & 17.18 & 16.60 \\
\hline Al & 6.05 & 6.99 & 4.11 & 3.39 & 7.19 & 7.54 \\
\hline $\mathrm{Fe}$ & 0.02 & 0.01 & 0.01 & - & 0.16 & - \\
\hline $\mathrm{Mg}$ & 0.03 & 0.13 & - & 0.02 & - & - \\
\hline $\mathrm{Ca}$ & 0.96 & 1.36 & 1.08 & 0.53 & 1.93 & 2.59 \\
\hline $\mathbf{N}$ & 6.47 & 3.19 & 0.52 & 2.88 & 1.11 & 0.21 \\
\hline K & 0.57 & 1.04 & 0.33 & 0.38 & 0.41 & 0.39 \\
\hline Total & 43.29 & 41.67 & 26.13 & 27.54 & 28.00 & 27.33 \\
\hline 0 & 72 & 72 & 48 & 48 & 48 & 48 \\
\hline
\end{tabular}

Dash indicates not detected; $\mathrm{FeO}^{T}$, total $\mathrm{Fe}$ as $\mathrm{FeO} ; 1$, clinoptilolite (KG:82:156); 2, clinoptilolite (KG: 83:085); 3, mordenite (KG:83:166); 4, mordenite (CY1A:43.45 m); 5, laumontite (CY1A:241.4 m); 6, laumontite (CY1A:266.6 m).

with quartz, chlorite, and epidote in the groundmass and with quartz, albite, and chlorite or smectite/chlorite on fracture surfaces. Pyrite is the predominant sulfide within the mineralized zone but lesser amounts of sphalerite, chalcopyrite, and pyrrohotite are also present [Constantinou,
TABLE 6. Representative Calcite Analyses

\begin{tabular}{|c|c|c|c|c|c|c|}
\hline & 1 & 2 & 3 & 4 & 5 & 6 \\
\hline $\mathrm{FeO}^{T}$ & - & - & - & - & 0.06 & $\overline{0.11}$ \\
\hline $\mathrm{MnO}$ & 0.02 & 1.23 & 0.07 & 0.01 & 0.04 & 0.23 \\
\hline $\mathrm{MgO}$ & 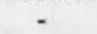 & 0.23 & 0.57 & 0.79 & 0.88 & 0.84 \\
\hline $\mathrm{CaO}$ & 64.79 & 62.90 & 57.39 & 61.20 & 61.39 & 65.07 \\
\hline Total & 64.86 & 62.90 & 58.32 & 62.09 & 61.39 & 66.24 \\
\hline
\end{tabular}

Dash indicates not detected; $\mathrm{FeO}^{T}$, total $\mathrm{i}$ ron as $\mathrm{FeO} ; 1$ and 2 , CY1 A: 145.30 m; 3, CY1:72.75 m; 4, CY1:104.70 m; 5, CY1:197.80 m; 6, CY1:256.21 m.

1980; Adamides, 1987; Lydon, 1984; Herzig and Friedrich, 1987; Richards et al., 1989].

Gypsum is the only sulfate identified outside the mineralized zone. In field exposures, it is primarily associated with gossans. In the low-temperature zone of hole CY1 and the upper dyke zone of hole CY2A it forms clear, massive crystals in late-stage veins [Herzig and Friedrich, 1987; Gillis and Robinson, 1991a].

\section{Alteration of Primary Minerals}

Olivine is partly to totally replaced by an assemblage of clay minerals, calcite, and goethite except in picritic flows where it is replaced by serpentine. The clay minerals present in the alteration assemblage are compositionally similar to coexisting groundmass clays. Clinopyroxene remains essentially fresh in all alteration zones. Celadonite or saponite locally line fractures and coat grain boundaries. Fibrous actinolite occasionally rims clinopyroxene in the upper dyke zone.

In the seafloor weathering, low-temperature, and transition zones, plagioclase may be partly altered to calcite and clay minerals, or totally replaced by adularia, however, there is no

TABLE 7. Representative Epidote Analyses

\begin{tabular}{|c|c|c|c|}
\hline & 1 & 2 & 3 \\
\hline \multicolumn{4}{|c|}{ Major Element Composition (wt\%) } \\
\hline $\mathrm{SiO}_{2}$ & 37.81 & 38.08 & 38.79 \\
\hline $\mathrm{Al}_{2} \mathrm{O}_{3}$ & 25.17 & 24.38 & 22.91 \\
\hline $\mathrm{Fe}_{2} \mathrm{O}_{3} T$ & 8.87 & 9.43 & 10.71 \\
\hline $\mathrm{MnO}$ & 0.17 & 0.18 & 0.20 \\
\hline $\mathrm{MgO}$ & - & - & 0.05 \\
\hline $\mathrm{C} 2 \mathrm{O}$ & 24.46 & 24.05 & 23.34 \\
\hline Total & 96.48 & 96.12 & 96.00 \\
\hline
\end{tabular}

Cation Proportions on the Basis of 12.50

\begin{tabular}{llll}
$\mathrm{Si}$ & 3.07 & 3.11 & 3.18 \\
$\mathrm{Al}^{\mathrm{iv}}$ & $\overline{3}$ & - & - \\
$\mathrm{Total}^{2}$ & 3.07 & 3.11 & 3.18 \\
& & & \\
$\mathrm{Al}^{\mathrm{vi}}$ & 2.41 & 2.34 & 2.22 \\
$\mathrm{Fe}$ & 0.60 & 0.64 & 0.73 \\
Total & 3.01 & 2.99 & 2.95 \\
$\mathrm{Mn}$ & 0.01 & 0.01 & 0.01 \\
$\mathrm{Ca}$ & 2.14 & 2.10 & 2.05 \\
Total & 2.15 & 2.11 & 2.06 \\
$\mathrm{Fe} /\left(\mathrm{Fe}+\mathrm{Al}^{\mathrm{iv}}\right)$ & 0.20 & 0.22 & 0.25 \\
\hline
\end{tabular}

Dash indicates not detected; $\mathrm{FeO}^{T}$, total iron as $\mathrm{Fe}_{2} \mathrm{O}_{3} ; 1$, CY1A:632.25 m, vesicle; 2, CY1A:632.25 m, groundmass; 3, CY1A:339.26 m, vesicle. 


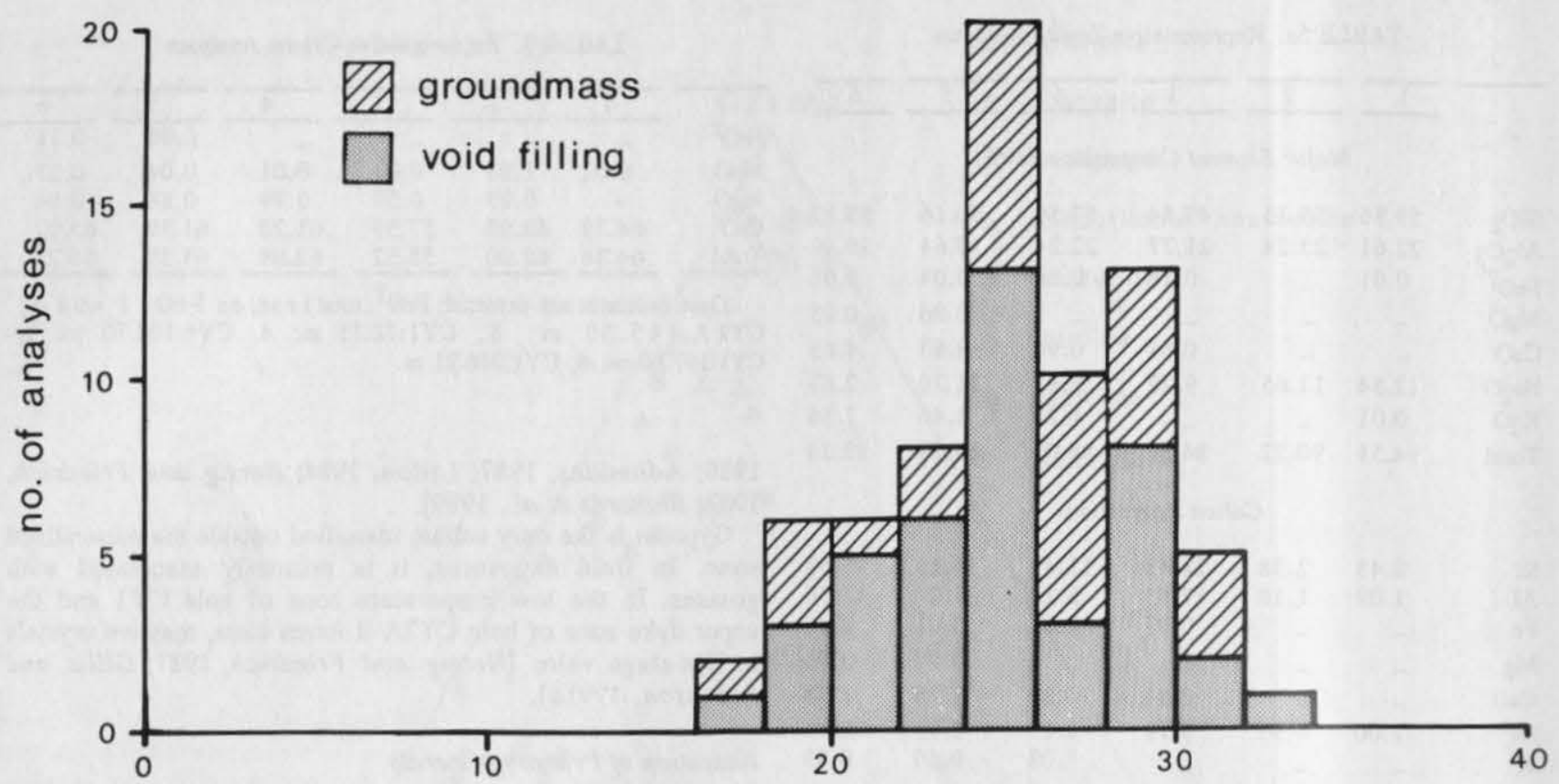

$\mathrm{Fe} / \mathrm{Fe}+\mathrm{Al}^{\mathrm{vi}}$

Fig. 8. Pistacite component ( $\mathrm{Fe} /\left(\mathrm{Fe}+\mathrm{Al}^{\mathrm{iv}}\right)$ ) of groundmass-replacing and void-filling epidote.

consistent pattern in the distribution of these types of alteration. In the upper dyke zone, plagioclase is completely albitized (Ano-15).

Red staining adjacent to titanomagnetite in the seafloor weathering and low-temperature zones indicates that the opaque minerals have expelled iron and are cation deficient [Hall et al., 1987]. Sphene locally rims titanomagnetite in the upper dyke zone.

\section{Oxygen Isotopic Compositions of Secondary Minerals}

Studies of many natural hydrothermal systems indicate that isotopic exchange produces predictable shifts in the $\mathrm{O}$-isotopic composition of both fluids and rocks that reflect temperature, water/rock ratios, and the pattern of fluid flow [e.g., Gregory and Taylor, 1981; Bowers and Taylor, 1985]. Depth profiles in ophiolites and drilled oceanic crust show systematic trends of enrichment and depletion relative to fresh rock values (see summary in Muehlenbachs [1986]). In general, at low temperatures, rocks are enriched and solutions are depleted in $\delta^{18} \mathrm{O}$, whereas at high temperatures the opposite trend is observed. If reactions occur in a high water/rock environment, however, the $\delta^{18} \mathrm{O}$ content of a rock may be shifted without significant modification of the fluid.

The oxygen isotopic content of a suite of typical voidfilling phases from each alteration zone were determined to calculate equilibrium temperatures of formation (Tables 8 and 9). Where independent temperatures are available, mineralwater fractionation factors were used to determine the $\delta^{18} \mathrm{O}$ content of the fluid. Smectite separates from the seafloor weathering zone and low-temperature zone of hole CY1 (Table 8 ) and the low-temperature zone of hole CY2A [Rommel and

TABLE 8. $\delta^{18} \mathrm{O}$ Content (per mille) and Calculated Temperatures of Formation of Silicate Phases From Hole CY-1/1A

\begin{tabular}{|c|c|c|c|c|c|c|c|}
\hline & \multirow{3}{*}{ Mineral } & \multirow{3}{*}{$\begin{array}{c}\text { Alteration } \\
\text { Zone } \\
\end{array}$} & \multirow{3}{*}{$\delta^{18} \mathrm{O}_{\text {SMOW }}$} & \multicolumn{3}{|c|}{ Temperature ${ }^{\circ} \mathrm{C}$} & \\
\hline & & & & \multirow[b]{2}{*}{$-3 \%$} & \multirow{2}{*}{$\frac{\delta^{18} \mathrm{O}}{\%}$} & \multirow{2}{*}{$\begin{array}{c}\text { (water) } \\
+1 \% \\
\end{array}$} & \multirow[b]{2}{*}{$+3 \%$} \\
\hline & & & & & & & \\
\hline Sample & $\overline{\text { smectite }}$ & SWZ & +24.5 & 14.4 & 28.8 & & \\
\hline CY1:233.3 m & smectite & SwZ & +18.4 & 45.5 & 59.0 & & \\
\hline CY1:437.9 m & smectite & LTZ & +24.9 & 17.1 & 21.8 & & \\
\hline CY1A:31.4 m & celadonite & LTZ & +21.2 & 35.7 & 41.3 & & \\
\hline KG:83:087 & celadonite & LTZ & +21.4 & 34.6 & 40.0 & & \\
\hline KG:82:107 & analcime & LTZ & +18.2 & & & & \\
\hline KG: $83: 235$ & chalcedony & LTZ & +23.7 & & 59.0 & & \\
\hline KG: $83: 236$ & chalcedony & LTZ & +26.2 & & 45.3 & & \\
\hline KG:83:116 & clinoptilolite & LTZ & +23.4 & & & & \\
\hline CY1A:513.2 m & chlorite & UDZ & +6.3 & & 87.6 & 122 & 168 \\
\hline CY1A:432.7 m & epidote & UDZ & -0.1 & & & & \\
\hline CY1A:447.0 m & epidote & UDZ & +2.8 & & & & \\
\hline
\end{tabular}

Temperatures calculated using the following fractionation factors: smectite and celadonite, Yeh and Savin [1977]; chalcedony, Knauth and Epstein [1976]; chlorite, Wenner and Taylor [1971]. 
TABLE 9. $\delta^{18} \mathrm{O}$ and $\delta^{13} \mathrm{C}$ Contents (per mille) and Calculated Temperatures of Formation for Carbonates

\begin{tabular}{|c|c|c|c|c|}
\hline $\begin{array}{r}\text { Depth, } \\
\text { m }\end{array}$ & Zone & ${ }^{13} \mathrm{CPDB}_{\mathrm{PD}}$ & ${ }^{18} \mathrm{OSMOW}_{\text {SMOW }}$ & $\begin{array}{c}\text { Temperature } \\
{ }^{\circ} \mathrm{C} \\
\end{array}$ \\
\hline \multicolumn{5}{|l|}{$\overline{\text { CY1 }}$} \\
\hline 58.35 & SWZ & +2.3 & +31.5 & 5.3 \\
\hline 86.30 & SWZ & +1.8 & +30.4 & 9.6 \\
\hline 123.30 & SWZ & +2.0 & +31.5 & 5.3 \\
\hline 233.0 & SWZ & +1.7 & +30.6 & 8.9 \\
\hline 291.00 & LTZ & +2.7 & +30.4 & 9.8 \\
\hline 299.00 & LTZ & +2.8 & +30.9 & 7.8 \\
\hline 410.43 & LTZ & +2.4 & +29.5 & 13.6 \\
\hline \multicolumn{5}{|l|}{ CY1A } \\
\hline 36.35 & LTZ & +1.2 & +26.3 & 27.8 \\
\hline 138.75 & LTZ & +0.8 & +24.8 & 35.6 \\
\hline 242.09 & Z & -0.9 & +22.8 & 46.9 \\
\hline 300.45 & $\boldsymbol{Z}$ & +0.9 & +20.5 & 61.2 \\
\hline 314.05 & Z & +1.7 & +18.4 & 76.6 \\
\hline 390.00 & UDZ & +1.4 & +19.9 & 65.5 \\
\hline 406.00 & UDE & +2.7 & +17.8 & 80.6 \\
\hline 434.00 & UDZ & +0.9 & +20.2 & 63.2 \\
\hline 518.00 & UDZ & +3.0 & +18.4 & 76.3 \\
\hline 617.00 & UDZ & +3.3 & +17.8 & 80.8 \\
\hline
\end{tabular}

Friedrichsen, 1987] have $\delta^{18} \mathrm{O}$ values between +17.2 and $+24.9 \%$ oo. Assuming precipitation from isotopically unmodified Cretaceous seawater $(-1 \%$ [Savin, 1977]), these $d$ ${ }^{18} \mathrm{O}$ values yield temperatures of $22-66^{\circ} \mathrm{C}$. Precipitation from isotopically lighter fluids implies lower temperatures; however, fluids lower than $-4 \%$ would yield temperatures lower than Cretaceous seawater $\left(5-15^{\circ} \mathrm{C}\right.$ [Brass et al., 1982]). Smectites from DSDP hole 504B have lower $\delta^{18} \mathrm{O}$ values $(+11.2$ to $+13.4 \%$ ), implying precipitation at slightly higher temperatures or from a modified fluid whose $\delta^{18} \mathrm{O}$ content was lower than seawater [Alt et al., 1986b].

The $\delta^{18} \mathrm{O}$ content of two celadonite separates from the lowtemperature zone are +21.4 and $+21.2 \%$ (Table 8 ). Calculated temperatures, assuming precipitation from Cretaceous seawater, are $26^{\circ}-27^{\circ} \mathrm{C}$ using the illite-water fractionation factor and $40^{\circ}-41^{\circ} \mathrm{C}$ using the smectite fractionation factor. If these minerals precipitated from isotopically evolved fluids, temperatures would be lower. These temperatures are comparable to those calculated for clay minerals from zones of equivalent alteration in DSDP holes 396,417 , and 418 [Staudigel et al., 1981; Bohlke et al., 1984].

Two chalcedony samples from the low-temperature zone yield temperatures of $45^{\circ}$ and $59^{\circ} \mathrm{C}$ (Table 8). These temperatures are higher than temperatures reported for chalcedony from our field area $\left(28-32^{\circ} \mathrm{C}\right.$ [Heaton and Sheppard, 1977]) and from DSDP Site $417\left(35.4^{\circ} \mathrm{C}\right.$ [Bohlke et al., 1984]).

One analcime sample from the low-temperature zone has a $\delta^{18} \mathrm{O}$ content of $+18.2 \%$, similar to analcimes from DSDP hole 504B $(+17.8$ to $+18.2 \%$ o [Alt et al., 1986b]). Temperature-dependent fractionation factors for analcime-water have not been determined; however, fluid inclusion data for hole 504B analcimes indicate precipitation at approximately $50^{\circ} \mathrm{C}$ [Belyie et al., 1983]. Analcimes from Sites 417 and 418 , interpreted to have formed at temperatures $<50^{\circ} \mathrm{C}$, range from +23.8 to $+24.1 \%$ [Staudigel et al., 1981]. The $\delta^{18} \mathrm{O}$ content of a clinoptilolite separate from the low-temperature zone $(+23.4 \%)$ falls within the range of d-values for zeolites from various DSDP sites where alteration temperatures $\leq 50^{\circ} \mathrm{C}$ have been estimated [Staudigel et al., 1981; Bohlke et al., 1984] .
Epidote-quartz pairs from the upper dyke zone of hole CY2A [Rommel and Friedrichsen, 1987] and the sheeted dyke complex [Heaton and Sheppard, 1977] yield temperatures of $238-305^{\circ} \mathrm{C}$, following the method of Matthews and Schliestedt [1984] which accounts for the fractionation effect of $\mathrm{Fe}$ substitution for $\mathrm{Al}$ in epidote. Fluid-inclusion data for quartz from epidosites within the sheeted dykes yield temperatures of homogenization between $200^{\circ}$ and $410^{\circ} \mathrm{C}$ with a mean trapping temperature of ca. $340^{\circ} \mathrm{C}$ and a maximum value of $440^{\circ} \mathrm{C}$ [Richardson et al., 1987; Schiffman et al., 1987; Cowan and Cann, 1988]. Using these calculated temperatures and the $\delta^{18} \mathrm{O}$ content of co-existing quartz, the quartz-water fractionation equation of Matsuhisa et al. [1979] indicates that epidote and quartz precipitated from unmodified Cretaceous seawater to isotopically enriched solutions $(-0.6$ to $+3.1 \%)$. The $\delta^{18} \mathrm{O}$ contents of two epidote separates from hole CY1/1A fall within the range of other epidote from the Troodos ophiolite (Table 8); however, in the absence of data for co-existing quartz it is only possible to suggest precipitation from similar solutions at similar temperatures.

The $\delta^{18} \mathrm{O}$ value of a chlorite sample from the upper dyke zone of hole CY1/1A is $+6.3 \%$. If solution compositions similar to those inferred for epidote $(-1$ to $+3.1 \%)$ are assumed, calculated temperatures for the chlorite from CY1/1A range from $88^{\circ}$ to $168^{\circ} \mathrm{C}$ (Table 8 ). In contrast, $\delta^{18} \mathrm{O}$ contents of chlorite from the upper dyke zone of hole CY2A [Rommel and Friedrichsen, 1987] and the sheeted dyke complex [Heaton and Sheppard, 1977] range from -0.3 to $+3.9 \%$, indicating higher temperatures $\left(130-240^{\circ} \mathrm{C}\right)$. If the chlorite from CY $1 / 1 \mathrm{~A}$ precipitated at temperatures similar to the other chlorites, the precipitating solution would have been enriched in $\delta^{18} \mathrm{O}$ by 2 $3 \%$ relative to the solutions that precipitated the other chlorites. Without additional data, however, it is not possible to determine whether the chlorite from CY1/1A precipitated at lower temperatures or from isotopically heavier solutions. Chlorite from DSDP hole 504B shows a similar range range in $\delta^{18} \mathrm{O}$ content $\left(+1.1\right.$ to $+6.0^{\circ} \%$ ) which has also been attributed to variation in temperature and/or fluid composition [Friedrichsen, 1985; Alt et al., 1986b].

TABLE 10. Summary of Bulk Compositional Changes

\begin{tabular}{|c|c|c|c|}
\hline & SWZ & LTZ & $\overline{\mathrm{UDZ}}$ \\
\hline $\mathrm{SiO}_{2}$ & - & - & nc \\
\hline $\mathrm{TiO}_{2}$ & nc & nc & nc \\
\hline $\mathrm{Al}_{2} \mathrm{O}_{3}$ & nc & nc & nc \\
\hline $\mathrm{FeO}$ & nc & nc & nc \\
\hline $\mathrm{MnO}$ & nc & nc & (t) \\
\hline $\mathrm{MgO}$ & + & nc & nc \\
\hline $\mathrm{CmO}$ & \pm & nc & $=$ \\
\hline $\mathrm{Na}_{2} \mathrm{O}$ & $=$ & + & $H$ \\
\hline $\mathrm{K}_{2} \mathrm{O}$ & + & + & $=$ \\
\hline $\mathrm{FeO} /\left(\mathrm{FeO}+\mathrm{Fe}_{2} \mathrm{O}_{3}\right)$ & H & + & nc \\
\hline $\mathrm{CO}_{2}$ & $H$ & + & nc \\
\hline $\mathrm{Sr}$ & H & - & - \\
\hline $\mathbf{R b}$ & $H$ & - & - \\
\hline Ba & $H$ & nc & - \\
\hline $\begin{array}{l}\mathrm{C}_{\mathbf{n}} \\
\mathrm{Z}_{\mathbf{n}}\end{array}$ & $\begin{array}{l}\text { nc } \\
\text { nc }\end{array}$ & $\begin{array}{l}\text { nc } \\
\text { nc }\end{array}$ & $\begin{array}{l}(+) \\
(t)\end{array}$ \\
\hline
\end{tabular}

These are average compositional changes documented for holes CY1/1A (see text); symbols indicate qualitative estimates of the magnitude of enrichment or depletion: nc, no change; ++, very enriched; +, variably enriched; $=$, very depleted; - variably depleted; symbols in parentheses indicate element mobility specific to hole CY1/1A. 
O-isotopic contents of carbonates from all alteration zones range from +31.5 to $+17.8 \%$ (Table 9 [Gillis, 1987]). Calculated temperatures of formation for carbonates from hole CY1/1A increase with depth, with temperatures from $5-14^{\circ} \mathrm{C}$ in the seafloor weathering zone and $63-81^{\circ} \mathrm{C}$ in the upper dyke zone (Table 10). Carbon isotopic contents indicate that the carbonates precipitated from solutions with an inorganic carbon component [Muehlenbachs, 1979].

\section{Chemical Effects of Alteration}

Two geochemical suites are recognized in the lavas along the northern flank of the Troodos ophiolite: an andesite-daciterhyodacite suite of arc tholeiite affinity and a picritic basalt to basaltic andesite suite of depleted arc tholeiite affinity [Robinson et al., 1983; Schmincke et al., 1983; Mehegan and Robinson, 1985; Thy et al., 1985]. The lower "nondepleted" suite is aphyric to plagioclase- and clinopyroxene-phyric; the upper "depleted" suite is aphyric, olivine- and clinopyroxenephyric to picritic [Bailey, 1984; Malpas and Langdon, 1984; Baragar et al., 1987]. Both geochemical suites were recognized in hole CY1/1A on the basis of bulk rock compositions (Figure 9 [Robinson et al., 1983; Mehegan, 1988]). The depleted suite occurs in the upper $490 \mathrm{~m}$ and the nondepleted suite occurs below $675 \mathrm{~m}$. Between 490 and $675 \mathrm{~m}$, the depleted and nondepleted suites are intercalated; below $657 \mathrm{~m}$, nondepleted lavas are intruded by depleted dykes (Figure 9).
Bulk compositional changes in each of the alteration zones have been investigated using samples collected for the CCSG from hole CY1/1A. The sampling strategy of this program was to collect samples from most cooling units to study primary compositional variations. Pillow and flow interiors were preferentially sampled over altered rims except where fresh glassy margins were preserved. Where fresher material was not available, altered material was sampled. A study of pillows from the seafloor weathering zone and low-temperature zone of hole CY1/1A shows that pillow interiors are either unaltered or have the same trends in element mobility as pillow rims but to a lesser degree [Baragar et al., 1991]. Similar trends of element mobility have also been documented for rim-core pairs of pillows altered at low-temperatures [Baragar et al., 1977] and at greenschist facies conditions [Humphris and Thompson, 1978]. Thus qualitative compositional trends are discussed in following section for each alteration zone in hole CY1/1A. In the absence of data for the "most" altered samples, it was not possible to calculate quantitative chemical fluxes.

Variations in the major and trace element composition of crystalline rock samples from holes CY1/1A (Figure 9) reflect the variable primary composition and mineralogy of the lava suites as well as the effect of alteration. The chemical effects of alteration were investigated through comparison of the compositions of samples from holes CY1/1A with indicators of alteration $\left(\mathrm{CO}_{2}, \mathrm{H}_{2} \mathrm{O}, \mathrm{Fe}_{2} \mathrm{O}_{3} /\left(\mathrm{FeO}+\mathrm{Fe}_{2} \mathrm{O}_{3}\right)\right)$ and fractionation trends [Robinson et al., 1983; Rautenschlein et al.,
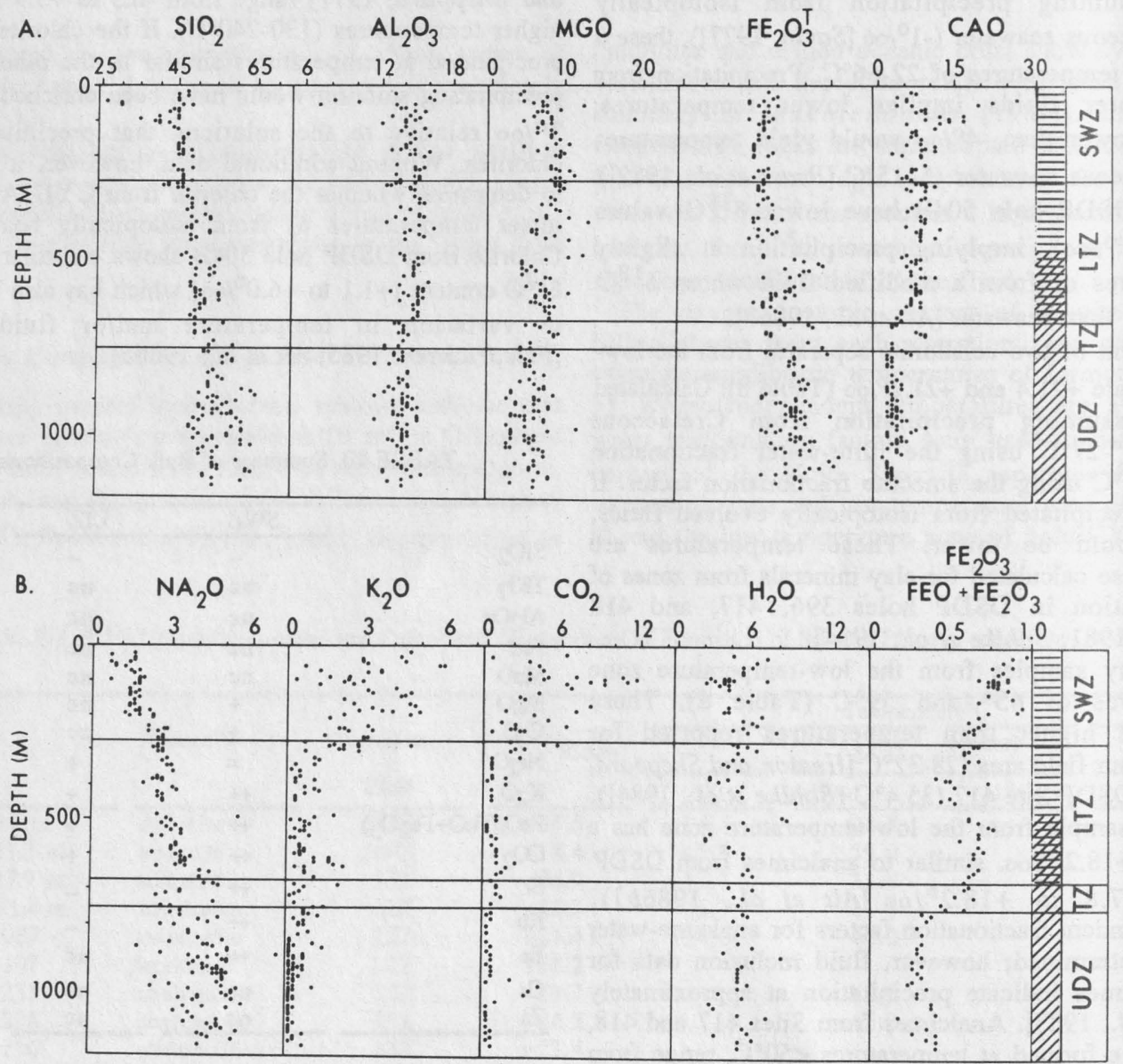

Fig. 9. Major element (wt\%) and trace element (ppm) contents versus depth in the CY1/1A drillcores. Alteration zones are outlined on the right, abbreviations are the same as Table 1; the geochemical suites are outlined on the right: horizontal lines, undepleted suite, diagonal lines, depleted suite. (a) $\mathrm{SiO}_{2}, \mathrm{Al}_{2} \mathrm{O}_{3}, \mathrm{MgO}, \mathrm{Fe}_{2} \mathrm{O}_{3} \mathrm{~T}$, and $\mathrm{CaO}$. (b) $\mathrm{Na}_{2} \mathrm{O}, \mathrm{K}_{2} \mathrm{O}$, $\mathrm{Fe}_{2} \mathrm{O}_{3} /\left(\mathrm{FeO}+\mathrm{Fe}_{2} \mathrm{O}_{3}\right), \mathrm{H}_{2} \mathrm{O}$, and $\mathrm{CO}_{2}$. (c) $\mathrm{TiO}_{2}, \mathrm{Zr}, \mathrm{Y}, \mathrm{Sr}, \mathrm{Rb}$, and $\mathrm{Ba}$. (d) $\mathrm{MnO}, \mathrm{Cu}, \mathrm{Zn}, \mathrm{Cr}$, and $\mathrm{Ni}$. Compositional data are given in Robinson et al., [1991]. 

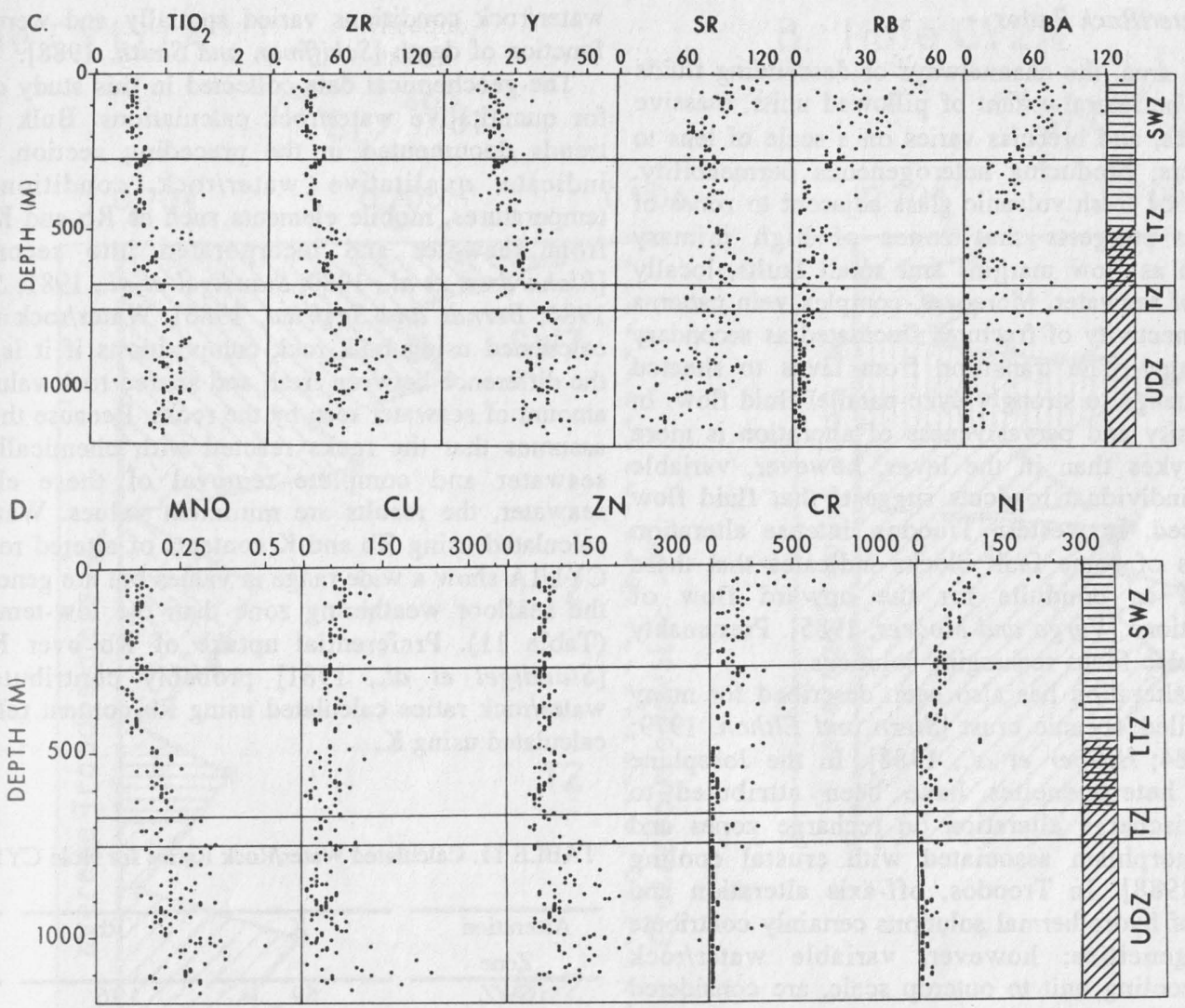

Fig. 9. (continued)

1985; Mehegan, 1988] as well as their variation with depth. Because the degree of alteration is variable within each zone, individual samples vary from fresh rock values to the most enriched or depleted, depending on the element.

The seafloor weathering zone is enriched in $\mathrm{K}_{2} \mathrm{O}, \mathrm{Rb}, \mathrm{Ba}, \mathrm{Sr}$, and $\mathrm{CO}_{2}$ and depleted in $\mathrm{SiO}_{2}$ and $\mathrm{Na}_{2} \mathrm{O}$. $\mathrm{MgO}, \mathrm{Cr}$, and $\mathrm{Ni}$ contents are similar to primary compositions; the range in values, particularly in the upper $75-100 \mathrm{~m}$ where picrites and olivine-phyric lavas are common, primarily reflects variation in the modal abundance of olivine and clinopyroxene (Figures $9 a$ and $9 d)$. Bulk rock $\mathrm{Fe}_{2} \mathrm{O}_{3} /\left(\mathrm{FeO}+\mathrm{Fe}_{2} \mathrm{O}_{3}\right)$ ratios are higher than in the underlying zones (Figure $9 b$ ). Positive correlation between $\left(\mathrm{Fe}_{2} \mathrm{O}_{3} /\left(\mathrm{FeO}+\mathrm{Fe}_{2} \mathrm{O}_{3}\right)\right)$ ratios and $\mathrm{K}_{2} \mathrm{O}, \mathrm{Rb}, \mathrm{Ba}$, and $\mathrm{Sr}$ content indicate that these elements were mobile during an oxidative phase of alteration [Gillis, 1987]. Positive correlation between $\mathrm{CO}_{2}$ and $\mathrm{CaO}$ and negative correlation between $\mathrm{CO}_{2}$ and all other elements suggests that a $\mathrm{CO}_{2}$ metasomatic event contributed to the enrichment of $\mathrm{CaO}$ and the dilution of the other elements. Petrographic relations suggest that the oxidative alteration preceded $\mathrm{CO}_{2}$ metasomatism. Pervasive replacement of plagioclase by $\mathrm{K}$ feldspar was responsible for the enrichment of $\mathrm{K}_{2} \mathrm{O}$ and depletion in $\mathrm{Na}_{2} \mathrm{O}$ and $\mathrm{CaO}$.

The low-temperature zone is also enriched in $\mathrm{K}_{2} \mathrm{O}, \mathrm{Rb}$, and $\mathrm{Ba}$ and depleted in $\mathrm{SiO}_{2}$ and $\mathrm{Sr}$, but to a lesser extent than the seafloor weathering zone. $\left(\mathrm{Fe}_{2} \mathrm{O}_{3} /\left(\mathrm{FeO}+\mathrm{Fe}_{2} \mathrm{O}_{3}\right)\right)$ ratios and $\mathrm{CO}_{2}$ contents are lower than in the seafloor weathering zone (Figure $9 b$ ). Random replacement of plagioclase by $\mathrm{K}$-feldspar and the local abundance of celadonite are responsible for the scatter in $\mathrm{K}_{2} \mathrm{O}$ contents and depletion in $\mathrm{CaO}$. The rocks are enriched in $\mathrm{Na}_{2} \mathrm{O}$ although no $\mathrm{Na}$-bearing, groundmass-replacing secondary phases have been recognized.
$\mathrm{K}_{2} \mathrm{O}, \mathrm{Rb}$, and $\mathrm{Sr}$ contents are either depleted or show no change in the upper dyke zone. $\mathrm{Ba}$ is generally depleted except for a few samples in the upper half of the zone. Variable $\mathrm{TiO}_{2}$, $\mathrm{MgO}, \mathrm{Cr}, \mathrm{Ni}, \mathrm{Zr}$, and $\mathrm{Y}$ contents in this zone (Figures $9 c$ and $9 d)$ are considered to be primary and reflect the intercalation of dykes of the depleted suite with lavas from the nondepleted suite. Albitization of plagioclase in the transition zone and upper dyke zone resulted in $\mathrm{Na}$-enrichment and $\mathrm{Ca}$-depletion. $\left(\mathrm{Fe}_{2} \mathrm{O}_{3} /\left(\mathrm{FeO}+\mathrm{Fe}_{2} \mathrm{O}_{3}\right)\right)$ ratios and $\mathrm{CO}_{2}$ contents tend to be lower than in the overlying zones. Higher $\mathrm{CO}_{2}$ contents between 940 and $1020 \mathrm{~m}$ depth occur in an interval where narrow shear zones are common.

The upper dyke zone and, to a lesser extent, the transition zone are enriched in $\mathrm{MnO}, \mathrm{Cu}$, and $\mathrm{Zn}$ (Figure 9d). Mn-rich chlorites and mixed-layer smectite/chlorite contributed to the enrichment of Mn. Small zones of metal enrichment and mineralization are distributed throughout the sheeted dyke complex. Outside of these zones, the rocks in the upper dyke zone are slightly depleted in metals relative to fresh rock values [Baragar et al., 1987].

In all alteration zones, $\mathrm{SiO}_{2}, \mathrm{Al}_{2} \mathrm{O}_{3}, \mathrm{Fe}_{2} \mathrm{O}_{3}{ }^{\mathrm{T}}$, and $\mathrm{MgO}$ generally follow the fractionation trends of the geochemical suites (Figure 9 [Gillis, 1987]), implying that these elements were essentially immobile. $\mathrm{TiO}_{2}, \mathrm{Zr}$, and $\mathrm{Y}$ also follow fractionation trends indicating that these elements were also immobile during alteration [Mehegan 1988]. Chemical variation within several cooling units from the seafloor weathering zone and low-temperature zone of hole CY1, however, indicates that $\mathrm{Y}$ may be depleted in the margins of some pillows [Baragar et al., 1991].

Rocks from the transition zone share the geochemical signatures of both the overlying low-temperature zone and underlying upper dyke zone. 


\section{Fluid Flow and Water/Rock Ratios}

Within our field area, the channelways of descending fluids are not obvious. The lateral extent of pillowed units, massive flows, hyaloclastites, and breccias varies on a scale of tens to hundreds of meters, producing heterogeneous permeability. Local preservation of fresh volcanic glass adjacent to zones of intense alteration suggests that zones of high primary permeability, such as flow margins and small faults, locally focused the flow of seawater. Moreover, complex vein patterns show that the connectivity of fractures fluctuated as secondary minerals precipitated. The transition from lavas to sheeted dykes marked a change to strongly dyke-parallel fluid flow. In general, the intensity and pervasiveness of alteration is more uniform in the dykes than in the lavas, however, variable alteration within individual roadcuts suggests that fluid flow was locally focused. In western Troodos, intense alteration along the margins of some fault blocks indicates that these boundaries acted as conduits for the upward flow of hydrothermal solutions [Varga and Moores, 1985]. Presumably such zones could also focus recharging solutions.

Heterogeneous alteration has also been described for many ophiolites and drilled oceanic crust [Stern and Elthon, 1979; Bohlke et al., 1984; Harper et al., 1988]. In the Josephine ophiolite, these heterogeneites have been attributed to overprinting of discharge alteration on recharge zones and retrograde metamorphism associated with crustal cooling [Harper et al., 1988]. In Troodos, off-axis alteration and localized upflow of hydrothermal solutions certainly contribute to these heterogeneities; however, variable water/rock conditions, on a cooling unit to outcrop scale, are considered more important. Although these heterogeneities are prevalent in both the lavas and dykes, alteration is much more uniform in the dykes than the lavas. This probably reflects more uniform fluid flow in the dykes, perhaps due to their sheeted nature and a change in water/rock conditions at the lava-dyke transition. Permeability measurements in DSDP/ODP basement cores also indicate that the bulk permeability of the oceanic crust is strongly influenced by fractures and that the lava-dyke transition may mark a permeability boundary [Becker, 1985]. The spatial variability of fracture systems and permeability in modern ocean crust, however, is very poorly constrained.

Water/rock conditions inferred from bulk rock compositions. An alterative approach to investigating water/rock conditions in hydrothermal systems is to quantify bulk rock compositional change associated with alteration [e.g., Thompson, 1983]. Because such calculations assume initial rock and fluid compositions, complete exchange between rock and fluid, the path of fluid flow, and the nature of the hydrothermal system (i.e., open versus closed), the results indicate qualitative water/rock conditions. Bulk rock compositional changes relative to fresh rock values reflect the cumulative effects of many stages of alteration and cannot be used to predict water/rock conditions during a particular stage of alteration. Moreover, experimental studies indicate that water/rock ratios are specific for a particular element or isotope, depending where the element is located in the rock [Berndt et al., 1988]. O-isotopic contents of altered rocks are perhaps the most sensitive measure of system integrated waterrock exchange. Path-dependent and kinetic models based on $\delta^{18} \mathrm{O}$ can be utilized to predict fluid-rock exchange during the evolution of hydrothermal systems [Gregory and Criss, 1986].

Previous water/rock calculations for Troodos lavas and dykes show a wide range in values, from $>1000$ to 1 , and a gradual decrease in water/rock ratios with depth [Spooner et al., 1977; Heaton and Sheppard, 1977; Chapman and Spooner, 1977; Adamides, 1987; Richardson et al., 1987; Rommel and Friedrichsen, 1987; Bednarz and Schmincke, 1991]. An Oisotopic study in western Troodos shows a complex pattern of fluid flow in the lavas and dykes which suggests that water/rock conditions varied spatially and were not solely a function of depth [Schiffman and Smith, 1988].

The geochemical data collected in this study does not allow for quantitative water/rock calculations. Bulk compositional trends documented in the preceding section, however, do indicate qualitative water/rock conditions. At lowtemperatures, mobile elements such as $\mathrm{Rb}$ and $\mathrm{K}$ are removed from seawater and incorporated into secondary phases [Richardson et al., 1980; Staudigel et al., 1981; Seyfried et al., 1984; Berndt and Seyfried, 1986]. Water/rock ratios may be calculated using bulk rock compositions if it is assumed that the difference between fresh and altered rock values reflects the amount of seawater seen by the rocks. Because this method also assumes that the rocks reacted with chemically unmodified seawater and complete removal of these elements from seawater, the results are minimum values. Water/rock ratios calculated using $\mathbf{R b}$ and $\mathrm{K}$ contents of altered rocks from hole CY1/1A show a wide range in values but are generally higher in the seafloor weathering zone than the low-temperature zone (Table 11). Preferential uptake of $\mathrm{Rb}$ over $\mathrm{K}$ in smectite [Staudigel et al., 1981] probably contributed to higher water/rock ratios calculated using $\mathbf{R b}$ content relative to ratios calculated using $\mathbf{K}$.

TABLE 11. Calculated Water/Rock Ratios for Hole CY1/1A

\begin{tabular}{|c|c|c|c|}
\hline $\begin{array}{c}\text { Alteration } \\
\text { Zone }\end{array}$ & $\overline{\mathbf{K}}$ & $\overline{\mathrm{Rb}}$ & $\begin{array}{r}87 \mathrm{Sr} /{ }^{86} \mathrm{Sr} \\
\text { Ratios }\end{array}$ \\
\hline SWZ & $\begin{array}{c}59 \\
(0-116)\end{array}$ & $\begin{array}{c}196 \\
(0-415)\end{array}$ & $\begin{array}{c}38 \\
(7-141)\end{array}$ \\
\hline LTZ & $\begin{array}{c}32 \\
(0-146) \\
\end{array}$ & $\begin{array}{c}112 \\
(0-290)\end{array}$ & $\begin{array}{c}3 \\
(0-4) \\
\end{array}$ \\
\hline
\end{tabular}

Range of water/rock ratios are given in parentheses; $\mathrm{K}$ and $\mathrm{Rb}$ whole rock data for CY1/1A are from Robinson et al. [1990]; fresh rock $\mathrm{K}$ and $\mathrm{Rb}$ [Rautenschlein et al., 1985]; seawater $\mathrm{K}$ and $\mathrm{Rb}$ are from Bruland [1983]

At higher temperatures, the alkali and alkaline earth elements become incompatible in secondary phases and are strongly partitioned into the fluid [Seyfried et al., 1984; Von Damm et al., 1985]. In the absence of fluid compositions, it is not possible to calculate water/rock ratios based on the degree of depletion of these elements in the rocks. Moreover, because there is no evidence for quantitative removal of any elements from seawater or seawater-derived solutions at high temperatures, it is not possible to calculate water/rock ratios based on whole rock compositions. Comparison with experimental studies, however, suggests that Na-enrichment and $\mathrm{Ca}$-depletion documented for the upper dyke zone reflect low water/rock or rock-dominated conditions [Mottl, 1983].

$\mathrm{Sr}$ Isotopes. Sr-isotopic compositions of whole rocks have been used to investigate water/rock conditions in many fossil hydrothermal systems [e.g., McCulloch et al., 1981]. Recent experimental studies indicate that $\mathrm{Sr}$-isotopic ratios of altered rocks primarily reflect the amount of Sr-bearing phases converted or recrystallized to secondary phases and do not solely indicate water/rock conditions [Berndt et al., 1988]. However, ${ }^{87} \mathrm{Sr} /{ }^{86} \mathrm{Sr}$ ratios of altered rocks do provide important information concerning exchange reactions between fluids and Sr-bearing phases such as plagioclase.

The Sr-isotopic content of altered rocks from holes CY1/1A and CY2A fall between Cretaceous seawater (0.7076 [Hess et al., 1986]) and fresh volcanic glasses (average of two geochemical suites: 0.7036 [Rautenschlein et al., 1985]) (Figure 10; Table 12). Higher ratios in the seafloor weathering zone are attributed to higher primary permeability toward the 
A. Hole CYI/1A

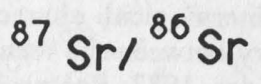

0.704

0.706

0.708

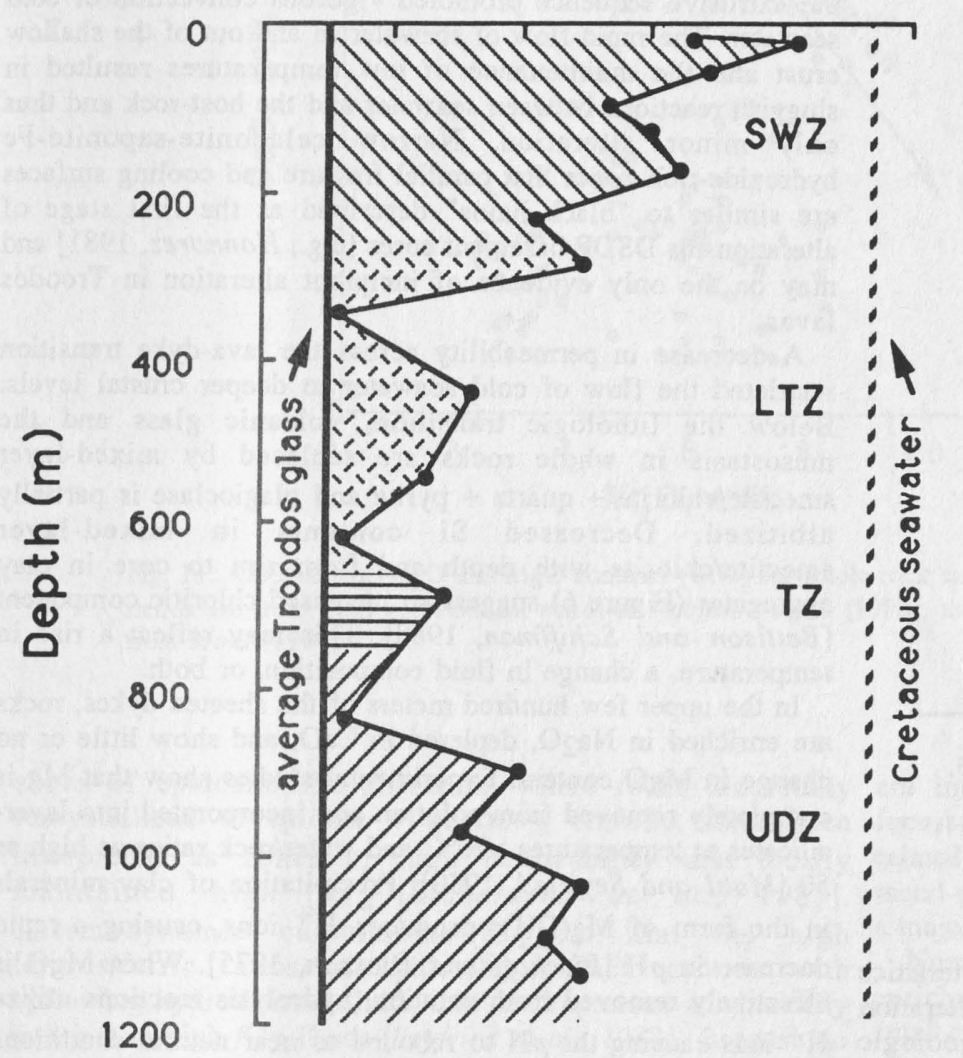

B. Hole CY2A

\section{${ }^{87} \mathrm{Sr} /{ }^{86} \mathrm{Sr}$}

0.704

0.706

0.708

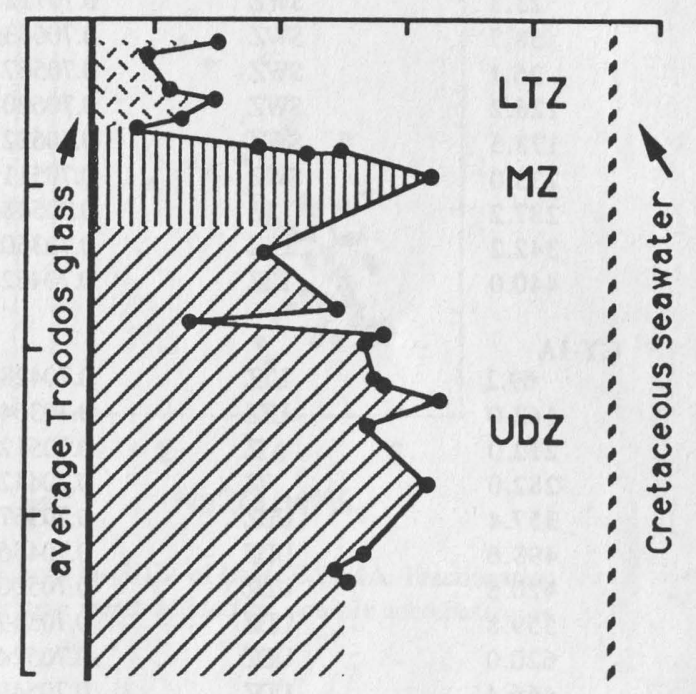

Fig. 10. Whole rock ${ }^{87} \mathrm{Sr} /{ }^{86} \mathrm{Sr}$ ratios versus depth in $(a)$ hole CY1/CY1A and $(b)$ hole CY2A. Data for hole CY1/1A, Table 9; hole CY2A, Rommel and Friedrichsen [1987]. Zone abbreviations are given in Table 1. The average Sr-isotopic composition of fresh volcanic glass is from Rautenschlein et al. [1985]; Cretaceous seawater values are from Hess et al. [1986]. Note that the values in the UDZ are generally higher than in the overlying LTZ.

top of the extrusive sequence due to the concentration of breccias [Schmincke et al., 1983; Robinson et al., 1991]. Moreover, almost complete replacement of plagioclase by $\mathrm{K}$ feldspar in this zone may also promote isotopic exchange. Pervasive calcite deposition in the seafloor weathering zone might also be expected to contribute to the high ${ }^{87} \mathrm{Sr} /{ }^{86} \mathrm{Sr}$ ratios as carbonates in the oceanic crust generally have $\mathrm{Sr}$ isotopic compositions close to seawater [Staudigel et al., 1981; Staudigel and Hart, 1985]; however, whole rock ${ }^{87} \mathrm{Sr} /{ }^{86} \mathrm{Sr}$ ratios show no positive correlation with $\mathrm{CO}_{2}$ content. ${ }^{87} \mathrm{Sr} /{ }^{86} \mathrm{Sr}$ ratios in the low-temperature zone are generally lower than the seafloor weathering zone but have a wider range in value and are interpreted to reflect the wide variation in the intensity of alteration typical of this zone and the erratic replacement of plagioclase by $\mathrm{K}$-feldspar. In the upper dyke zone, $\mathrm{Sr}$-isotopic ratios are slightly higher than in the overlying zones (Figure 10). Because lower water/rock conditions are expected in the sheeted dykes, the higher ${ }^{87} \mathrm{Sr} /{ }^{86} \mathrm{Sr}$ ratios may be the result of complete albitization of plagioclase which promoted greater isotopic exchange.

The Sr-isotopic depth profile of hole CY1/1A is remarkably similar to those of hole CY2A (Figure 10) and DSDP hole 504B [Barrett and Friedrichsen, 1982; Friedrichsen, 1985]. Holes CY2A and 504B both intersected fossil upwelling zones that did not vent on the seafloor [Honnorez et al., 1985; Alt et al., $1986 a$; Adamides, 1987]. Metal-enrichment in some rocks from the upper dyke zone of hole CY1/1A (Figure 9) suggests that the drillcore also intersected a zone of upwelling [Gillis and Robinson, 1991b]. Because modern hydrothermal fluids venting at mid-ocean ridges typically have ${ }^{87} \mathrm{Sr} /{ }^{86} \mathrm{Sr}$ ratios close to fresh rock values [Michard et al., 1984], higher ratios in the rocks underlying these mineralized zones suggests reaction with a seawater-dominated solution rather than an oreforming hydrothermal fluid. Alternatively, these higher ratios may also reflect a different evolutionary path for the fluids altering the rocks in these cores than hydrothermal fluids venting at mid-ocean ridges.

Field observations and geochemical trends indicate distinct water/rock conditions in the lavas and dykes of Troodos. Bulk rock compositional changes combined with field observations and permeability measurements in modern oceanic crust suggest that the lava-dyke boundary marks a change water/rock conditions with higher water/rock ratios in the lavas than the dykes. Moreover, comparison of bulk geochemical trends for rocks in the seafloor weathering zone and low-temperature zone suggests that water/rock ratios were greatest in the uppermost lavas. These conclusions, although speculative, represent our best estimate of water/rock conditions. 
TABLE 12. Whole Rock ${ }^{87} \mathrm{Sr} /{ }^{86} \mathrm{Sr}$ Ratios for Hole CY1/1A

\begin{tabular}{|c|c|c|}
\hline $\begin{array}{c}\text { Depth, } \\
\mathrm{m}\end{array}$ & $\begin{array}{r}\text { Alteration } \\
\text { Zone } \\
\end{array}$ & ${ }^{87} \mathrm{Sr} /{ }^{86} \mathrm{Sr}$ \\
\hline \multicolumn{3}{|l|}{ CY-1 } \\
\hline 19.7 & SWZ & $0.70630 \pm 4$ \\
\hline 23.3 & SWZ & $0.70712 \pm 3$ \\
\hline 58.7 & SWZ & $0.70643 \pm 4$ \\
\hline 96.1 & SWZ & $0.70567 \pm 3$ \\
\hline 126.2 & SWZ & $0.70600 \pm 5$ \\
\hline 173.5 & SWZ & $0.70622 \pm 3$ \\
\hline 233.0 & SWZ & $0.70511 \pm 4$ \\
\hline 287.2 & LTZ & $0.70548 \pm 4$ \\
\hline 342.2 & LTZ & $0.70360 \pm 3$ \\
\hline 440.0 & LTZ & $0.70462 \pm 6$ \\
\hline \multicolumn{3}{|l|}{ CY-1A } \\
\hline 69.2 & LTZ & $0.70428 \pm 4$ \\
\hline 142.0 & LTZ & $0.70364 \pm 3$ \\
\hline 212.0 & $\mathbf{z}$ & $0.70512 \pm 7$ \\
\hline 282.0 & $\bar{Z}$ & $0.70442 \pm 4$ \\
\hline 357.4 & UDZ & $0.70367 \pm 3$ \\
\hline 493.6 & UDZ & $0.70456 \pm 4$ \\
\hline 420.6 & UDZ & $0.70500 \pm 4$ \\
\hline 559.8 & UDZ & $0.70549 \pm 3$ \\
\hline 620.0 & UDE & $0.70524 \pm 3$ \\
\hline 666.4 & UDZ & $0.70549 \pm 3$ \\
\hline
\end{tabular}

Initial ratios corrected to 88 m.y.; 2-sigma errors are $\times 10^{5}$.

\section{DISCUSSION}

The distinct mineralogical and geochemical characteristics documented in the previous sections for each of the alteration zones are the end-products of a dynamic hydrogeologic environment. Complex vein patterns and precipitation sequences result from progressively changing physical and chemical processes whose products affect the processes that formed them [Norton, 1984]. Despite this complexity, it is possible to unravel many aspects of the alteration history of the lavas and dykes of the Troodos ophiolite. In the following sections, the conditions of alteration during progressive alteration are inferred through comparison of mineral assemblages and bulk compositional changes with basement cores recovered from modern oceanic crust and experimental studies. We present a model for the growth of alteration zones in Troodos during hydrothermal alteration, crustal aging, and the subsequent uplift and emplacement of the ophiolite.

\section{Axial Hydrothermal Alteration}

The occurrence of ore deposits at all but the highest stratigraphic levels in the extrusive sequence shows that numerous hydrothermal cells were active in the Troodos oceanic crust. Three major ore camps are recognized along the northern flank of the ophiolite which may reflect the location of fossil ridges [e.g., Varga and Moores, 1985] or pulses of hydrothermal activity triggered by cyclic or episodic magmatic intrusion. Late-stage dykes that cut across many ore deposits [Constantinou, 1980] and truncate epidosite zones [Richardson et al., 1987] show that most of the ore deposits formed prior to the cessation of volcanism. Textural evidence shows that most hydrothermal systems vented at the seafloor; only a few deposits are interpreted as replacement deposits [Constantinou, 1980; Robinson et al., 1987]. The association of most of these zones with faults indicates that the upward flow of hydrothermal solutions was structurally controlled [Constantinou, 1980; Adamides, 1987]. Below mineralized stockwork zones, upflow zones can generally be traced into the sheeted dyke complex [Richardson et al., 1987]. Geochemical and mineralogical characteristics indicate that the lateral boundary between the recharge and discharge zones was sharp [Adamides, 1987; Robinson et al., 1987].

During crustal construction, high primary permeability in the extrusive sequence promoted vigorous convection of cold seawater. The rapid flow of seawater in and out of the shallow crust and the maintenance of low temperatures resulted in sluggish reactions between seawater and the host-rock and thus only minor alteration. Narrow celadonite-saponite-Fe hydroxide-rich zones that parallel fracture and cooling surfaces are similar to "black halos" described as the first stage of alteration for DSDP basement cores [e.g., Honnorez, 1981] and may be the only evidence of incipient alteration in Troodos lavas.

A decrease in permeability across the lava-dyke transition restricted the flow of cold seawater to deeper crustal levels. Below the lithologic transition, volcanic glass and the mesostasis in whole rocks are replaced by mixed-layer smectite/chlorite + quartz + pyrite and plagioclase is partially albitized. Decreased $\mathrm{Si}$ contents in mixed-layer smectite/chlorite with depth and from rim to core in clay aggregates (Figure 6) suggest an increased chloritic component [Bettison and Schiffman, 1988]. This may reflect a rise in temperature, a change in fluid composition, or both.

In the upper few hundred meters of the sheeted dykes, rocks are enriched in $\mathrm{Na}_{2} \mathrm{O}$, depleted in $\mathrm{CaO}$, and show little or no change in $\mathrm{MgO}$ content. Experimental studies show that $\mathrm{Mg}$ is completely removed from solution and incorporated into layersilicates at temperatures $>70^{\circ} \mathrm{C}$ and water/rock ratios as high as 50 [Mottl and Seyfried, 1980]. Precipitation of clay minerals in the form of $\mathrm{Mg}(\mathrm{OH})_{2}$ produces $\mathrm{H}^{+}$ions, causing a rapid decrease in $p \mathrm{H}$ [Bischoff and Dickson, 1975]. When $\mathrm{MgO}$ is effectively removed from solution, hydrolysis reactions utilize $\mathrm{H}^{+}$ions causing the $p \mathrm{H}$ to rebound to near neutral conditions [Seyfried and Bischoff, 1977]. The only evidence of early acidic conditions is minor metal-depletion in the altered rocks [Rosenbauer and Bischoff, 1983; Baragar et al., 1987].

Experiments predict that removal of $\mathrm{Mg}$ and, to a lesser extent, $\mathrm{Na}_{2} \mathrm{O}$ from solution is balanced with respect to electrical charge by leaching $\mathrm{Ca}$ from the rock [Mottl and Holland, 1978]. Oceanic metabasalts show a negative correlation between $\mathrm{CaO}$ and $\mathrm{MgO}$ content with a slope of -1 $\mathrm{CaO} / \mathrm{MgO}$ [Mottl, 1983]. In the upper dyke zone of hole CY1/1A, however, there is no correlation between $\mathrm{CaO}$ and $\mathrm{MgO}$, and $\mathrm{MgO}$ contents generally fall below the alteration trend defined by the oceanic metabasalts (Figure 11). Negative correlation between $\mathrm{CaO}$ and $\mathrm{Na}_{2} \mathrm{O}$ suggests $\mathrm{Ca}$-depletion is balanced by exchange with $\mathrm{Na}$ (Figure 11). $\mathrm{Ca}-\mathrm{Na}$ exchange and the lack of significant $\mathrm{Mg}$ enrichment implies formation under low water/rock conditions [Mottl, 1983].

Rocks in the upper dyke zone are typically altered to assemblages of chlorite + quartz + albite \pm pyrite \pm epidote. The presence of quartz in the groundmass does not reflect increased whole rock $\mathrm{SiO}_{2}$ contents (Figure 9) but, rather, excess $\mathrm{SiO}_{2}$ released during chlorite formation [Mottl, 1983]. Complete albitization of plagioclase suggests interaction with a fluid with high $\mathrm{Na}^{+} / \mathrm{Mg}^{+}$contents [Seewald, 1987]. Concentration of chlorite toward the margins of pillows may have locally depleted the fluid in $\mathbf{M g}$ and thus would have promoted albitization. Reaction with Mg-poor, Si-rich hydrothermal solutions also promotes albitization [Seyfried et al., 1988] as evidenced by the presence of albite below most mineralized zones and in the rocks surrounding epidosites [Schiffman and Smith, 1988].

Whole rock ferrous/ferric ratios close to fresh rock values indicate that the fluids were depleted in $\mathrm{O}_{2}$. However, small 

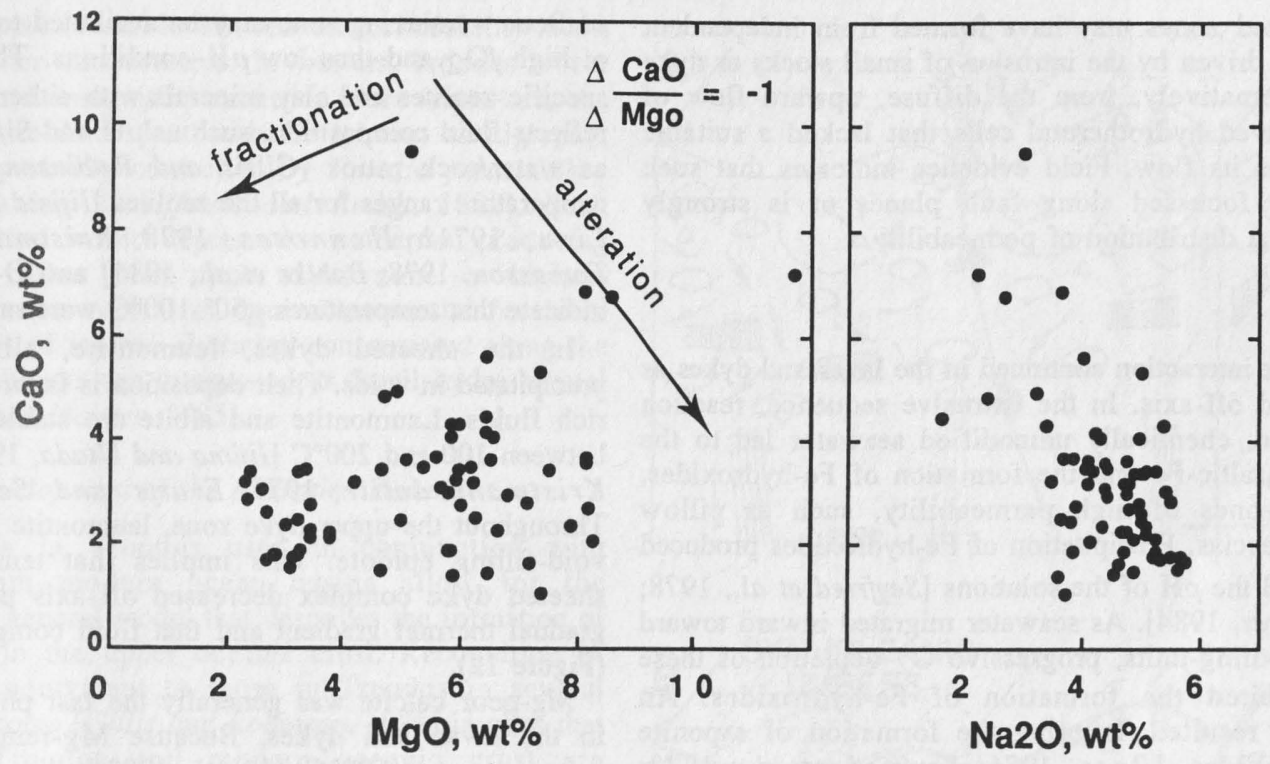

Fig. 11. $\mathrm{CaO}$ versus $\mathrm{Na}_{2} \mathrm{O}$ and $\mathrm{MgO}$ contents (wt\%) for whole rock samples from the $\mathrm{UDZ}$ of holes $\mathrm{CY} 1 / 1 \mathrm{~A}$. Fractionation trends are from both geochemical suites of Robinson et al. [1983]; the alteration trend defined by oceanic metabasalts is from Mottl [1983].

zones of epidosite-like alteration, where rocks are totally are interpreted as zones of high primary permeability that recrystallized to epidote + quartz \pm chlorite, have been focussed recharging solutions. Although no epidosite has been interpreted as zones of high permeability that locally related to a specific ore deposit, calculations indicate that these maintained high fO 2 [Richardson et al., 1987]. metal-depleted rocks could supply the metals necessary to form Thermodynamic calculations suggest that the high a major deposit [Richardson et al., 1987].

ferrous/ferric ratios of epidosites reflect reaction with upflowing hydrothermal fluids that decompressed adiabatically rather than high $\mathrm{fO}_{2}$ fluids [Seyfried et al., 1988]. Because no other evidence indicates high $\mathrm{fO}_{2}$ in the sheeted dykes, we favor the latter interpretation.

Similar major element compositions of both void-filling and groundmass-replacing epidote (Figure 8) suggest precipitation from similar fluids at similar temperatures [Liou et al., 1985]. Thus precipitation of epidote, quartz, and pyrite in voids was probably coeval with groundmass alteration in the dykes.

$\mathrm{O}$-isotopic contents for smectite and celadonite indicate temperatures $<70^{\circ} \mathrm{C}$ and for chlorite $80^{\circ}-240^{\circ} \mathrm{C}$. The transition from saponite to mixed-layer smectite/chlorite in the Icelandic geothermal fields occurs at temperatures between $100-200^{\circ} \mathrm{C}$ and from mixed-layer smectite/chlorite to chlorite between $200-240^{\circ} \mathrm{C}$ [Kristmannsdottir, 1975]. Fluid inclusion data for quartz and $\delta^{18} \mathrm{O}$ contents of quartz-epidote pairs indicate temperatures $>240^{\circ} \mathrm{C}$; epidote is stable at temperatures $>200^{\circ} \mathrm{C}$ in geothermal systems [Kristmannsdottir, 1975; Bird et al., 1984; Liou et al., 1985]. Albite is stable at temperatures between 140 and $300^{\circ} \mathrm{C}$; the anorthite content in plagioclase increases with increasing temperature (see Seyfried et al. [1988] for further discussion).

The sheeted dykes subjacent to the lava-dyke transition are generally altered to calcic plagioclase, amphibole, and chlorite [Baragar et al., 1987]. This assemblage implies alteration under low water/rock conditions and temperatures $>300^{\circ} \mathrm{C}$ [Mottl and Holland, 1978]. These relations indicate a sharp rise in temperature, from $<50^{\circ}$ in the lavas to $>150^{\circ} \mathrm{C}$ across the lithologic transition and to $>300^{\circ} \mathrm{C}$ in the uppermost dykes, producing a stepped thermal gradient (Figure 12).

Large epidosite bodies $\left(3-25 \mathrm{~km}^{3}\right)$, generally concentrated toward the base of the sheeted dyke complex, are interpreted as the root-zones and conduits of fossil hydrothermal systems [Richardson et al., 1987; Schiffman et al., 1987]. These bodies

Numerous small zones of mineralization and metal enrichment within the lavas and sheeted dykes suggest that small-scale convection cells were also active at the ridge axis.

\section{Temperature ${ }^{\circ} \mathrm{C}$}

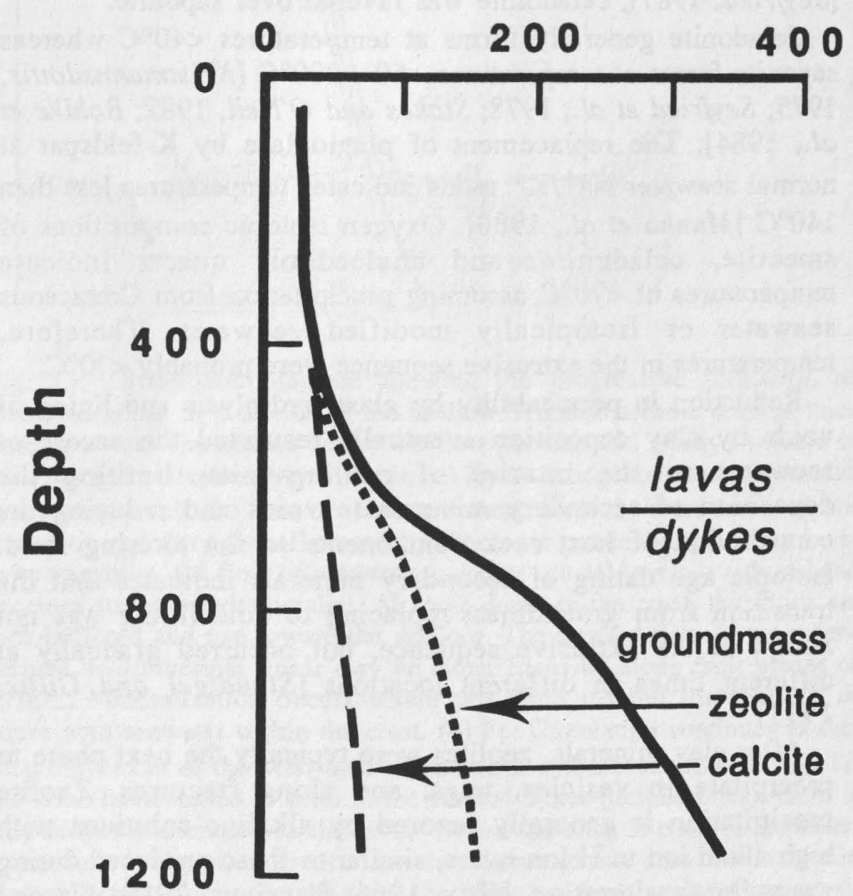

Fig. 12. Estimated themal gradients for holes CY1/1A at different stages of alteration. See text for discussion. 
These mineralized zones may have formed from independent circulation cells driven by the intrusion of small stocks or dyke swarms or, alternatively, from the diffuse, upward flow of larger, longer-lived hydrothermal cells that lacked a suitable conduit to focus its flow. Field evidence indicates that such flow is locally focussed along fault planes or is strongly influenced by the distribution of permeability.

\section{Crustal Aging}

Seawater-rock interaction continued in the lavas and dykes as the crust moved off-axis. In the extrusive sequence, reaction with oxygenated, chemically unmodified seawater led to the oxidation of basaltic-Fe and the formation of Fe-hydroxides, especially in zones of high permeability, such as pillow margins and breccias. Precipitation of Fe-hydroxides produced $\mathrm{H}^{+}$and lowered the $\mathrm{pH}$ of the solutions [Seyfried et al., 1978; Alt and Honnorez, 1984]. As seawater migrated inward toward the cores of cooling-units, progressive $\mathrm{O}_{2}$ depletion of these solutions inhibited the formation of Fe-hydroxides. An increase in $p \mathrm{H}$ resulted, favoring the formation of saponite over Fe-hydroxides [Bass, 1976; Seyfried et al., 1978; Andrews, 1980] and the replacement of plagioclase by Kfeldspar [Alt and Honnorez, 1984]. Decreases in the abundance of Fe-hydroxides and lower whole-rock ferrous/ferric ratios with depth (Figures 2 and $9 b$ ) show that $\mathrm{O}_{2}$ in solution was progressively depleted as seawater migrated downward.

The association of celadonite primarily with massive flows and intrusive contacts suggests that distinct conditions prevailed in these units relative to pillows. High $\mathrm{SiO}_{2}(\mathrm{aq})$ concentrations coupled with low $p \mathrm{H}$ and oxidative conditions favour the formation of celadonite [Wise and Eugster, 1964]. The concentration of alteration along the margins of massive flows and intrusives suggests that fluid flow was focussed along these zones. In contrast, the radial fracture patterns in pillows led to more diffuse fluid flow. It may be inferred, therefore, that fluid compositions along flow margins were primarily controlled by glass alteration whereas fluids altering pillows contained both glass and crystalline rock components. Because $\mathrm{SiO}_{2}$ is released into solution more readily from glass [Seyfried, 1987], celadonite was favored over saponite.

Celadonite generally forms at temperatures $<40^{\circ} \mathrm{C}$ whereas saponite forms at temperatures $<50-200^{\circ} \mathrm{C}$ [Kristmannsdottir, 1975; Seyfried et al., 1978; Stakes and O'Neil, 1982; Bohlke et al., 1984]. The replacement of plagioclase by K-feldspar at normal seawater $\mathrm{Na}^{+} / \mathrm{K}^{+}$ratios indicates temperatures less than $140^{\circ} \mathrm{C}$ [Munha et al., 1980]. Oxygen isotopic compositions of smectite, celadonite, and chalcedonic quartz indicate temperatures of $<70^{\circ} \mathrm{C}$ assuming precipitation from Cretaceous seawater or isotopically modified seawater. Therefore, temperatures in the extrusive sequence were probably $<70^{\circ} \mathrm{C}$.

Reduction in permeability by glass hydrolysis and lining of voids by clay deposition eventually restricted the access of seawater to the interior of cooling-units, limiting the deposition of secondary minerals to voids and reducing the contribution of host rock components to the altering fluid. Isotopic age dating of secondary minerals indicates that the transition from groundmass-replacing to void-filling was not abrupt in the extrusive sequence, but occurred gradually at different times in different locations [Staudigel and Gillis, 1991].

After clay minerals, zeolites were typically the next phase to precipitate in vesicles, vugs, and along fractures. Zeolite precipitation is generally favored by alkaline solutions with high alkali ion to $\mathrm{H}$ ion ratios, similar to those produced during groundmass alteration [Hay, 1966; Barrows, 1980; Alt and Honnorez, 1984]. In the extrusive sequence, zeolites are most abundant in the low-temperature zone. Their scarcity in the seafloor weathering zone may be attributed to the maintenance of high $\mathrm{fO}_{2}$ and thus low $p \mathrm{H}$ conditions. The association of specific zeolites and clay minerals with either pillows or flows reflects fluid composition, such as $p \mathrm{H}$ and $\mathrm{Si} / \mathrm{Al}$ ratios, as well as water/rock ratios [Gillis and Robinson, 1991a]. Stable temperature ranges for all the zeolites [Iijima and Utada, 1971; Liou, 1971b; Honnorez, 1978; Kristmannsdottir and Tomasson, 1978; Bohlke et al., 1984] and O-isotopic contents indicate that temperatures $\leq 50^{\circ}-100^{\circ} \mathrm{C}$ were maintained.

In the sheeted dykes, laumontite, albite, and quartz precipitated in voids. Their deposition is favored by $\mathrm{Ca}$ - and $\mathrm{Si}$ rich fluids. Laumontite and albite are stable at temperatures between 100 and $200^{\circ} \mathrm{C}$ [Iijima and Utada, 1971; Liou, 1971a; Kristmannsdottir, 1975; Evarts and Schiffman, 1983] Throughout the upper dyke zone, laumontite locally overprints void-filling epidote. This implies that temperatures in the sheeted dyke complex decreased off-axis producing a more gradual thermal gradient and that fluid compositions changed (Figure 12).

$\mathrm{Mg}$-poor calcite was generally the last phase to precipitate in the lavas and dykes. Because $\mathrm{Mg}$-removal is rapid at temperatures $>100^{\circ} \mathrm{C}$ [Mottl, 1983], the altering solutions must have reacted with rock prior to carbonate precipitation. ${ }^{87} \mathrm{Sr} /{ }^{86} \mathrm{Sr}$ ratios of carbonates from all alteration zones [Staudigel and Gillis, 1991; K.M. Gillis, unpublished data, 1989] indicate precipitation from seawater-dominated solutions rather than ore-forming hydrothermal solutions. Temperatures increased gradually from those of Cretaceous bottom water $\left(5-15^{\circ} \mathrm{C}\right.$ [Brass et al., 1982]) to approximately $80^{\circ} \mathrm{C}$ in the dykes (Figure 12 ).

\section{Alteration Patterns versus Regional Structure}

Alteration equivalent to that in our field area has been described for the Solea Graben in western Troodos [Schiffman et al., 1987; Schiffman and Smith, 1988], however, alteration zones in the Solea Graben are highly discordant with the igneous stratigraphy [Varga and Moores, 1985]. Along the eastern flank of the graben, transition zone alteration extends down to the lower 1-2 km of the sheeted dyke complex whereas upper dyke zone alteration dominates the western flank of the graben [Schiffman and Smith, 1988]. The higher temperature alteration in the western flank is attributed to a late-stage hypabyssal intrusion that postdates spreading [Schiffman and Smith, 1988].

Paleomagnetic [Allerton and Vine, 1987] and structural studies [Varga and Moores, 1985; Hurst et al., 1987] in western Troodos show that fault blocks were rotated, possibly along listric normal faults. Field relations suggest that tectonism postdated dyke injection [Schiffman and Smith, 1988] and that spreading was accommodated by alternating magmatic and amagmatic extension [Varga and Moores, 1985]. In contrast, the structure within our field area is relatively simple with nearly vertical dykes and less than $100 \mathrm{~m}$ off-sets along dykeparallel faults [Boyle and Robertson, 1984; Eddy and Moores, 1987]. Fault block rotations generally less than $30^{\circ}$ indicate that extension was accommodated mainly by extrusion and dyke intrusion [Allerton and Vine, 1987]. Thus the original seafloor topography was probably subdued and the lava-dyke boundary fairly laterally continuous.

Contrasting alteration patterns along the northern flank of Troodos must reflect the thermal and hydrologic conditions associated with different spreading histories. Where extension was primarily accommodated by magmatic intrusion, such as our field area, the alteration zones and the igneous stratigraphy (i.e., lava-dyke transition) have a consistent, laterally continuous, depth succession. Diffuse recharge was controlled by lithologic permeability and small-offset faults. High permeability in the lavas depressed the thermal gradient 
imposed from deeper crustal levels; reduced permeability in the dykes led to higher temperatures. In western Troodos where both magmatic and amagmatic extension were important, the alteration zones are discordant with the igneous stratigraphy. Fluid flow was probably controlled by fracture permeability produced by faulting [Schiffman and Smith, 1988]. Such enhanced circulation would depress the isotherms, producing transition zone rather than upper dyke zone or highertemperature alteration typical of equivalent crustal levels in other areas. Zones of intense alteration concentrated along the margins of fault blocks are interpreted as fossil hydrothermal conduits [Varga and Moores, 1985].

\section{Model for the Development of the Alteration Zones}

Field relations in Troodos used in conjunction with observations from modern ocean basins allow for the development of a general model that describes the formation of alteration zones in the upper oceanic crust. Recognition of alteration zones equivalent to those in Troodos in several DSDP basement cores [Gillis and Robinson, 1988] implies that conditions in Troodos and modern oceanic crust are comparable. Details, such as the relative abundance of secondary minerals, will vary between and within different geographic locations because of the diversity of age and geologic setting as well as the general absence of equilibrium between solutions and host rocks.

Our model describes the progressive formation of alteration zones from crustal accretion until seawater-rock interaction and circulation ceased (Figure 13). In modern oceanic crust, heat flow measurements indicate that open circulation continues until the upper crust is effectively sealed either by the deposition of a sedimentary cover thick enough to prevent seawater penetration or by the precipitation of secondary minerals in voids [Anderson and Hobart, 1976]. In Troodos, the sedimentary sequence overlying the lavas was discontinuous along the northern flank of the ophiolite until at least the middle Miocene [Robertson, 1977]. Isotopic age dating of secondary minerals from the upper $500 \mathrm{~m}$ of the lavas suggests that mineral precipitation and, probably, seawater circulation ceased 10-20 m.y. after crustal formation [Staudigel et al., 1986; Staudigel and Gillis, 1991]. The duration of fluidrock interaction for in situ oceanic crust that formed in sediment-starved environments is similar to that in Troodos [Staudigel and Hart, 1985].

During crustal accretion in the Troodos oceanic crust, axial hydrothermal cells were driven by magmatic intrusion at depth in the crust. Within coherent tectonic blocks, the rapid flow of cold seawater in and out of the extrusive sequence contributed to the maintenance of low temperatures $\left(<50^{\circ} \mathrm{C}\right)$ and very little alteration. Lower permeability in the sheeted dykes restricted the flow of seawater producing lower water/rock conditions; the pattern of flow changed from random to strongly dyke-parallel (Figure 13a).

As seawater penetrated to deep crustal levels, it was chemically modified by reaction with the rocks through which it passed. At some depth in the crust, these recharging fluids were buffered by equilibrium reactions and rose toward the surface with little or no modification. Where structurally focussed, these hydrothermal fluids had the potential for venting on the seafloor. In the absence of a conduit, discharge was diffuse and mineralization occurred either along small faults or at the lava-dyke transition due to contact with cold seawater. There is no evidence of diffuse flow of metal-enriched hydrothermal fluids in the lavas, possibly because the compositional signature of the discharging hydrothermal fluids was obscured by recharging seawater.

Within recharge zones, the steep thermal gradient prevalent in the intrusives was depressed in the extrusive section. The
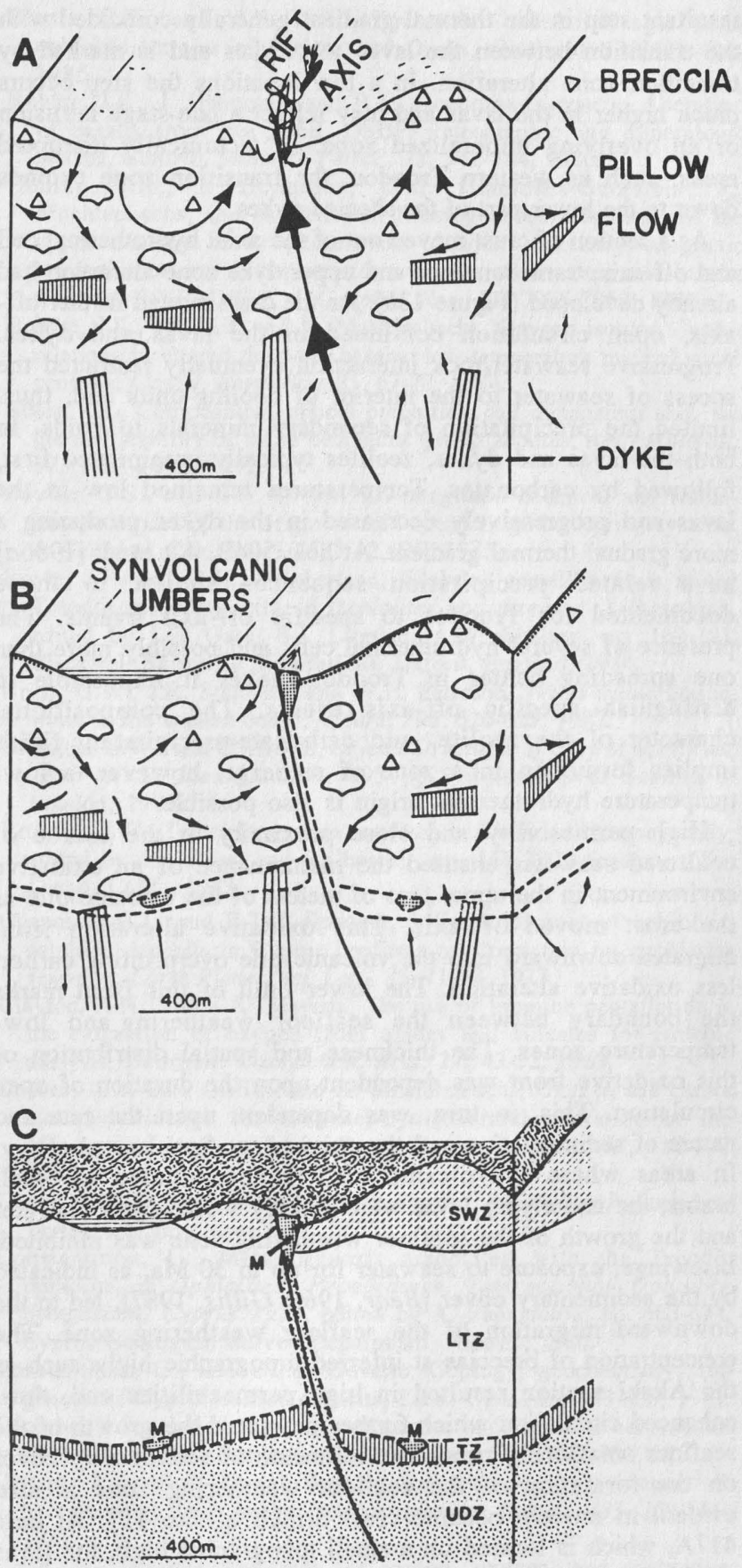

Fig. 13. Schematic diagram showing the progressive formation of alteration zones in a section of the shallow Troodos oceanic crust at three time intervals. The arrows depict the flow patterns and relative volume of seawater and seawater-derived fluids. (a) $T_{0}$ : At a ridge axis within the axial hydrothermal cell, the flow of seawater in and out of the extrusive sequence is chaotic and strongly influenced by lithologic permeability. At the lavadyke transition, the flow of seawater to deeper crustal levels is reduced and becomes strongly dyke-parallel. At some depth in the crust, the fluids are rock-buffered and rise toward the seafloor. The upward flow of seawaterderived, hydrothermal fluids may be either focussed along fault planes or diffuse. Mineralization occurs where this fluid reaches the seafloor or mixes with seawater within the crust. $(b) T_{1}$ : Circulation continues as the crust moves out of the axial hydrothermal cell and moves off-axis. The TZ and UDZ have started to form in the sheeted dykes (dashed lines); there is only incipient alteration in the lavas. Where the crust is open to seawater, an oxidative alteration front starts to migrate down into the lava pile (dotted line). (c) $T_{2}$ : By the time the crust has been sealed from open circulation and seawater-rock interaction had ceased, the alteration zones have formed. 
resultant step in the thermal gradient generally coincided with the transition between the lavas and dykes and is marked by transition zone alteration. In a few locations the step occurs much higher in the lavas and may reflect a late-stage intrusion or an overlying mineralized zone. In tectonically disrupted areas, such as western Troodos, the transition zone extends down to the lower part of the sheeted dykes.

As a section of crust moved out of the axial hydrothermal cell and off-axis, transition zone and upper dyke zone alteration had already developed (Figure $13 b$ ). As the crust moved further offaxis, open circulation continued in the lavas and dykes. Progressive seawater/rock interaction eventually restricted the access of seawater to the interior of cooling-units and, thus, limited the precipitation of secondary minerals to voids. In both the lavas and dykes, zeolites typically precipitated first, followed by carbonates. Temperatures remained low in the lavas and progressively decreased in the dykes producing a more gradual thermal gradient. At hole 504B, Alt et al. [1986a] have related precipitation sequences similar to those documented for Troodos to specific off-axis events. The presence of several hydrothermal cells and possibly more than one spreading center in Troodos makes it impossible to distinguish specific off-axis events. The compositional character of the zeolite- and carbonate-precipitating fluids implies formation in a zone of recharge, however, a lowtemperature hydrothermal origin is also possible.

High permeability and close proximity to the source of unaltered seawater ensured the maintenance of an oxidative environment in the upper tens of meters of the volcanic pile as the crust moved off-axis. This oxidative alteration front migrated downward into the volcanic pile overprinting earlier, less oxidative alteration. The lower limit of this front marks the boundary between the seafloor weathering and lowtemperature zones. The thickness and spatial distribution of this oxidative front was dependent upon the duration of open circulation. This, in turn, was dependent upon the rate and nature of sedimentation and the original seafloor morphology. In areas where synvolcanic umbers accumulated in small basins, the underlying lavas were quickly sealed from seawater and the growth of the seafloor weathering zone was inhibited. Elsewhere, exposure to seawater for up to $30 \mathrm{Ma}$, as indicated by the sedimentary cover [Bear, 1960; Gillis, 1987], led to the downward migration of the seafloor weathering zone. The concentration of breccias at inferred topographic highs such as the Akaki section resulted in high permeabilities and, thus, enhanced circulation which further promoted the growth of the seafloor weathering zone. The influence of sedimentary cover on the formation of the seafloor weathering zone is also evident in modern oceanic crust drilled at site 417 . At hole 417A, which is located on a small topographic high, the lavas were exposed to cold seawater for 10 to $20 \mathrm{~m}$.y., whereas at hole 417D, drilled $450 \mathrm{~m}$ away, sediments accumulated from the time of crustal accretion [Shipboard Scientific Crews, Legs 51$53,1979]$. As expected, the seafloor weathering zone in hole $417 \mathrm{~A}$ is well developed, whereas in $417 \mathrm{D}$ it is only a few meters thick. The seafloor weathering zone in hole 504B is not as well developed as in Troodos or in hole 417A. Closed circulation in this zone quickly depleted the fluid in $\mathrm{O}_{2}$ and thus inhibited oxidative alteration typical of the seafloor weathering zone.

\section{CONCLUSIONS}

A complex history of hydrothermal alteration, crustal aging and subsequent uplift and emplacement is recorded in the lavas and dykes of the Troodos ophiolite. Unlike many ophiolites, Troodos lacks a pervasive emplacement-related metamorphic overprint and thus, the low-temperature alteration is well preserved. Five alteration zones, each with distinct mineralogical, geochemical and hydrologic characteristics, are recognized. Although highly variable in thickness and lateral extent, these zones have consistent vertical relationships.

The earliest alteration is recorded in the mineralized zones, subvertical pipe-like bodies that mark zones of axial hydrothermal discharge. These zones are preserved as mineralized stockworks which underlie the massive sulfide ore bodies. During this stage of alteration, relatively cold sea water percolated downward into the lava pile, depressing the ambient temperature, thus limiting alteration cutside the stockwork zones. The stockwork zones grade downward into the upper dyke zone, in which recharging seawater reached temperatures of $>300^{\circ} \mathrm{C}$ promoting the formation of greenschist facies assemblages. A narrow zone of intermediate temperatures at the lava-dyke boundary is represented by the transition zone.

As crustal sections moved off axis, open circulation continued in the lavas and dykes. Temperatures remained low in the lavas and decreased progressively in the dykes, producing a more uniform thermal gradient. Continued deposition of clay minerals and zeolites in the lavas led to the development of the low temperature zone. As the crust moved even farther off-axis, downward percolation of cold, oxygenated seawater led to the formation of alteration associated with the seafloor weathering zone. In areas where the basaltic crust was sealed at an early stage by impermeable sediments, the seafloor weathering zone is thin or absent; where the crust was exposed to the sea floor for long periods this zone is relatively thick and well developed. The only evidence of late-stage alteration associated with uplift and emplacement of Troodos is the presence of a subvertical veins of gypsum and palygorskite that cross-cut the previously altered uppermost lavas.

The zones of alteration described above have also been recognized in drilled oceanic crust. This suggests that the hydrothermal processes recorded in the Troodos ophiolite are similar to those in modern oceanic crust despite the fact that the ophiolite formed in a supra-subduction zone environment. Consequently, the spatial relationships of alteration in Troodos may provide information on alteration patterns in modern ocean basins.

Acknowledgments. We thank the Cyprus Geological Survey Department for their continued support of the Cyprus Crustal Study Project and the many related field programs. We are particularly grateful to G. Constantinou, A. Panayioutou, C. Xenophontos, and N. Adamides for their introduction to the geology of Cyprus and their guidance during many field seasons. Our friends in Mitsero are sincerely thanked for their friendship and hospitality. Our ideas and understanding of alteration processes developed through many discussions with J. Mehegan, J. Honnorez, H. Staudigel, J. Cann, W. Baragar, R. Jamieson, M. Salisbury, J. Ludden, G. Thompson, M. Tivey, P. Meyer, and members of the CCSG. G. Brown produced excellent thin sections from extremely altered material, and R. MacKay assisted with probe analyses. K. Muehlenbachs and D. Scott are thanked for producing the stable isotope data. A. Smith and G. Gauthier provided guidance and encouragement in the radiogenic isotope lab. M. Sulanowska helped with the diagrams. This work is part of K.M.G.'s Ph.D. dissertation and was supported by Natural Sciences and Engineering Research Council of Canada grants to P.T.R. Critical reviews by $\mathrm{H}$. West and an anonymous reviewer greatly contributed to the presentation and clarity of this paper.

\section{REFERENCES}

Adamides, N.G., Diverse modes of occurrence of Cyprus sulphide deposits and comparison with recent analogues, Cyprus Crustal Study Project, Initial Report, holes CY-2 and CY-2A, Geol. Surv. Can. Pap., 85-29, 153-168, 1987.

Alabaster, T., and J.A. Pearce, The interrelationship between magmatic and ore-forming hydrothermal processes in the Oman ophiolite, Econ. Geol., 80, 1-16, 1985.

Allerton, S., and F.J. Vine, Spreading structure of the Troodos 
ophiolite, Cyprus: Some paleomagnetic constraints, Geology, 15 , 593-597, 1987.

Alt, J.C., and J. Honnorez, Alteration of the upper oceanic crust, DSDP site 417: Mineralogy and chemistry, Contrib. Minercal. Fetrol., 87, 149-169, 1984.

Alt, J.C., J. Honnorez, C. Laverne, and R. Emmerman, The structure and evolution of a submarine hydrothermal system: DSDP site 504B, J. Geophys. Res., 91, 10,309-10,335, 1986a.

Alt, J.C., K. Muehlenbachs, and J. Honnorez, An oxygen profile through the upper kilometer of the oceanic crust, DSDP hole 504B, Earth Planet. Sci. Lett., 80, 217-229, $1986 b$.

Andrews, A.J., Saponite and celadonite in layer 2 basalts, DSDP Leg 37, Contrib. Mineral. Petrol., 73, 323-340, 1980.

Anderson, R.N. and M.A. Hobart, The relation between heat flow, sediment thickness, and age in the eastem Pacific, J. Geophys. Res., 81, 2968-2989, 1976.

Bailey, D.M., Stratigraphy and geochemistry of the Troodos ophiolite extrusive sequence in the Margi area, Cyprus, M.Sc. thesis, 215 pp., Dalhousie Univ., Halifax, 1984.

Baragar, W.R.A., A.G. Plant, G.J. Pringle, and M. Schau, Petrology and alteration of selected units of Mid-Atlantic Ridge basalts sampled from sites 332 and 335, DSDP, Earth Planet. Sci. Lett., 14, 837-874, 1977.

Baragar, W.R.A., M.B. Lambert, N. Baglow, and I. Gibson, Sheeted dykes of the Troodos ophiolite, Cyprus, Mafic dyke swarms, Spec. Pap. Geol. Assoc. Can., 34, 257-272, 1987.

Baragar, W.R.A., F. Auclair, and J.N. Ludden, Alteration of the upper pillow lavas of the Troodos ophiolite: Evidence from the CY-1 drillcore of the ICRDG, Cyprus Crustal Study Project Initial Report, holes CY-1 and CY-1A, Spec. Pap., Geol. Surv. Can., in press, 1991.

Barrett, T.J., and H. Friedrichsen, Strontium and oxygen isotopic composition of some basalts from Deep Sea Drilling Project hole 504B, Costa Rica Rift, legs 69 and 70, Earth Planet. Sci. Lett., 60 , 27-38, 1982.

Barriga, F.J., J. Munha, W.S. Fyfe, N.J. Vibetti, and R. Kerrich, Subseafloor metamorphism down to Moho depths at Troodos, Cypras, Paper presented at Troodos '87: Ophiolites and Oceanic Lithosphere, Cyprus Geological Survey Department, Nicosia, Cyprus, October, 1987.

Barrows, K.J., Zeolitization of Miocene volcaniclastic rocks, southern Desatoya Mountains, Nevada, Geol. Soc. Am. Bull., 91, 199-210, 1980.

Bass, M.N., Secondary minerals in oceanic basalt, with special reference to Leg 34, Deep Sea Drilling Project, Initial Rep. Deep Sea Drill. Proj., 34, 393-432, 1976.

Bear, L.M., The geology and mineral resources of the AkakiLythrodonda area, Cyprus Geol. Surv. Mem., 3, 122 pp., 1960.

Becker, K., Large-scale electrical resistivity and bulk porosity of the oceanic crust, hole 504B, Costa Rica Rift, Initial Rep. Deep Sea Drill. Proj, 83, 419-428, 1985.

Bednarz, U., and H.-U. Schmincke, Chemical patterns of seawater and hydrothermal alteration in the northeastem Troodos extrusive series and sheeted dyke complex, Cyprus, in Troodos '87: Ophiolites and Oceanic Lithosphere Symposium Volume, edited by E.M. Moores, Cyprus Geological Survey Department., Nicosia, in press, 1991.

Belyie, V.M., A.A. Migdisov, N.V. Barskaya, and V.A. Grinenko, Sulfur isotope composition of hydrothermal sulfides from hole 504B, DSDP leg 70, Costa Rica Rift, Initial Rep. Deep Sea Drill. Proj., 83, 619-628, 1983.

Berndt, M.E., and W.E. Seyfried Jr., B, Li and associated trace element chemistry of alteration minerals, holes 597B and 597C, Initial Rep. Deep Sea Drill. Proj., 92, 491-497, 1986.

Berndt, M.E., W.E. Seyfried, Jr., and J.W. Beck, Hydrothermal alteration processes at mid-ocean ridges: Experimental and theoretical constraints from $\mathrm{Ca}$ and $\mathrm{Sr}$ exchange reactions and $\mathrm{Sr}$ isotopic ratios, J. Geophys. Res., 93, 4573-4583, 1988.

Bettison, L.A. and P. Schiffman, Compositional and structural variations of phyllosilicates from the Point Sal ophiolite, California, Am. Mineral., 73, 186-229, 1988.

Bird, D.K., P. Schiffman, W.A. Elders, A.E. Williams, and S.D. McDowell, Calc-silicate mineralization in active geothermal systems, Econ. Geol., 79, 671-695, 1984.

Bischoff, J.L., and F.W. Dickson, Seawater-basalt interaction at $200^{\circ} \mathrm{C}$ and 500 bars: Implications for origin of sea-floor heavy-metal deposits and regulation of seawater chemistry, Earth Planet. Sci. Lett., 278, 838-860, 1975.
Blome, C.D., and W.P. Irwin, Equivalent radiolarian ages from ophiolite terrains of Cyprus and Oman, Geology, 13, 401-404, 1985.

Bohlke, J.K., J. Honnorez, and B.M. Honnorez-Guerstein, Alteration of basalts from site 396B, DSDP: Petrographic and mineralogic studies, Contrib. Mineral. Petrol., 73, 341-364, 1980.

Bohlke, J.K., J. Honnorez, B.M. Honnorez-Guerstein, K. Muehlenbachs, and N. Petersen, Heterogeneous alteration of the upper oceanic crust: Correlation of rock chemistry, magnetic properties, and $\mathrm{O}$ isotopic ratios with alteration pattems in basalts from site 396B, DSDP, J. Geophys. Res., 86, 7935-7950, 1981.

Bohlke, J.K., J.C. Alt, and K. Muehlenbachs, Oxygen isotope - water relations in altered deep-sea basalts: low-temperature mineralogical controls, Can. J. Earth Sci., 21, 67-77, 1984.

Boles, J.R., Composition, optical properties, cell dimensions and the thermal stability of some heulandite group zeolites, Am. Mineral., 57, 1463-1493, 1972.

Bowers, T.S., and H.P. Taylor, An integrated chemical and stableisotope model of the origin of mid-ocean ridge hot spring systems, J. Geophys. Res., 90, 12,583-12,606, 1985.

Boyle, J.F. and A.H.F. Robertson, Evolving metallogenesis at the Troodos spreading axis, in Ophiolites and Oceanic Lithosphere, edited by I.G. Gass, S.J. Lippard, A.W. Shelton, pp. 169-181, Blackwell Scientific Publications, Oxford, England, 1984.

Brass, G.W., J.R. Southam, and W.H. Peterson, Warm saline bottom water in the ancient ocean, Nature, 296, 620-623, 1982.

Brindley, G.W., and G. Brown, Crystal Structures of Clay Minerals and Their XRD Identification, 495 pp., Mineralogical Society of London, 1980.

Bruland, K.W., Trace elements in seawater, in Chemcial Oceanography, edited by J.P. Riley and R.Chester, pp. 158-220, Academic, San Diego, Calif., 1983.

Chapman, H.J., and E.T.C. Spooner, ${ }^{87} \mathrm{Sr}$ enrichment of ophiolitic sulphide deposits in Cyprus confirms ore formation by circulating seawater, Earth Planet. Sci. Lett., 35, 71-78, 1977.

Clayton, R.N., and T.K. Mayeda, The use of bromine pentafloride in the extraction of oxygen from oxides and silicates for isotopic analysis, Geochim. Cosmochim. Acta, 27, 43-52, 1963.

Cocker, J.D., B.J., Griffin, and K. Muehlenbachs, Oxygen and carbon isotope evidence for seawater-hydrothermal alteration of the Macquarie Island ophiolite, Earth Planet. Sci. Lett., 61, 112-122, 1982.

Coleman, R.G., Ophiolites: Ancient oceanic lithosphere?, SpringerVerlag, 229 pp., New York, 1977.

Constantinou, G., Metallogenesis associated with the Troodos ophiolite, in Ophiolites, Proceedings, International Ophiolite Symposium, Cyprus 1979, edited by A. Panayiotou, pp. 663-674, Cyprus Geological Survey Department, Nicosia, 1980.

Constantinou, G., and G.J.S. Govette, Geology, geochemistry, and genesis of Cyprus sulfide deposits, Econ. Geol., 68, 843-858, 1973.

Coombs, D.S., Cell size, optical properties and chemical composition of laumontite and leonhardite, Am. Mineral., 37, 812-830, 1952.

Cowan, J., and J. Cann, Supercritical two-phase separation of hydrothermal fluids in the Troodos ophiolite, Nature, 333, 259-261, 1988.

Craig, H., Isotopic standards for carbon, oxygen, and correction factors for mass-spectrometric analysis of carbon dioxide, Geochim. Cosmochim. Acta, 12, 133-149, 1957.

Deer, W.A., R.A. Howie, and J. Zussman, Rock Forming Minerals, Longmans Green, and Co. Ltd., Toronto, Ontario, 1962.

Eddy, C.A., and E.M. Moores, Geology, contact relations, and geochemistry of a portion of the sheeted dyke complex, western Mitsero graben, Troodos Ophiolite Complex, Cyprus, Paper presented at Troodos '87: Ophiolites and Oceanic Lithosphere, Cyprus Geological Survey Department, Nicosia, Cyprus, October, 1987.

Edmond, J.M., C. Measures, B. Mangum, B. Grant, F.R. Sclater, R. Collier, A. Hudson, L.J. Gordon, and J.B. Corliss, On the formation of metal-rich deposits at ridge crests, Earth Planet. Sci. Lett., 46, $19-30,1979$.

Elsbree, H.C., Clay alteration in three ore deposits and associated volcanics of the Troodos ophiolite, Cyprus, M.Sc. thesis, 132 pp., Univ. of Illinois, Urbana-Campaign, 1985.

Evarts, R.C., and P. Schiffman, Submarine hydrothermal metamorphism of the Del Puerto ophiolite, Califormia, Am.J. Sci., $283,289-340,1983$.

Friedrichsen, H., Strontium, oxygen, and hydrogen isotope studies on 
primary and secondary minerals in basalts from the Costa Rica Rift, Deep Sea Drilling Project hole 504B, leg 83, Initial Rep. Deep Sea Drill. Proj, 83, 289-295, 1985.

Gass, I., and J.D. Smewing, Intrusion, extrusion, and metamorphism at constructive plate margins: Evidence from the Troodos Massif Cyprus, Nature, 242, 26-29, 1973.

George, R.P., Structural petrology of the Olympus ultramafic complex in the Troodos ophiolite, Cyprus, Geol. Soc. Am. Bull., 89, 845865, 1978.

Gillis, K.M., Multistage alteration of the extrusive sequence, Troodos Ophiolite, Cyprus, Ph.D. thesis, 387 pp., Dalhousie Univ., Halifax, 1987.

Gillis, K.M., and P.T. Robinson, Low-temperature alteration of the extrusive sequence, Troodos ophiolite, Cyprus, Can. Mineral., 23, 431-441, 1985.

Gillis, K.M., and P.T. Robinson, Distribution of alteration zones in the upper oceanic crust, Geology, 16, 262-266, 1988.

Gillis, K.M. and P.T. Robinson, Alteration of the ICRDG CY-1 and CY-1A drillcores: Mineralogical and geochemical studies, Initial Report Cyprus Crustal Study Group, holes CY-1 and CY-1A, Spec. Pap. Geol. Surv. Can. , in press, $1991 a$.

Gillis, K.M., and P.T. Robinson, Multistage alteration of the Troodos ophiolite, Cyprus, in Troodos '87: Ophiolites and Oceanic Lithosphere, edited by E.M. Moores and A. Panayiotou, Cyprus Geological Survey Department, Nicosia, in press, $1991 b$.

Gregory, R.T., and R.E. Criss, Isotopic exchange in open and closed systems, Stable isotopes in high temperature geological processes, Rev. Mineral., 6, 91-129, 1986

Gregory, R.T., and H.P. Taylor, Jr., An oxygen isotope profile of a section of Cretaceous oceanic crust, Samail ophiolite, Oman: Evidence for $\delta^{18} \mathrm{O}$-buffering of the oceans by deep ( $>5 \mathrm{~km}$ ) seawaterhydrothermal circulation at mid-ocean ridges, J. Geophys. Res., 86, 2737-2755, 1981.

Hall, J.M., C. Walls, M. Willamson, and B.-W. Wang, Depth trends in magnetic properties in an area of prolonged cold seawater drawdown in uppermost Troodos-type oceanic crust, Can.J. Earth Sci., 24, 941-952, 1987.

Harper, G.D., J.R. Bowman, and R. Kuhns, A field, chemical, and stable isotope study of subseafloor metamorphism of the Josephine ophiolite, Califomia-Oregon, J. Geophys. Res., 93, 4625-4656, 1988.

Hartland, W.B., A.V. Cox, P.G. Llewellyn, C.A.G. Pickton, A.G. Smith, and R. Walters, A Geologic Timescale, 131 pp., Cambridge University Press, New York, 1982.

Hay, R.L., Zeolites and zeolitic reactions in sedimentary rocks, Spec. Pap.,Geol. Soc. Am., 85, 130 pp., 1966.

Heaton, T.H.E., and R.A. Sheppard, Hydrogen and oxygen isotope evidence for seawater-hydrothermal alteration and ore deposition, Troodos ophiolite, Cyprus, Volcanic processes in ore genesis, Geol. Soc. Spec. Publ. London, 7, pp. 42-57, 1977.

Herzig, P.M., A mineralogical, geochemical, and thermal profile through the Agrokipia "B" hydrothermal sulfide deposit, Troodos ophiolite complex, Cyprus, in Base Metal Sulfide Deposits, pp. 182-215, edited by G.H. Friedrich and P.M. Herzig, Springer-Verlag, New York, 1988.

Herzig, P.M., and G.H. Friedrich, Sulfide mineralization, hydrotherma alteration and chemistry in the drill hole CY-2A, Agrokipia, Cyprus, Cyprus Crustal Study Project Initial Report, holes CY-2 and CY-2A, Geol. Surv. Can. Pap., 85-29, 103-138, 1987.

Hess, J., M. Bender, and J.G. Schilling, Seawater ${ }^{87} \mathrm{Sr} /{ }^{86} \mathrm{Sr}$ evolution from Cretaceous to present, applications to paleoceanography, Science, 231, 979-984, 1986.

Hey, M.H., A new review of the chlorites, Mineral. Mag., 30, $277-$ 292, 1954.

Honnorez, J., Generation of phillipsites by palagonitization of basaltic glass in seawater and the origin of $\mathrm{K}$-rich deep-sea sediments; in Natural Zeolites: Occurrence, Properties, Use, edited by L.B. Sand and F.A. Mumpton, pp. 245-258, Pergamon, New York, 1978.

Honnorez, J., The aging of the oceanic crust at low-temperatures, in The Oceanic Lithosphere, The Sea 7, edited by C. Emiliani, pp. 525588 , John Wiley, New York, 1981.

Honnorez, J., J. Alt, B.M., Honnorez-Guerstein, C. Laverne, K. Muehlenbachs, J. Ruiz, and E. Saltzman, Stockwork-like sulfide mineralization in young oceanic crust: Deep Sea Drilling Project hole 504B, Initial Rep. Deep Sea Drill. Proj., 83, 263--282, 1985.
Horbie, Y., K.-R. Kim, and H. Craig, hydrothermal methane plumes in the Marianas back-arc spreading center, Nature, 324, 131, 1986.

Humphris, S.E., and G. Thompson, Hydrothermal alteration of oceanic basalts by seawater, Geochim. Cosmochim. Acta, 42, 107-125, 1978.

Hurst, S.D., E.M. Moores, and R.J. Varga, The spreading structure of the Solea Graben, Cyprus, Paper presented at Troodos '87: Ophiolites and Oceanic Lithosphere, Cyprus Geological Survey Department, Nicosia, Cyprus, October, 1987.

Iijima, A., and M. Utada, Present-day zeolitic diagenesis of the Neogene geosyncline deposits in the Niigata oil field, Japan, Molecular sieve zeolites, I, Adv. Chem. Ser., 101, 342-349, 1971.

Jones, J.B., and E.R. Segnit, The nature of opal, I, Nomenclature and constituent phases, J. Geol. Soc. Aust., 18, 57-68, 1971.

Knauth, L.P., and S. Epstein, Hydrogen and oxygen isotope ratios in nodular and bedded cherts, Geochim. Cosmochim. Acta, 40, 10951108, 1976.

Kristmannsdottir, H., Hydrothermal alteration of basaltic rocks in Iceland geothermal areas, Paper presented at Proceedings, 2nd U.N. Symposium on the development and use of geothermal resources, San Francisco, Calif., May 20-29, 1975.

Kristmannsdottir, H. and J. Tomasson, Zeolite zones in geothermal areas in Iceland; in Zeolites: Occurrence, Properties, Use, edited by L.B. Sand and F.A. Mumpton, pp. 277-284, Pergamon, New York, 1978.

Liou, J.G., Stilbite-laumontite equilibrium, Contrib. Mineral. Petrol., 31, 171-177, 1971a.

Liou, J.G., Analcime equilibrium, Lithos, 4, 389-402, $1971 b$

Liou, J.G., S. Maruyama, and M. Cho, Phase equilibria and mineral paragenesis of meta-basalts in low-grade metamorphism, Mineral. Mag., 49, 321-333, 1985.

Lydon, J.W., Some observations on the mineralogical and chemical zonation patterns of volcanogenic sulfide deposits of Cyprus, Geol. Surv. Can. Pap. 84-1A, 611-616, 1984.

Machado, N., C. Brooks, and S.R. Hart, Determination of initial ${ }^{87} \mathrm{Sr} /{ }^{86} \mathrm{Sr}$ and ${ }^{143} \mathrm{Nd} /{ }^{144} \mathrm{Nd}$ ratios in primary minerals from mafic and ultramafic rocks: Experimental procedure and implications for the isotopic characteristics of the Archean mantle under the Abitibi greenstone belt, Canada, Geochim. Cosmochim. Acta, 50, 2335 $2348,1986$.

Malahoff, A., G.M. McMurtry, J.C. Wiltshire, and H.-W. Yeh, Geology and chemistry of hydrothermal deposits from active submarine volcano Loihi, Hawaii, Nature, 298, 234-239, 1982.

Malpas, J., and G. Langdon, Petrology of the upper pillow lava suite, Troodos ophiolite, Cyprus, in Ophiolites and Oceanic Lithosphere, pp. 155-167, edited by I.G. Gass, S.J. Lippard, and A.W. Shelton, Blackwell Scientific Publications, Oxford, England, 1984.

Malpas, J.G., T. Calon, and C. Xenophontos, Plutonic rocks of the Troodos ophiolite, in Troodos '87: Ophiolites and Oceanic Lithosphere Symposium Field Excursion Guidebook, Cyprus Geological Survey Department, Nicosia, pp. 158-181, 1987.

Matsuhisa, Y., J.R. Goldsmith, and R.N. Clayton, Oxygen isotopic fractionation in the system quartz-albite-anorthite-water, Geochim. Cosmochim. Acta, 43, 1131-1140, 1979.

Matthews, A., and M. Schliestedt, Evolution of the blueschist and greenschist facies rocks of Sifnos, Cyclades, Greece, Contrib. Mineral. Petrol., 88, 150-163, 1984.

McCrea, J.M., The isotope chemistry of carbonates and a paleotemperature scale, J. Chem. Phys., 18, 849-857, 1950.

McCulloch, M.T., R.T. Gregory, G.T. Wasserburg, and H.P. Taylor, $\mathrm{Jr}$., $\mathrm{Sm}-\mathrm{Nd}, \mathrm{Rb}-\mathrm{Sr}$, and ${ }^{18} \mathrm{O} /{ }^{16} \mathrm{O}$ isotopic systematics in an oceanic crustal section: Evidence from the Samail Ophiolite, J. Geophys. Res., 86, 2721-2735, 1981.

Mehegan, J.M., Temporal, spatial, and chemical evolution of the Troodos ophiolite lavas, Cyprus: Supra-subduction zone volcanism in the Tethys Sea, Ph.D. thesis, Dalhousie Univ., Halifax, Nova Scotia, 1988.

Mehegan, J., and P.T. Robinson, Lava compositions of the Troodos ophiolite, Cyprus, Eos Trans. AGU, 66, 1123, 1985.

Michard, G., F. Albarede, A. Michard, J.-F. Minster, J.-L. Charlou, and N. Tan, Chemistry of solutions from the $13^{\circ} \mathrm{N}$ East Pacific Rise hydrothermal site, Earth Planet. Sci. Lett., 67, 297-307, 1984.

Miyashiro, A., The Troodos ophiolite complex was probably formed in an island arc, Earth Planet. Sci. Lett., 19, 218-224, 1973.

Moores, E.M., and F.J. Vine, The Troodos massif, Cyprus and other 
ophiolites as oceanic crust: Evaluation and implications, Philos. Trans. R. Soc. London, Ser. A, 268, 443-466, 1971.

Moores, E.M., P.T. Robinson, J. Malpas, and C. Xenophontos, A model for the origin of the Troodos Massif, Cyprus and other mideast ophiolites, Geology, 12, 500-503, 1984.

Mottl, M.J., Metabasalts, axial hot springs, and the structure of hydrothermal systems at mid-ocean ridges, Geol. Soc. Am. Bull., 89, 161-180, 1983.

Mottl, M.J., and H.D. Holland, Chemical exchange during hydrothermal alteration of basalt by seawater, 1, Experimental results for major and minor components of seawater, Geochim. Cosmochim. Acta, 42, 1103-1115, 1978.

Mottl, M., and W.E. Seyfried, Subseafloor hydrothermal systems: Rock- versus seawater dominated, in Seafloor Spreading Centers,: Hydrothermal systems, edited by P.A. Rona, and R. Lowell, pp. 6682, Dowden, Hutchinson, and Ross, Stroudsburg, Pa., 1980.

Muehlenbachs, K., The alteration and aging of the basaltic layer of the seafloor: Oxygen isotope evidence from DSDP/IPOD legs 51, 52, and 53, Initial Rep. Deep Sea Drill. Proj., 51-53, part 2, 1159-1167, 1979.

Muehlenbachs, K., Alteration of the ocean crust and the ${ }^{18} \mathrm{O}$ history of seawater, Rev.n Mineral., 6, 425-445, 1986.

Muehlenbachs, K., and R.N. Clayton, Oxygen isotope composition of the oceanic crust and its bearing on seawater, J. Geophys. Res., 81, 4365-4369, 1976.

Mukasa, S.B., and J.N. Ludden, Uranium-lead isotopic ages of plagiogranites from the Troodos ophiolite, Cyprus, and their tectonic significance, Geology, 15, 825-828, 1987.

Mumpton, F.A., Clinoptilolite redefined, Am. Mineral., 45, 351-369, 1960.

Munha, J., W.S. Fyfe, and R. Kerrich, Adularia, the characteristic mineral of felsic spilites, Contrib. Mineral. Petrol., 75, 15-19, 1980.

Nehlig, P., and T. Juteau, Deep crustal seawater penetration and circulation at ocean ridges: Evidence from the Oman ophiolite, Mar. Geol., 84, 209-228, 1988.

Norton, D.L., Theory of hydrothermal systems, Annu. Rev. Earth Planet. Sci., 12, 155-177, 1984.

O'Neil, J.R., R.N. Clayton, and J.K. Mayeda, Oxygen isotope fractionation in divalent metal carbonates, J. Chem. Phys., 51, 5547-5558, 1969.

Oudin, E. and G. Constantinou, Black smoker chimney fragments in Cyprus sulfide deposits, Nature, 308, 349-353, 1984.

Rautenschlein, M., G. Jenner, J. Hertozen, A.H. Hofmann, R. Kerrich, H.-U. Schmincke, and W.M. White, Isotopic and trace element composition of volcanic glass from the Akaki Canyon, Cyprus: Implications for the origins of the Troodos ophiolite, Earth Planet. Sci. Lett., 75, 369-383, 1985.

Richards, H., J.R. Cann, and J. Jensenius, Mineralogical zonation and metasomatism of the alteration pipes of Cyprus sulfide deposits, Econ. Geol., 84, 91-115, 1989.

Richardson, C.J., J.R. Cann, H.G. Richards, and J.G. Cowan, Metaldepleted root zones of the Troodos ore-forming hydrothermal systems, Cyprus, Earth Planet. Sci. Lett., 84, 243-253, 1987.

Richardson, S.H., S.R. Hart, and H. Staudigel, Vein mineral ages of old oceanic crust, J. Geophys. Res., 85, 7195-7200, 1980.

Robertson, A.H.F., Tertiary uplift history of the Troodos massif, Cyprus, Geol. Soc. Am. Bull., 88, 1763-1772, 1977.

Robinson, P.T., W. Melson, and H.-U. Schmincke, Volcanic glass compositions of the Troodos ophiolite, Cyprus, Geology, 11, 400404, 1983.

Robinson, P.T., I.L. Gibson, and A. Panayiotou, Cyprus Crustal Study Project initial report, holes CY-2 and CY-2A, Geol. Surv. Can. Pap., 85-29, 381 pp., 1987.

Robinson, P.T., I.L. Gibson, and A. Panayiotou, Cyprus Crustal Study Project initial report, holes CY1 and CY1A, Geol. Surv. Can. Pap., in press, 1991.

Rommel, U., and H. Friedrichsen, The alteration chemistry of CCSP hole CY-2a: A stable and radiogenic study, Cyprus Crustal Study Project, initial report, holes CY-2 and CY-2A, Geol. Surv. Can. Pap., 85-29, pp. 169-181, 1987.

Rosenbauer, J.R., and J.L. Bischoff, Uptake and transport of heavy metals by heated seawater: A summary of the experimental results, in Hydrothermal Processes at Seafloor Spreading Centers, edited by P.A. Rona, K. Bostrom, L. Laubier, and K.L. Smith, Jr., pp. 177 198, Plenum, New York, 1983.
Ross, C.S., and S.B. Hendricks, Minerals of the montmorillonite group: Their origin in relation to soils and clays, Geol. Surv. Prof. Pap., 205B, 23-79, 1945.

Savin, S.M., The history of the earth's surface temperature during the past 100 million years, Annu. Rev. Earth Planet. Sci., 5, 319-355, 1977.

Schiffman, P., and B.M. Smith, Petrology and oxygen isotope geochemistry of a fossil seawater hydrothermal system within the Solea Graben, northern Troodos ophiolite, Cyprus, J. Geophys. Res., 93, 4612-4624, 1988.

Schiffman, P., B.M. Smith, R.J. Varga, and E.M., Moores, Geometry, conditions and timing of off-axis hydrothermal metamorphism and ore deposition in the Solea graben, Nature, 325, 423-425, 1987.

Schmincke, H.-U., M. Rautenschlein, P.T. Robinson, and J.M. Mehegan, Troodos extrusive series of Cyprus: A comparison with oceanic crust, Geology, 11, 405-409, 1983.

Seewald, J.S., $\mathrm{Na}$ and $\mathrm{Ca}$ metasomatism during hydrothermal basalt alteration: An experimental and theoretical study, M.Sc. thesis, Univ. of Minnesota, Minneapolis, 1987.

Seyfried, W.E., Jr., Experimental and theoretical constraints on hydrothermal alteration processes at mid-ocean ridges, Annu. Rev. Earth Planet. Sci. Lett., 15, 317-335, 1987.

Seyfried, W.E., Jr., and J.L. Bischoff, Hydrothermal transport of heavy metals by seawater: The role of seawater/basalt ratio, Earth Planet. Sci. Lett., 34, 71-77, 1977.

Seyfried, W.E., Jr., W.C. Shanks III, and W.E. Dibble, Jr., Clay mineral formation in DSDP leg 34 basalt, Earth Planet. Sci. Lett. 41, 265-276, 1978.

Seyfried, W.E., Jr., D.R. Janecky, and M. Mottl, Alteration of the oceanic crust: Implications for geochemical cycles of lithium and boron, Geochim. Cosmochim. Acta, 48, 557-569, 1984.

Seyfried, W.E., Jr., M.E. Berndt, and J.S. Seewald, Hydrothermal alteration processes at mid-ocean ridges: Constraints from diabase alteration experiments, hot-spring fluids, and composition of the oceanic crust, Can. Mineral., 26, 787-804, 1988.

Shipboard Scientific Crew, Legs 51-53, Sites 417 and 418, Initial. Rep. Deep Sea Drill. Proj., 51-53, 23-626, 1979.

Spooner, E.T.C., H.J. Chapman, and J.D. Smewing, Strontium isotopic contamination and oxidation during ocean floor hydrothermal metamorphism of the ophiolitic rocks of the Troodos Massif, Cyprus, Geochim. Cosmochim. Acta, 41, 873-890, 1977.

Stakes, D.S., and J.R. O'Neil, Mineralogy and stable isotope geochemistry of hydrothermally altered oceanic rocks, Earth Planet. Sci. Lett., 57, 285-304, 1982.

Staudigel, H., and K.M. Gillis, The timing of hydrothermal alteration in the Troodos ophiolite, in Troodos '87: Ophiolites and Oceanic Lithosphere, edited by E.M. Moores and A. Panayiotou, Cyprus Geological Survey Department, Nicosia, in press, 1991.

Staudigel, H., and S.R. Hart, Dating of ocean crust alteration: Strontium isotopic ratios from 504B carbonates and a reinterpretation of $\mathrm{Sr}$ isotopic data from DSDP sites $105,332,417$, and 418, Initial Rep. Deep Sea Drill. Proj., 83, 297-303, 1985.

Staudigel, H., S.R. Hart, and S.H. Richardson, Alteration of the oceanic crust: Processes and timing, Earth Planet. Sci. Lett., 52, 311-327, 1981.

Staudigel, H., K. Gillis, and R. Duncan, $\mathrm{K} / \mathrm{Ar}$ and $\mathrm{Rb} / \mathrm{Sr}$ ages of celadonites fom the Troodos ophiolite, Cyprus, Geology, 14, 72 $75,1986$.

Stern, C., and D. Elthon, Vertical variations in the effects of hydrothermal metamorphism in Chilean ophiolites: Their implications for ocean floor metamorphism, Tectonophysics, 55, 179-213, 1979.

Sunkel, G., U. Bednarz, and H.-U. Schmincke, The basaltic andesiteandesite and the andesite-dacite series from the ICRDG drill holes CY-2 and CY-2A. II. Alteration, in Cyprus Crustal Study Project, initial report, holes $C Y-2$ and $C Y-2 A$, edited by P.T. Robinson, I.L. Gibson, and A. Panayiotou, Geol. Surv. Can. Pap., 85-29, 205-219, 1987.

Thompson, G., Basalt-seawater interaction, in Hydrothermal Processes at SeafloorSpreading Centers, edited by P.A. Rona, K. Bostrom, L.Laubier, and K.L. Smith, pp. 225-278, Plenum, New York, 1983.

Thy, P., C.K. Brooks, and J.N. Walsh, Tectonic and petrogenic implications of major and rare earth element chemistry of Troodos glasses, Cyprus, Lithos, 18, 165-178, 1985.

Varga, R.J., and E.M. Moores, Spreading structure of the Troodos ophiolite, Cyprus, Geology, 13, 846-850, 1985. 
Von Damm, K.L., Systematics of and postulated controls on submarine hydrothermal solution chemistry, J. Geophys. Res., 93, 4551$4561,1988$.

Von Damm, K.L., J.M. Edmond, B. Grant, C.I. Measures, B. Walden, and R.F. Wiess, Chemistry of submarine hydrothermal solutions at $21^{\circ}$ N, East Pacific Rise, Geochim. Cosmochim. Acta, 49, 1031$1083,1985$.

Wenner, D.B., and H.P. Taylor, Jr., Temperatures of serpentinization of ultramafic rocks based on ${ }^{18} \mathrm{O} /{ }^{16} \mathrm{O}$ fractionation between coexisting serpentine and magnetite, Contrib. Mineral. Petrol., 32, $165-185,1971$.

Wise, W.S., and H.P. Eugster, Celadonite: Synthesis, thermal stability and occurrence, Am. Mineral., 49, 1031-1083, 1964.

Yeh, H.-W., and S.M. Savin, Mechanism of burial metamorphism of argillaceous sediments, 3, O-isotope evidence, Geol. Soc. Am. Bull., 88, 1321-1330, 1977.
Zierenberg, R.A., W.C. Shanks III, W.E. Seyfried, Jr., R.A. Koski, and M. D. Strickler, Mineralization, alteration, and hydrothermal metamorphism of the ophiolite-hosted Turner-Albright sulfide deposit, southwestern Oregon, J. Geophys. Res., 93, 4657-4674, 1988.

K.M. Gillis and P.T. Robinson, Department of Geology and Center of Marine Geology, Dalhousie University, Halifax, Nova Scotia, Canada B3H 3J7.
(Recieved March 2, 1989;

revised September 19, 1989; accepted March 30, 1990). 